University of Rhode Island

DigitalCommons@URI

Open Access Master's Theses

1992

\title{
A Study of the Providence Historic District Commission
}

Pheamo R. Witcher

University of Rhode Island

Follow this and additional works at: https://digitalcommons.uri.edu/theses

\section{Recommended Citation}

Witcher, Pheamo R., "A Study of the Providence Historic District Commission" (1992). Open Access Master's Theses. Paper 742.

https://digitalcommons.uri.edu/theses/742

This Thesis is brought to you for free and open access by DigitalCommons@URI. It has been accepted for inclusion in Open Access Master's Theses by an authorized administrator of DigitalCommons@URI. For more information, please contact digitalcommons-group@uri.edu. 


\begin{abstract}
A STUDY OF THE
PROVIDENCE HISTORIC DISTRICT COMMISSION
\end{abstract}

BY

PERAYO R. WITCEER

A RESEARCE PROJECT SUBMITTED IN

PARTIAL FULFILIMENT OF TEE REQOIREMENTS

FOR THE DEGREE OF

MASTER OF COMMUNITY PIANNING AND AREA DEVELOPMENT

1992 
MASTER OT COMMUNITY PLANNING AND AREA DEVELOPMENT RESEARCH PROJECT

Or PHEAMO R. PITCHER

Approved:

Major Professor

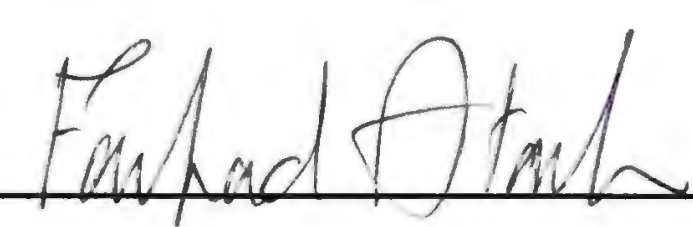

Acknowledged

Director Marie Mule 7 dele 


\section{ABSTRACT}

A Study of the Providence Historic District Commission is a comprehensive analysis of the Commission and the city of Providence's seven local historic districts. The study examines the rules, regulations and scope of the Commission and documents in detail the design review guidelines which the Commission utilizes. Additionally, profiles of the city's seven historic districts are presented to document their location, historical pattern of development and unifying elements. A section pertaining to owners of historic properties is another integral component of this study. This section serves to inform and to assist property owners in understanding what historic district zoning is and what it is not. Finally, findings and recommendations are presented to assist the commission in regulating the local historic districts. 


\section{ACRONTIRDGEMENTS}

I would like to express my sincere gratitude to all those individuals who have carefully guided me through this research project, particularly Dr. Atash, Kathryn Cavanaugh, Mary P. Turkel and Marjorie Jensen. These individuals graciously answered questions and read the many drafts of this project and offered timely advice. Additionally, I would like to thank those individuals who contributed to this project by completing a survey or allowing me to interview them. 


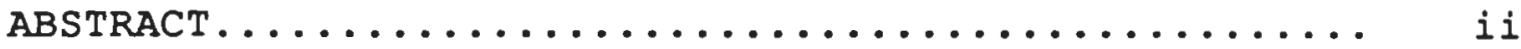

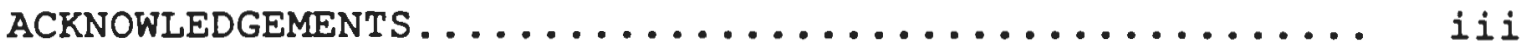

TABLE OF CONTENTS......................... iv

IIST OF FIGURES............................ vi vi

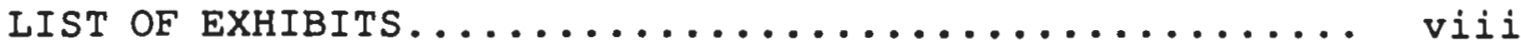

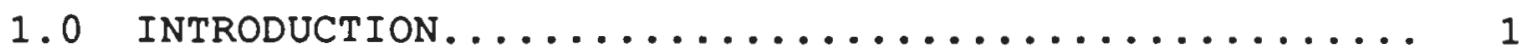

1.1 Background and Significance of the Study....... 2

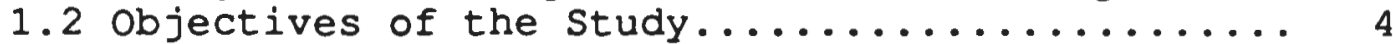

1.3 scope and Content of the study.............. 5

1.4 Methods of Analysis...................... 6 1.4.1 Overview of Relevant Current Literature 7

2.0 THE PROVIDENCE HISTORIC DISTRICT COMMISSION...... 12

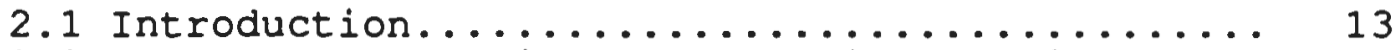

2.2 What Is the Providence Historic District......

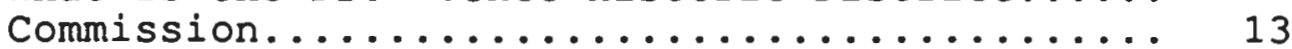

2.3 Legal Basis of the Commission.............. 14 2.3.1 State Enabling Legislation............ 14

2.3.2 City Enabling Legislation............... 15

2.4 Composition of the Commission............. 16

2.5 Organization of the Commission............. 17

2.6 Scope and Powers of the Commission........... 20

2.7 Commission Operating Rules and Procedures..... 22

3.0 THE LOCAL HISTORIC DISTRICTS................. 26

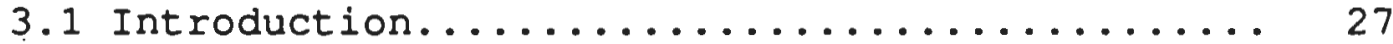

3.2 What is a Local Historic District........... 27

3.3 Creation of Local Historic Districts......... 28

3.4 The Local Historic Districts.............. 31

The College Hill Historic District.......... 33

The Stimson Avenue Historic District........ 36

The Broadway Historic District............ 38

The Armory Historic District............. 40

The South Elmwood Historic District......... 43

The Downtown Historic District........... 46

The North Elmwood Historic District........ 53

4.0 DESIGN REVIEW GUIDELINES................... 55

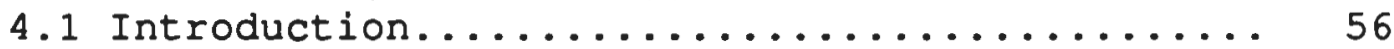

4.2 What Are Design Review Guidelines........... 57

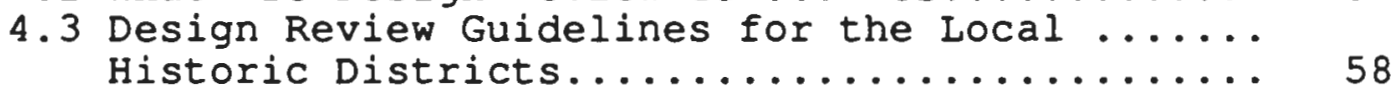

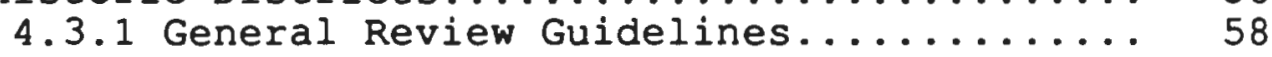

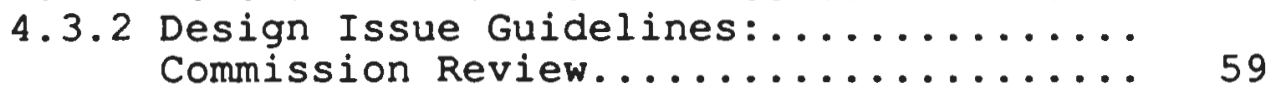

Commission Review............................. 59

B. Alterations/Minor Modifications...... 64 
C. Moving of Historic Structures...... 66

D. Signage................... 69

4.3.3 Design Issue Guidelines:Staff Review... 71

A. Awnings................. 72

B. Shutters and Blinds............ 73

C. Site Improvements/Driveways/Walkways. 74

D. Storm windows and Doors........... 75

E. In-Kind Replacement/Repairs....... 77

F. Fences/Gates................. 78

G. Chillers/Condensing Units......... 79

H. Roofs/Gutters/Downspouts......... 80

4.3.4 Items Exempt from Review.......... 81

4.3.5 District Specific Guidelines........ 83

5.0 THE PROPERTY OWNER..................... 84

5.1 Introduction........................ 85

5.2 What Does Historic District Designation Mean to You: The Property Owner............... 86

5.3 What is A Certificate of Appropriateness and the Procedures for Applying for one....... 87

5.4 The Public Hearing Procedures and Process..... 88

5.5 How Decisions of the Commission Are Conveyed.. 90

5.6 How to Appeal a Decision of the Commission.... 91

6.0 RESOURCES AND AGENCIES................. 93

6.1 Introduction...................... 94

6.2 Preservation Resources................. 95

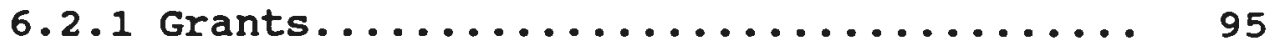

6.2 .2 Revolving Loan Funds............. 95

6.2 .3 Tax Incentives................. 96

6.2 .4 Loan Programs.................. 96

6.2.5 Educational and Technical Assistance... 97

6.3 The Preservation Network............... 97

6.3.1 Federal Agencies and Organizations..... 98

6.3 .2 State Agencies................. 99

6.3 .3 City Agencies..................... 100

6.3 .4 Local Preservation Agencies.......... 100

6.3 .5 Other organizations.............. 103

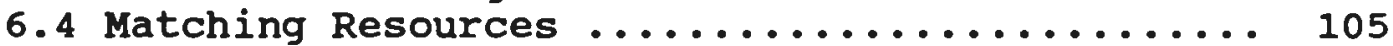

6.4.1 Matching Resources Matrix........... 105

7.0 ENHANCING PRESERVATION ACTIVITIES: FINDINGS AND ...

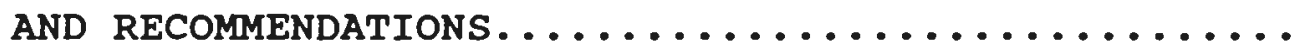

7.1 The Introduction...................... 108

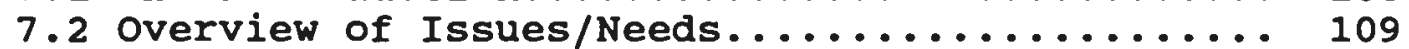

7.3 Implementation Strategies.............. 111 
REFERENCES.............................. 127

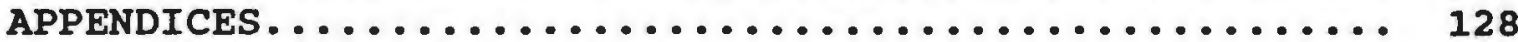

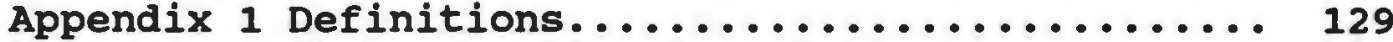

Appendix 2 State Enabling Legislation........... 136

Appendix 3 City Enabling Legislation............ 143

Appendix 4 Inventory of Architectural styles..... 152

Appendix 5 Agency survey Form................ 162

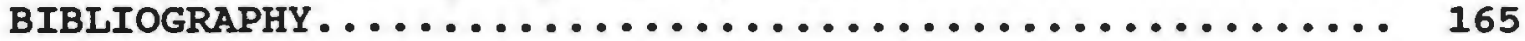




\section{IIST OF FIGURES}

PAGE

FIGURE

1. ORGANIZATIONAL CHART OF PLANNING DIVISION OF THE.. PROVIDENCE DEPARTMENT OF PLANNING AND DEVELOPMENT.

2. LOCAL HISTORIC DISTRICT DESIGNATION PROCESS ..... 30

3. MAP OF THE LOCAL HISTORIC DISTRICTS............ 32

4. MAP OF THE COLLEGE HILL HISTORIC DISTRICT....... 35

5. MAP OF THE STIMSON AVENUE HISTORIC DISTRICT...... 37

6. MAP OF THE BROADWAY HISTORIC DISTRICT........... 39

7. MAP OF THE ARMORY HISTORIC DISTRICT........... 42

8. MAP OF THE SOUTH ELMWOOD HISTORIC DISTRICT....... 45

9. MAP OF THE DOWNTOWN DISTRICTS...............49

10. MAP OF THE DOWNTOWN HISTORIC DISTRICT (ZONE 1) ... 50

11. MAP OF THE DOWNTOWN HISTORIC DISTRICT (ZONE 2) ... 51

12. MAP OF THE DOWNTOWN HISTORIC DISTRICT (ZONE 3) ... 52

13. MAP OF THE NORTH ELMWOOD HISTORIC DISTRICT....... 54

14. ACTION STRATEGY FOR PRESERVATION............. 112 


\section{IIST OF EXHIBITS}

PAGE

Exhibit One:

Exhibit Two:

Exhibit Three:

Exhibit Four:

Exhibit Five:

Exhibit Six:

Exhibit Seven:
Questions and Answers for Local

Historic Districts............ 117

Questions and Answers for Local

Historic Districts............. 119

Graphic Illustrations.......... 121

Graphic Illustrations........... 122

Graphic Illustrations.......... 123

Graphic Illustrations.......... 124

Graphic Illustrations.......... 125 
1.0 INTRODOCTION 


\subsection{BACKGROUND AND SIGNIFICANCI OF THE STUDY}

The preservation of architecturally and historically significant buildings has been and continues to be an integral component of the City of Providence's plans for future growth and development. These structures contribute to Providence's rich historic and cultural legacy, a legacy which many feel should be proactively preserved. This study is being completed as one aspect of the City's overall program to preserve and protect this legacy. The study is designed to accomplish this objective by 1) explaining the role, purpose and operating procedures of the Providence Historic District Commission, the PHDC or HDC (herein after referred to as the Commission); 2) serving as a reference and resource tool for owners of historic properties.

Providence 2000: The Comprehensive Plan (1992:75) indicates that the historic preservation movement in the City was initiated by various local non-profit organizations. Organizations such as the Providence Preservation Society (PPS), established in 1956, were formed to discourage the widespread demolition of the City's historic fabric, which was a result of the various Urban renewal projects taking place in the City in the 1950's.

In 1956, the Providence Redevelopment Agency and PPS joined forces to apply for a federal pilot grant to explore ways to protect the architecturally and historically 
significant structures of the College Hill Area. Through this pilot grant, the landmark report entitled college Hi11: A Demonstration Study of Historic Area Renewal was completed. This study laid the framework for historic preservation activities in the City. It made many recommendations which enhanced historic preservation activities in the City including the establishment of historic district zoning and the creation of a Historic District Commission to regulate the City's local historic districts.

Today, the City of Providence utilizes historic district zoning for the following purposes:
a) To safeguard the heritage of the City by preserving designated districts and structures of historic or architectural value, which reflect elements of Providence's cultural, social, economic, political, and architectural history;
b) to stabilize and improve property values in such district or designated structures;
c) to maintain and foster civic beauty;
d) to strengthen the economy; and
e) to promote the use of designated districts and structures for the education, pleasure and welfare of the citizens.

Thus, a study of the Commission and the City's local historic districts is significant because: 1) it can be used by the Commission and the City to improve and enhance preservation activities; 2) it can serve as a model for other communities and organizations who wish to create 
handbooks for their local historic districts and the Commissions that regulate them; 3 ) it can be used as an educational tool, one that can be used to teach interested parties about historic preservation activities; and 4) it can be used to improve communication between the Commission and owners of historic properties.

\subsection{OBJECTIVES OF THR STUDY}

This study is being completed to answer a number of important questions concerning the preservation of Providence's rich historic resources. The questions that will be answered include the following:

1. Why is historic preservation important to the City of Providence?

2. What is the Providence Historic District Commission and what are its responsibilities, obligations and powers?

3. How are local historic districts established and how are properties identified as architecturally and/or historically significant ?

4. What does historic district designation mean to a property owner ? What are the obligations of a owner of a designated property ?

5. What are the available resources and tools for historic preservation in the City of Providence?

6. Who are the key players and actors in historic preservation in the City of Providence ? What organizations and individuals are involved in historic preservation? 


\subsection{SCOPE AND CONTENT OY THE STUDY}

The scope of this study is limited to the Providence Historic District Commission and the local historic districts regulated by the Commission. As a result, the study does not chronicle the history of the national preservation movement or preservation activities in other cities. The study contains six chapters which collectively explain the role of the Providence Historic District Commission and offer assistance and guidance to owners of historic properties.

Chapter One, lays down the framework of the report. It documents the purpose, process and methods of development of the handbook. Major questions to be addressed and a review of relevant current literature is also included in this chapter.

Chapter Two is an examination of the legal basis upon which historic district zoning and the Providence Historic District Commission was created. The composition, qualifications, terms and responsibilities, as well as the scope and powers of the Providence Historic District Commission are examined.

Chapter Three is an in-depth analysis of the City of Providence's local historic districts delineating the boundaries and locations of these districts and explaining how and why these districts were developed. 
Chapter Four focuses on the design review guidelines of the Historic District Commission, including general review guidelines, issue-specific guidelines and district specific guidelines.

Chapter Five is concerned with explaining what historic district designation means to a property owner. This chapter primarily consists of one-page fact sheets which cover topics such as: what does historic district designation mean to you: the property owner; what is a certificate of appropriateness and how to apply for one; the public hearing procedures and process; and appealing a decision of the Historic District Commission.

Chapter Six is a resource/reference guide for owners of historic properties. Resources, tools and agencies that can assist property owners in maintaining and improving their historic properties are identified in this chapter.

Finally, Chapter Seven identifies and evaluates the strengths and weaknesses of the Commission. Conclusions and recommendations are then made to assist the Commission in meeting its mandate.

\subsection{METHODS OF ANALYSIS}

This study was developed over a three-month period. The impetus for the development of this study was a recommendation contained within A Plan For Preservation.Preliminary research and data collection for the development 
of this handbook began in January 1992 with a review of relevant books, articles, and reports concerning the creation and importance of local historic districts. A review of the current zoning ordinance for the city of Providence, legislation enacting historic district zoning and the rules and regulations of the Providence Historic District Commission was completed at this time.

In early February 1992 a number of individuals and organizations were interviewed to determine the nature and extent of historic preservation activities in the local historic districts and the resulting impact of these activities on owners of historic properties. Additionally, a survey was mailed to individuals and organizations concerned with historic preservation in the City of Providence to identify and categorize resources and tools available to aid property owners in maintaining their historic structures. Windshield surveys of the local historic districts were also conducted to gain an understanding of the character and identity of each district. Finally, a number of Historic District Commission public hearings were attended to view the operating procedures of the Commission first-hand.

\subsubsection{Overview of Relevant Current Literature}

Most of the literature reviewed has assisted the researcher in answering the major questions to be addressed, 
as indicated in the objectives of the study. The principal research questions have been restated throughout this discussion of relevant current literature to ensure consistency and clarity in indicating how each source has aided the researcher in completing this project.

Question 1: Why is historic preservation important? What is its importance to Providence?

A number of sources addressed the importance of historic preservation, including the landmark report with Heritage So Rich, Design Review in Historic Districts, and $\underline{A}$ Handbook on Historic Preservation Law. Each of these sources presented a historical overview of historic preservation at the federal, state and local levels and explained why historic preservation has been and continues to be important.

Additional documents which addressed this question include Providence 2000: The Comprehensive Plan, and A Plan For Preservation. Furthermore, these documents established important City goals and objectives for preservation. For instance, A Plan For Preservation, explained the importance and value of preservation to the City with the following statement:

The value of Preservation in Providence can be measured both in substantive and objective terms. Safeguarding the City's heritage enriches its quality of life, fosters civic pride, and enhances an understanding of the city's past and future (Buckhurst Fish Hutton Katz 1991:1). 
Question 2: What is the Providence Historic District Commission and what are its responsibilities, obligations and powers?

The City's recently completed zoning Ordinance and the City of Providence Certified Local Government Program Annual Report 1990-1991 explained the organization, the purpose and the scope of the Historic District Commission. Additionally, the Operating Rules and Regulations of the Providence Historic District Commission are covered in detail in these documents.

Question 3: How are local historic districts established and how are properties identified as architecturally and/or historically significant ?

Two sources documented how historic districts are established. The first is A Guide to Delineating Edges of Historic Districts which explained how cities determine where a local historic district will begin and end. It discussed the factors that cities use in their evaluation. Additionally, it presented case studies of how local historic district boundaries were determined within twenty local historic districts in the United States. The second source, A Plan for Preservation, explained how local historic districts were established in the City of Providence. It laid out the specific actions and activities that were undertaken in creating these districts. 
Question 4: What does historic district designation mean to a property owner? What are the obligations of an owner of a designated property ?

The City of Providence Zoning Ordinance summarized the obligations and responsibilities of property owners in local historic districts. It briefly explained how historic district designation impacted a property owner in terms of what an owner could and could not do to a property located within a local historic district.

Question 5: What are the available resources and tools for historic preservation in the City of Providence?

A Plan for Preservation provided a comprehensive listing of administrative, regulatory, financial and educational tools that can be used for historic preservation purposes. Additional information as to available resources and tools for historic preservation in the City of Providence was contained in the South Providence and Elmwood Neighborhood Conservation Strategies Report. This report also contained an inventory of individuals and organizations involved in historic preservation. Arthur Ziegler's, Historic Preservation in Inner City Areas, contained a significant amount of information pertaining to available resources to preserve historic homes in inner city areas. Resources examined by ziegler included preservation 
revolving funds, loans and sweat equity.

Question 6: Who are the key players and actors in historic preservation in the City of Providence? What organizations and individuals are involved in historic preservation ?

The South Providence and Elmwood Neighborhood

Conservation Strateqies Report inventoried organizations that were involved in historic preservation in the City of Providence by listing the name, address, phone number, founding date of organization and the types of services offered. This inventory was used by the researcher as a starting point in identifying organizations and community groups involved in preservation-related activities. 
2.0 THE PROVIDENCE HISTORIC DISTRICT COMMISSION 


\subsection{INTRODUCTION}

This chapter examines the Commission in detail. It begins by explaining what is the Historic District Commission and the legal basis upon which the Commission was created. Additional aspects of the Commission are examined including the composition, organization, scope and powers, operating rules, regulations and procedures of the Commission. The intent of this chapter is to provide an overview of those aspects of the Commission that have a direct impact how the Commission contributes to the preservation of architecturally, historically and culturally significant buildings throughout the City, through the regulation of the local historic districts.

\subsection{WHAT IS THE PROVIDENCE HISTORIC DISTRICT COMMISSION}

The Providence Historic District Commission (PHDC) is a thirteen member commission whose primary purpose is to preserve and protect the City's vast historic resources through the regulation of the City's local historic districts. The commission is authorized to regulate the construction, demolition, repair, moving and change to the exterior of any structure and/or its appurtenances within any local historic district, identified on the Providence overlay zoning district maps (City of providence zoning Ordinance 1991:39). 
The Commission regulates these activities through the issuance or non-issuance of a Certificate of Appropriateness. A Certificate of Appropriateness is the certificate issued to a property owner by the Historic District Commission upon approval of an owner's request to make exterior changes to his or her historic property. This certificate is required for any change which affects the exterior appearance of a structure or its appurtenances located in a historic district, including construction, alteration, repair, moving or demolition.

Additionally, the Commission adopts and publishes guidelines and standards, as necessary, to inform historic district residents, property owners, and the general public of those criteria by which the Historic District Commission may issue a Certificate of Appropriateness.

\subsection{LEGAL BASIS OF THE COMMISSION}

The legal basis upon which the Providence Historic District Commission was created is twofold: State enabling legislation and City enabling legislation, namely the City of Providence Zoning Ordinance.

\subsubsection{State Enabling Leqislation}

In 1959, the State of Rhode Island approved enabling legislation that authorized cities and towns to enact historic district zoning. The legislation specifically 
stated that:

the preservation of structures of historic and architectural value is hereby declared to be a public purpose and the city Council of any City and the Town Council of any Town shall have the power by ordinance to regulate the construction, alteration, repair, moving and demolition of such structures within the units of such city or Town (Rhode Island General Laws 45-24.1-3).

The legislation additionally authorized Cities and Towns to create commissions to regulate these historic zoning districts. R.I.G.L. outlines the establishment of the commissions:

In order to carry out the purpose of this chapter the city Council of any city or the Town Council of any town shall have the authority to create a Commission to be called the Historic District Commission (R.I.G.L. 45-24.1-3).

Finally, the legislation outlines the obligations and powers of the Commissions in R.I.G.L. 45-24.1-4:

The Commission shall, within (12) months of the date the local historic district zoning ordinance takes effect (a) adopt and publish all rules and regulations necessary to carry out its functions under the provisions of this chapter; and (b) publish such standards as necessary to inform historic district residents, property owners and the general public of those criteria by which the Commission shall determine whether to issue a Certificate of Appropriateness.

\subsubsection{City Enabling Leqislation}

In 1960, the City of Providence established historic district zoning and the Providence Historic District 
Commission through enabling legislation. According to Article V, Section 501 of the City of Providence zoning Ordinance (1991:43):

The Providence Historic District Commission shall have the authority to regulate the construction, alterations, repair, demolition, and, moving of any structure or appurtenance which results in a change to the exterior of the structure and/or appurtenance within any Historic District in the City, as designated in accordance with the Providence zoning Ordinance and shown on the Official Zoning Map.

\subsection{COMPOSITION OF THR COMISSION}

The Providence Historic District Commission is made up of thirteen individuals from the City of Providence, nine of whom are appointed by the Mayor, two of whom are elected from the ranks of the City Council and two are elected from the General Assembly.

All Commission members must have a demonstrated interest in historic preservation. According to section 501 of the Providence Zoning Ordinance (1991:39), Commission members may be drawn from a number of professions, including but not limited to, American History, architectural history, landscape design, law, real estate, planning or historic building contracting. Commission members generally serve a term of three years, however, those elected from the ranks of the City Council serve four years. In the event of vacancy on the Historic District Commission, the appointing 
authority has the authority to make an interim appointment to fill the unexpired term.

\subsection{ORGANIZATION OF THE COMMISSION}

The Historic District Commission consists of the following organizational structure as permitted by Article v, Section 501 of the Providence zoning Ordinance and R.I.G.L. 45-24.1-3, a Chair, Vice Chair, Deputy Vice Chair, and ten other members. In addition, the Commission is provided with professional staff to take care of the day to day operations of the Commission (Providence Historic District Commission 1991:b 1-10). The duties and responsibilities of the Chair, Vice Chair, the Deputy Chair and the staff are indicated as follows:

Chair - The Chair of the Historic District Commission is appointed by the Mayor. The Chair presides over all Commission meetings and is responsible for ensuring that procedures and policies are followed, unless otherwise directed by a majority vote of Commission members present at the session in progress.

Additionally, the Chair has the authority to appoint Commission members to committees to investigate any and all matters brought before the Historic District Commission.

Vice Chair - The Vice Chair is elected from the ranks of Commission members, by majority vote, and is eligible for re-election. The Vice Chair presides over Commission meetings in the absence of the chair, and in this capacity, the vice chair has the same responsibilities, duties and powers of the Chair.

Deputy Vice Chair - The Deputy Vice Chair is elected in 
the same manner as the Vice Chair, and is also eligible for re-election. The Deputy Vice Chair has the same powers, obligations and duties of the Chair in the absence of both the Chair and the Vice Chair.

Staff - Staff is supplied to the Historic District Commission from the Planning Division of the Department of Planning and Development. Figure 1 is an organizational chart of the Department, which clearly shows how the Historic District Commission fits within the overall planning framework of the agency. The staff as indicated above is primarily responsible for the day to day operations of the Commission and in this capacity the staff performs the following activities:

- Performs all clerical functions, including conducting and coordinating all HDC correspondence and maintains all records of the Commission;

- Acts as a liaison between the Commission and all departments and organizations which relate to the conduct of the HDC affairs;

- Informs applicants, property owners and others of the rules, regulations, operating procedures and standards of the Providence Historic District Commission through consultation and other means.

- Conducts in-house staff approvals for applications for Certificates of Appropriateness for in-kind replacement and repairs and other items.

- Completes written analyses of applications pending for Certificates of Appropriateness. These analyses include a review of the historical and architectural significance of the properties, consistency of the proposals with the standards and guidelines of the Commission, preservation issues and other matters deemed appropriate to the review.

- Performs other duties as directed by the Historic District Commission. 


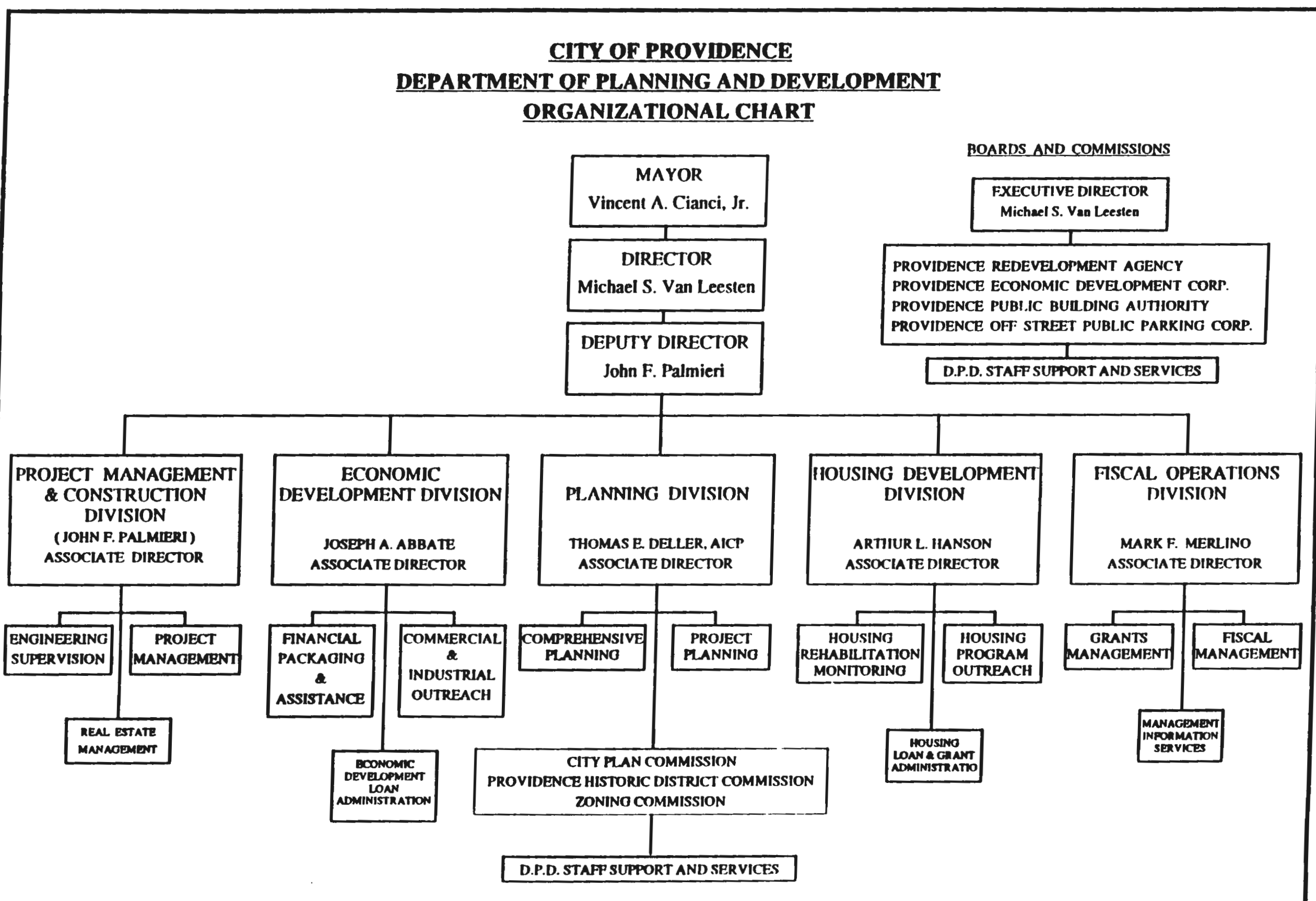




\subsection{SCOPE AND POWERS OI THE COMMISSION}

The Providence Historic District Commission oversees all matters affecting the construction, alteration, repair, moving and demolition of properties within the local historic districts. The powers of the Commission as spelled out in the City of Providence's zoning ordinance, section $501.3(1991: 43-44)$ are as follow:

Requlate Development in Historic Districts: The HDC shall be authorized to regulate the construction, demolition, change in any exterior structure and/or appurtenance within any Historic District identified on the Providence Overlay Zoning District Maps of the Official zoning Map adopted in accordance with this ordinance and identified by Section 102 .

Adoption of Rules: The HDC shall adopt and publish all rules and regulations necessary to carry out its functions under the provisions of this chapter.

Adoption of Standards and Guidelines:-The HDC shall adopt and publish standards and guidelines as necessary to inform historic district

residents, property owners, and the general public of those criteria by which the HDC shall determine whether to issue a Certificate of Appropriateness. The standards and guidelines adopted for any district located in a Downtown zone shall take into account the commercial nature of the area, and the intent established in this ordinance. The HDC may adopt different standards and guidelines for any other district. The standards and guidelines shall insure that consideration is given to the historic and architectural significance of the district, the structure and its appurtenances; the way in which the structure and its appurtenances contribute to the historical and architectural significance of the district; 
and the appropriateness of the general design, and arrangement, for both new and existing structures and appurtenances. The HDC may incorporate by reference in its rules and regulations such other standards as are appropriate, including, but not limited to the Standards and Guidelines for Rehabilitation adopted by the United States secretary of the Interior. The HDC may from time to time amend its standards as reasonably necessary, and it shall publish all such amendments.

Issue Certificates of Appropriateness: The HDC shall be authorized to issue Certificates of appropriateness for projects that conform to the requirements of this ordinance and the Standards and Guidelines adopted by the HDC. A Certificate of Appropriateness may be issued by the HDC indicating approval of plans for alteration, construction, repair, removal or demolition of a structure or appurtenances of a structure within a historic district.

Provide Advice to Other Agencies: In order to assist the City on matters of historic preservation, the HDC may provide its expertise and advice to agencies of city government as appropriate.

Delegation of Authority: The HDC may delegate to the staff the authority to issue a Certificate of Appropriateness in certain circumstances as defined in accordance with the Standards and Guidelines as adopted or by action of the HDC at a public hearing. The staff may not deny a Certificate of Appropriateness, but shall refer such action to the HDC for a hearing.

Inspection of Work in Progress: The HDC may inspect work in progress after a Certificate of Appropriateness has been issued to insure that work is proceeding in accordance with the approval received. If the HDC finds that the work in progress does not conform with the Certificate of Appropriateness, the HDC shall advise the Director of the Department of Inspection and Standards, who shall enforce the requirements of the Certificate of Appropriateness in accordance with Article VIII of this ordinance. 


\subsection{COMMISSION OPERATING ROLES AND PROCEDURES}

\section{Meetings}

The Commission schedules regular monthly meetings which are open to the public to discuss applications for Certificate of Appropriateness and other matters affecting the local historic districts. The schedule of regular monthly meetings for the calendar year is posted at the City Clerk's Office and the Department of Planning and Development. The meetings are held at the Department of Planning and Development unless otherwise specified. Applicants for Certificate of Appropriateness, abutting property owners and other interested parties receive seven day advance notification of these meetings through the mail (Providence Historic District Commission 1991b:3).

$\underline{\text { Records }}$

Written records are kept by staff of all Commission meetings, hearings, deliberations and decisions. Additionally, meetings are recorded by either an audio tape or stenographer. These records are open to the public upon receipt of written request within ten calendar days (Providence Historic District Commission 1991b:2). 
Procedures

The Commission has specific procedures which it

follows for the acceptance and review of Applications for

Certificates of Appropriateness (Providence Historic

District Commission 1991b: 4-5)

Review and Acceptance of Applications for Certificate of Appropriateness

1. Acceptance of applications - Applications for Certificate of Appropriateness are accepted according to the following categories:

- New construction/additions;

- Alterations/minor modifications;

- Signage;

- Awnings/shutters/etc.

- Site Improvements

- In-kind replacement/repairs;

- Demolition;

- Moving of historic structures.

2. Filing of applications - Applications for Certificate of appropriateness must be filed ten calendar days prior to a HDC scheduled hearing. Applications must be signed by the property owner and applicant. Additionally, they must be accompanied by all supporting documentation, including but not limited to photographs, drawings, plans, or other information as requested by the HDC.

3. Review of Applications for Certificate of Appropriateness - The HDC utilizes the criteria established by R.I.G.L. 45-24.1 and Article V, Section 501 of the Providence zoning Ordinance (Chapter 1991-29, No. 564).

4. Consideration of Applications: The applicant and his or her designated agent must appear before the Commission and testify on behalf of his or her application. Other steps which are taken include:

A preliminary statement concerning the application is given by staff, which includes a staff recommendation for approval or 
denial.

The applicant makes a presentation to the Commission explaining what the applicant intends to do to the property and why.

Statements from interested parties, including but not limited to, abutting property owners, preservation organizations, City departments and/or agencies indicating support or concern for what the applicant is proposing to do the historic property.

Once all presentations have been made the HDC members' pose questions to the applicant, the staff and other interested parties concerning their presentations and the proposed changes to the historic structure.

The meeting is then closed to public comment, and the HDC begins the process of deliberation of the application for a Certificate of Appropriateness, based upon the evidence submitted, adopted standard guidelines, and the impact of the project on the features and appurtenances of the building, neighboring structures and the character of the district.

A motion to approve or deny the application and voting.

Determinations

An application for a Certificate of Appropriateness may be approved, denied, or conditionally approved with amendments. All decisions, however, are rendered in writing with explanations given for the various decisions. When an application is denied, the specific reasons for denial are indicated on a Written Resolution. 


\section{Enforcement}

Decisions of the Commission are enforced through the Director of the Department of Inspection and Standards, in accordance with Article VIII of the Providence Zoning ordinance. Penalties and other methods of enforcement are clearly documented within this ordinance.

Additional Information

Other items that pertain to the rules and operating procedures of the Commission, such as: special meetings, attendance of Commission members, opinions and conflicts of interest are covered in detail in the Rules and Operating Procedures of the Commission. A copy of this document may be obtained by contacting the Providence Department of Planning and Development. 
3.0 THE IOCAL EISTORIC DISTRICTS 


\subsection{INTRODOCTION}

The local historic districts are areas identified as having a wealth of architecturally, historically and/or culturally significant structures which greatly contribute to Providence's sense of place. The focus of this chapter is an examination of these districts. The chapter begins by defining what is a local historic district and explaining how and why they are created in the City of Providence. Then each of the City's local historic districts are identified. Profiles of each district including information such as the date established, the geographic location, historical development, a general description and a map is used to identify the districts.

\subsection{WHAT IS A LOCAL HISTORIC DISTRICT}

Local historic districts are overlay zoning districts created to preserve structures and areas identified as historically and architecturally significant within a city or municipality. Construction, alteration, repair, moving and demolition of structures within these areas are regulated by a Commission or design review board. The primary purpose of the Commission or review board are generally: 1) to ensure that structures within designated districts are protected and preserved; and 2) to ensure that the area's uniqueness and sense of place are preserved. 
In the City of Providence the Historic District Commission is the entity charged with protecting and preserving the City's local historic districts.

\subsection{CREATION OF LOCAL HISTORIC DISTRICTS}

Local historic districts are generally created through a combination of state and local enabling legislation. In order for a local historic district to be established the State must first authorize a city or town to enact historical area zoning. The city or town must then enact its own ordinance allowing for the establishment of historic district zoning. The ordinance must clearly indicate the purpose, scope and the means of historic district implementation.

The State of Rhode Island permits communities to establish historic district zoning according to R.I.G.L. 4524.1, as documented in Appendix 1. The City of Providence, in accordance with the state law, has enacted historic district zoning. Article V, Section 501 of the Providence Zoning Ordinance authorizes the City to enact historic district zoning, as shown in Appendix 2 .

Local historic districts are currently created in the City of Providence in two ways: 1) the City identifies an area as architecturally or historically significant and designates it as such, or 2) a neighborhood group, or organization petitions the City for designation of a 
specified area. The second method is the one most commonly used. Limited staff prevents the City from actively designating local historic districts.

The following steps are taken when a neighborhood group, or organization petitions the City for historic district designation:

Step One: Neighborhood group, residents and/or their designated agent approaches their City Council Representative.

Step Two: While the City Council Representative is being approached, the neighborhood group is also consulting with the Department of Planning and Development regarding the process and procedures to be followed in establishing a district.

Step Three: The neighborhood group gathers petitions of support from residents of the area to be designated.

Step Four: A draft ordinance is written by the group for the establishment of the proposed district. The Department of Planning and Development offers guidance to the neighborhood group in drafting this ordinance.

Step Five: A Map is prepared of the proposed district.

Step Six: The City Council Representative works with the group in steps three and four and introduces the ordinance to the entire City Council.

Step Seven: City Council refers ordinance to the ordinance Committee.

Step Eight: Ordinance Committee holds a public hearing, where petitions of support and other public comments may be received.

Step Nine: The Ordinance Committee recommends approval or denial of ordinance to the City Council.

Step Ten: After the Ordinance passes two City Council 
votes, and is signed by the Mayor, the proposed district is designated.

Step Eleven: Zoning ordinance is amended to include new district.

Figure 2 is a graphic representation of this process.

FGURE 2

\section{Local Historic District Designation Process}

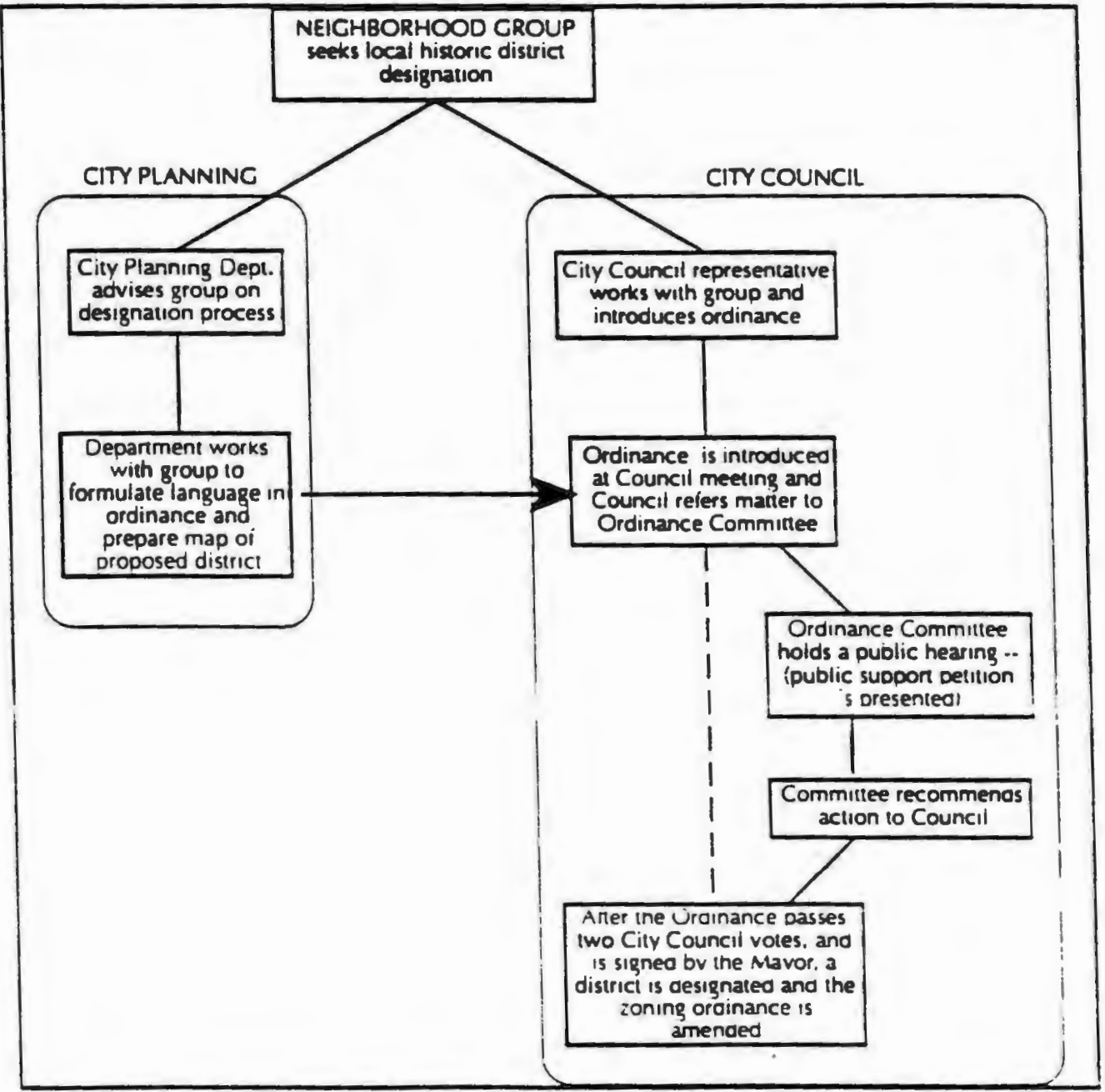




\subsection{THE LOCAI HISTORIC DISTRICTS}

The City of Providence currently has seven local historic districts. Figure 3 demonstrates six of the City's current historic districts. Profiles of the districts including information such as: the date of establishment, the geographic location, the historical development of the neighborhood in which the district is located are presented in this chapter. A physical description of each districts is also presented in the following pages. These profiles are arranged according to the date of district establishment. Each profile is followed by a district map. Other significant information pertaining to the various districts such as, the architectural styles of the properties located within the districts are contained within Appendix 3. 


\section{LEGEND}

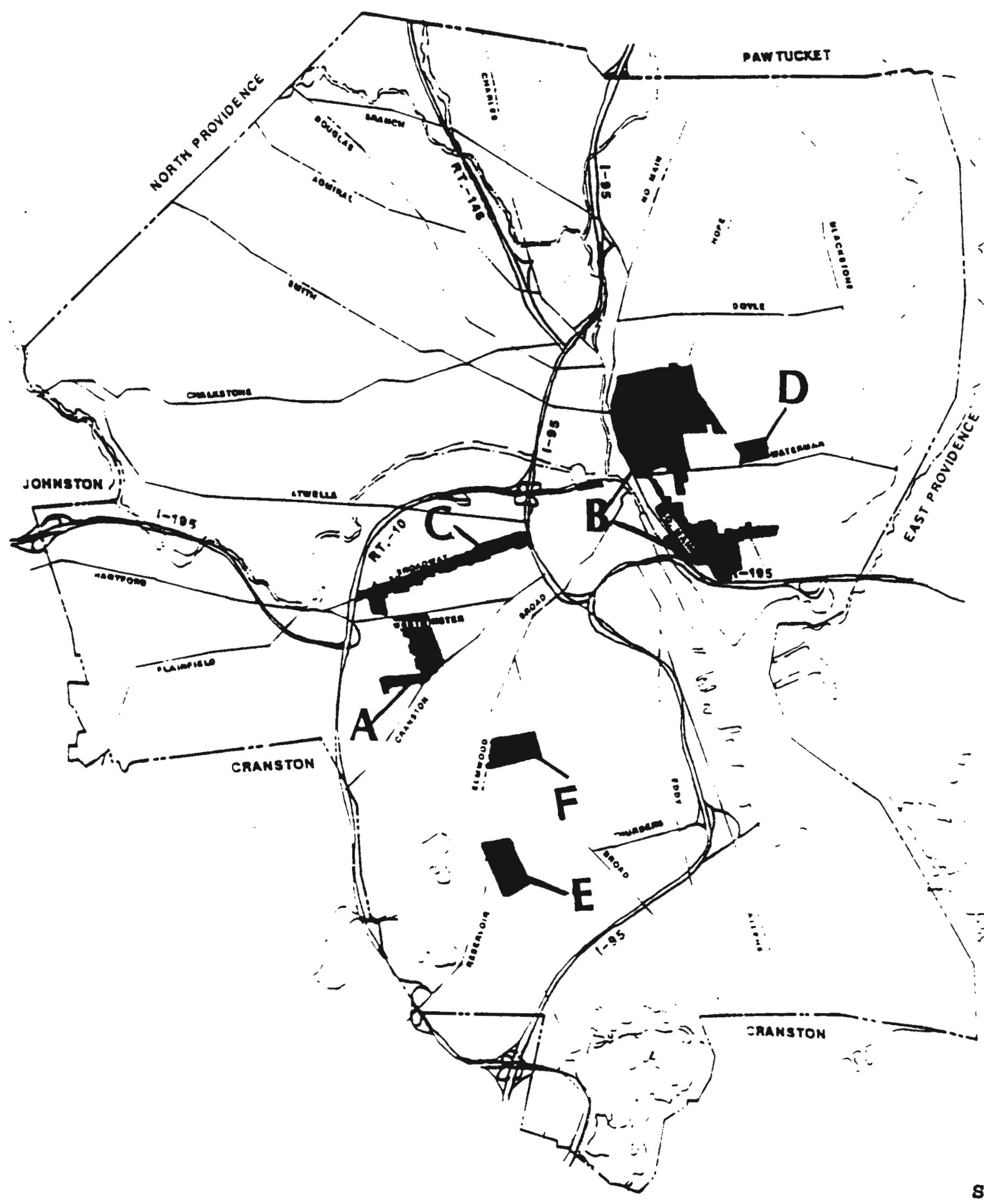

32
Source: City of Providence, Historic Department of pi zoning Kaps, Development. Provideng and Rhode Island.

\section{DISTRICTS}

A - ARMORY

B - COLLEGE HILL

C - BROADWAY

o - stimson ave.

E - SOUTH ELMWOOD

F - NORTH ELMWOOD

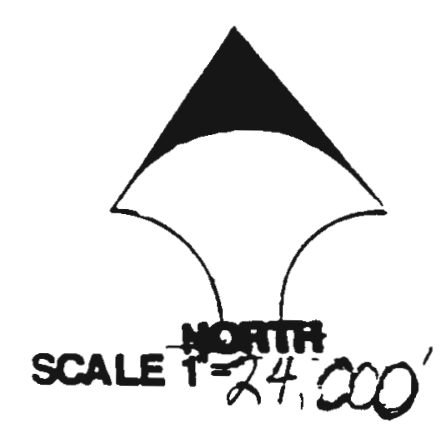




\section{TEE COLLEGE HILL EISTORIC DISTRICT}

Date Established:

Geographic Location:
1960

The College Hill Historic District is located on the City's East Side, and bounded by olney street to the north, Sheldon and Power street to the south, North Main, South Main and Benefit Street to the west and Benefit, Congdon, Prospect, Governor and Brook Streets to the east. The boundaries of this district have been amended twice since it was first established in 1960 .

Historical Development: The College Hill District is the City's first established Historic district. It is the site of Providence's original settlement in 1636. In fact, "from 1636 until the late Eighteenth Century, almost the entire settled area of Providence occupied land in College Hill along the Providence River" (Rhode Island Historical

Preservation Commission 1986:7). By the time of the American Revolution the area was densely built with wharves, warehouses, shops, public buildings, and houses mixed together. During the first half of the Nineteenth Century the College Hill area continued to grow. During and after the Civil war, the area north and east of Brown University was gradually developed (Rhode Island Historical Preservation Commission 1986:8). During the Twentieth Century, College Hill, like most areas of the City, suffered from the an outmigration of residents to the suburbs. By 1950, the area was in decay. College Hill today, however, due to the efforts of groups such as the Providence 
Redevelopment Agency and the Providence Preservation Society is an "attractive, dynamic area. The extraordinary revitalization of historic College Hill has brought national attention both for the importance of the area's history and architecture and for its historic preservation success" Rhode Island Historical

Preservation Commission 1986:9).

General Description:

This district is irregularly shaped with its boundaries varying in depth from all directions. The College Hill District contains a wide range of architectural styles including early Colonial, Georgian and Federal style buildings to name a few. Most of the buildings located within this district are in excellent to good condition. 


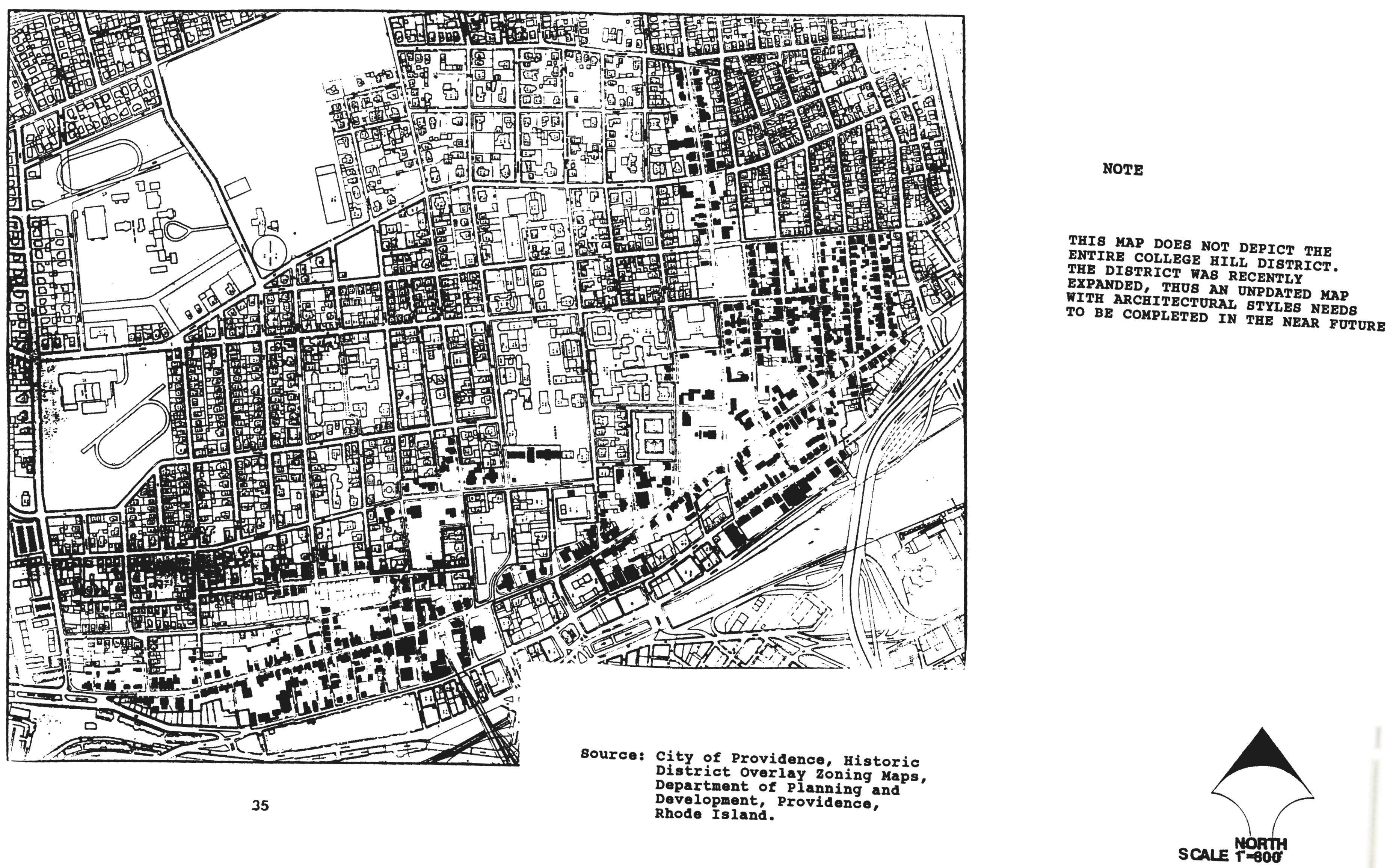


Date Established:

Geographic Location:
1981

The Stimson Avenue Historic District is located on the City's east side, near Brown University. This district consists of both sides of Stimson Avenue and of Diman Place; the north side of Angell Street from Stimson Avenue to Hope Street; the east side of Hope Street from Angell street to Stimson Avenue.

Historical Development:

The Stimson Avenue Historic District is located within the same neighborhood as the College $\mathrm{Hill}$ as thus shares the same historical pattern of development.

General Description:

The Stimson Avenue Historic

District is a small residential area comprising approximately two city blocks. The district contains 29 residential structures and a church with annexes. The Queen Anne and Colonial Revival Style of Architecture dominate the district (Rhode Island Historical Preservation Commission 1972:2). Structures located within this district are in excellent to good condition. There are no properties with major structural defects located within this district. The Stimson Avenue District is unique in the sense that most of the houses within the district have never been refaced or subdivided for offices or apartments.

Essentially, the original, quiet, tree-lined character of its streets have been maintained. 


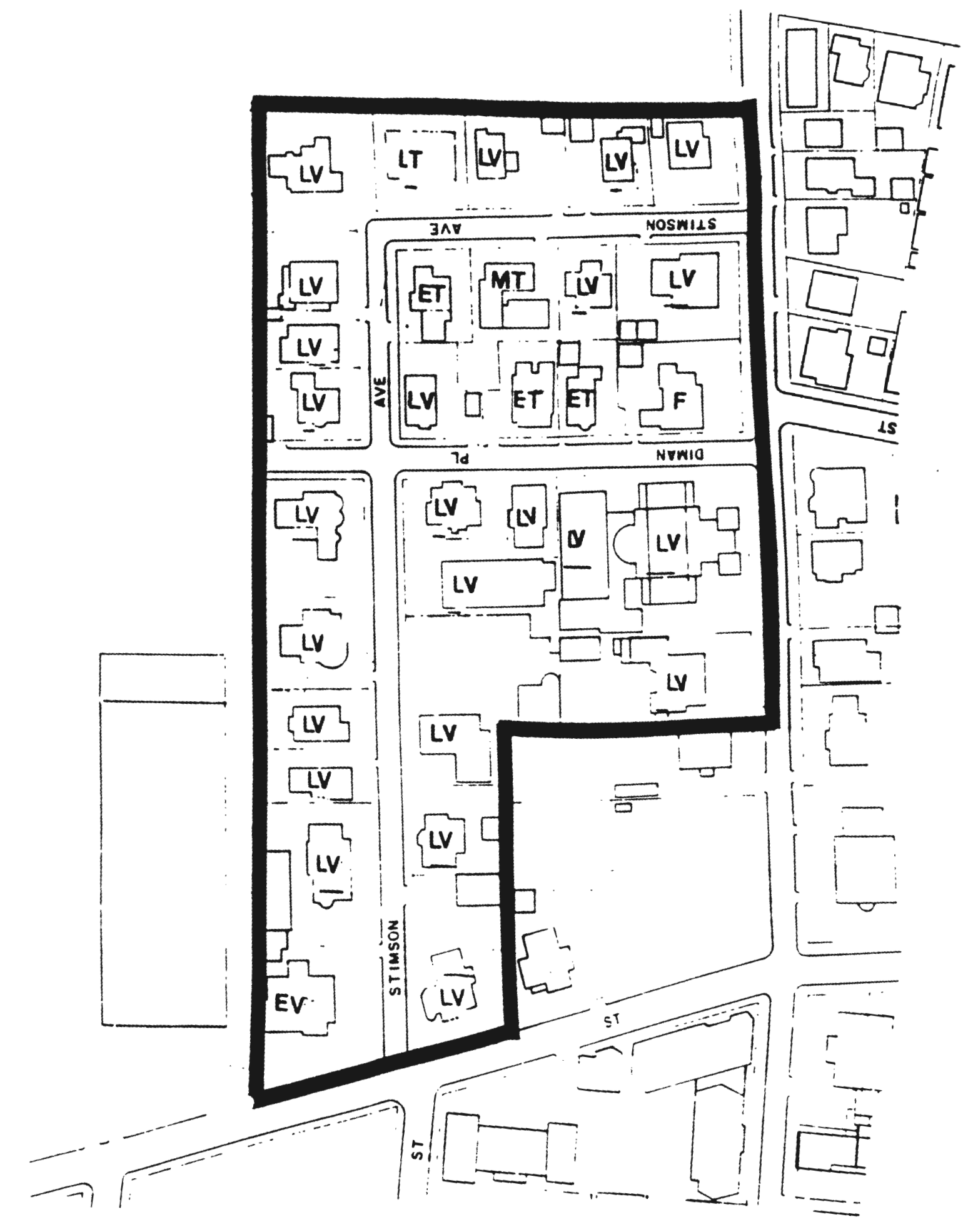

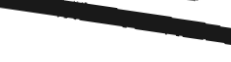
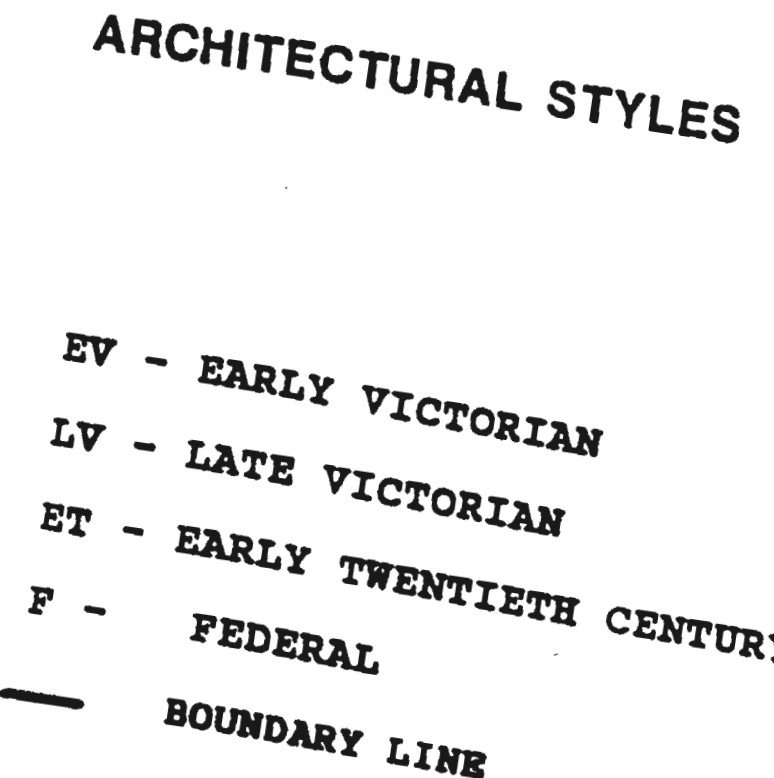
Date Established:

Geographic Location:
1982

The Broadway Historic District is located in the western section of the City in the heart of the Federal Hill neighborhood. The district extends from the north and south sides of Broadway Street, from Route 95 to Route 10. Additionally, the district is located within walking distance of Downtown Providence.

Historical Development: "Broadway Street" is the Broadway Historic District. This street was first laid out in 1834, and widened in 1854 to 80 feet. With its widening the street became "the widest street in the city, and an attraction for development by newly wealthy merchants and professional people who built grand homes. As a result the architecture which lined this street developed an exuberance unmatched elsewhere in the city" (Providence Preservation Society 1983a:1).

The Broadway Historic District is characterized by a predominance of commercial and professional land uses. It is the only district located within a residential neighborhood that is dominated by commercial land uses. The Broadway Historic District is characterized by architectural styles such as the Greek Revival, Italianate, Gothic Revival, Second Empire, Queen Anne, Colonial Revival and other Victorian styles. Most of the structures located in this district are in excellent to good condition. 


\section{ARCHITECTURAL STYLES}
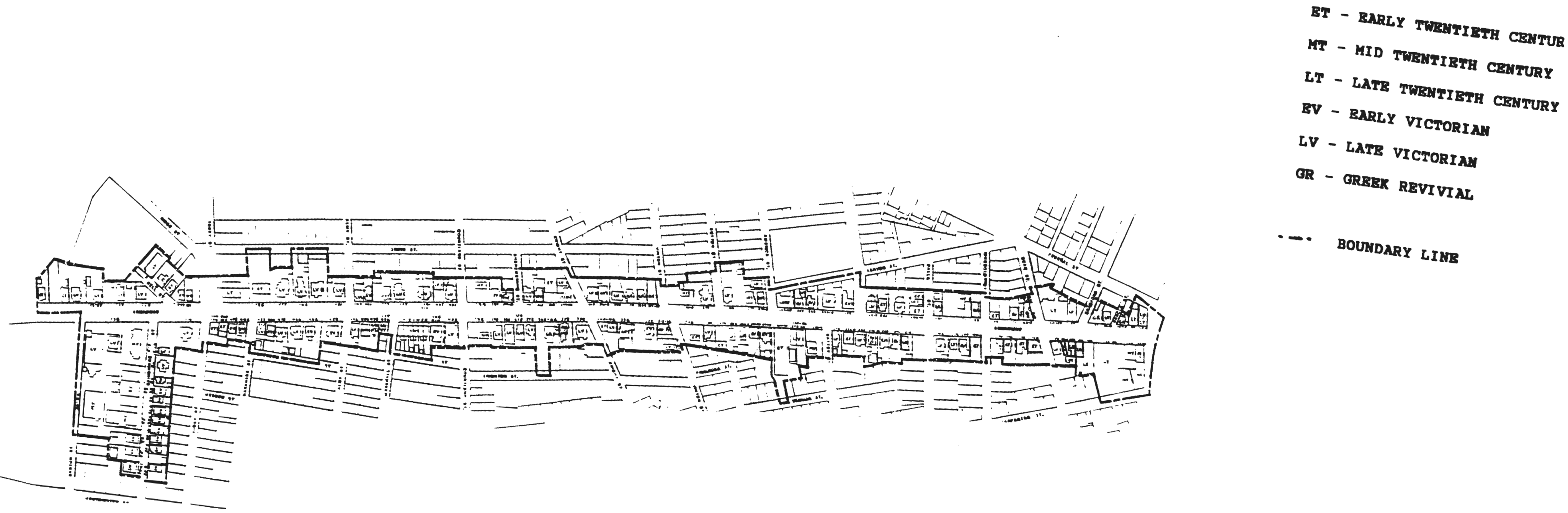


\section{THE ARMORY HISTORIC DISTRICT}

Date Established:

Geographic Location:

\section{9}

Located in the City's West End neighborhood. The Armory Historic District consists of that area immediately surrounding the old Armory and Parade Ground. It is bounded by Dexter Street to the east, Westminster and Chapin Avenue to the north, Parade Street and Messer Street to the west and Cowper and Chapin Avenue to the South.

Historical Development:

This area initially developed in the 1800's as a suburb of the City. removed from its densely developed areas. With the advent of the street car in 1865, the Armory area became an established urban residential neighborhood which was easily accessible to the Downtown. By 1930, the Armory neighborhood was a crowded, inner-city neighborhood. Many houses designed as one family homes were subdivided into two-(or more) unit structures. As a result of these changes, suburban living became an attractive feature to the residents of the Armory who could afford to move when new housing was built in the suburbs after WWII (Providence Preservation society 1982: 1-13).

The Armory area was negatively impacted by the suburban exodus after WW II, when many long term residents departed the neighborhood. Many homes were left unattended and the resulting impact was a neighborhood plagued with a deteriorating housing stock. In recent years, however, this area has been revitalized through the 
efforts of preservation agencies, such as the Providence Preservation Society, the Armory Revival Company and the Providence Preservation Society Revolving Fund. Now most of the homes in this district are in excellent to good condition. The Armory Historic District is comprised of a wide range of architectural styles, including Queen Anne, Italianate, and Greek Revival. Many of these homes were built after 1900 . 


\section{THE SOUTH ELYTOOD AISTORIC DISTRICT}

Date Established:

Geographic Location:
October 1991

Located in the southern section of the City, within the Elmwood Neighborhood, the South Elmwood Historic District is bounded by Congress Avenue to the north, Elmwood Avenue to the west and Melrose Street to the east, and Lenox Avenue to the south.

Historical Development: The pattern of development of the South Elmwood District, like the rest of the Elmwood neighborhood, initially a part of the City of Cranston, Rhode Island was largely determined by Joseph J. Cooke who established his estate "Elmwood" in the 1840's. He laid out "the patterns of the roads, planted trees and through conditional deeds stipulated the cost of houses to be built and their setback from the street. By the turn of the century, large stylish suburban dwellings rose among the earlier farmhouses and cottages (Providence Preservation Society 1983b: 1-12). In 1868 the City of Providence annexed Elmwood from Cranston. coming of the automobile had a profound impact on the Elmwood Neighborhood, as the principal arterial road Elmwood Avenue was widened to accommodate the automobile. With the widening of the street, a number of commercial activities were established along the road. Similar to other areas, within the City, the Elmwood neighborhood suffered suburban flight after WWII. Many of the larger homes in this area were then subdivided into apartment units. As a result of these changes, the neighborhood began to deteriorate and it lost most of its grandeur 
(Providence Preservation Society 1983b: 1-12).

General Description:

The South Elmwood Historic District is a neighborhood of large Nineteenth and early Twentieth Century homes. Adelaide Avenue and Melrose Street contain well designed Queen Anne and Queen Anne/Colonial Revival homes. From Congress Avenue to Adelaide Avenue, Colonial inspired dwellings surrounded by other less elaborate residences are evident. Homes in the South Elmwood Historic District range from excellent to poor condition. 


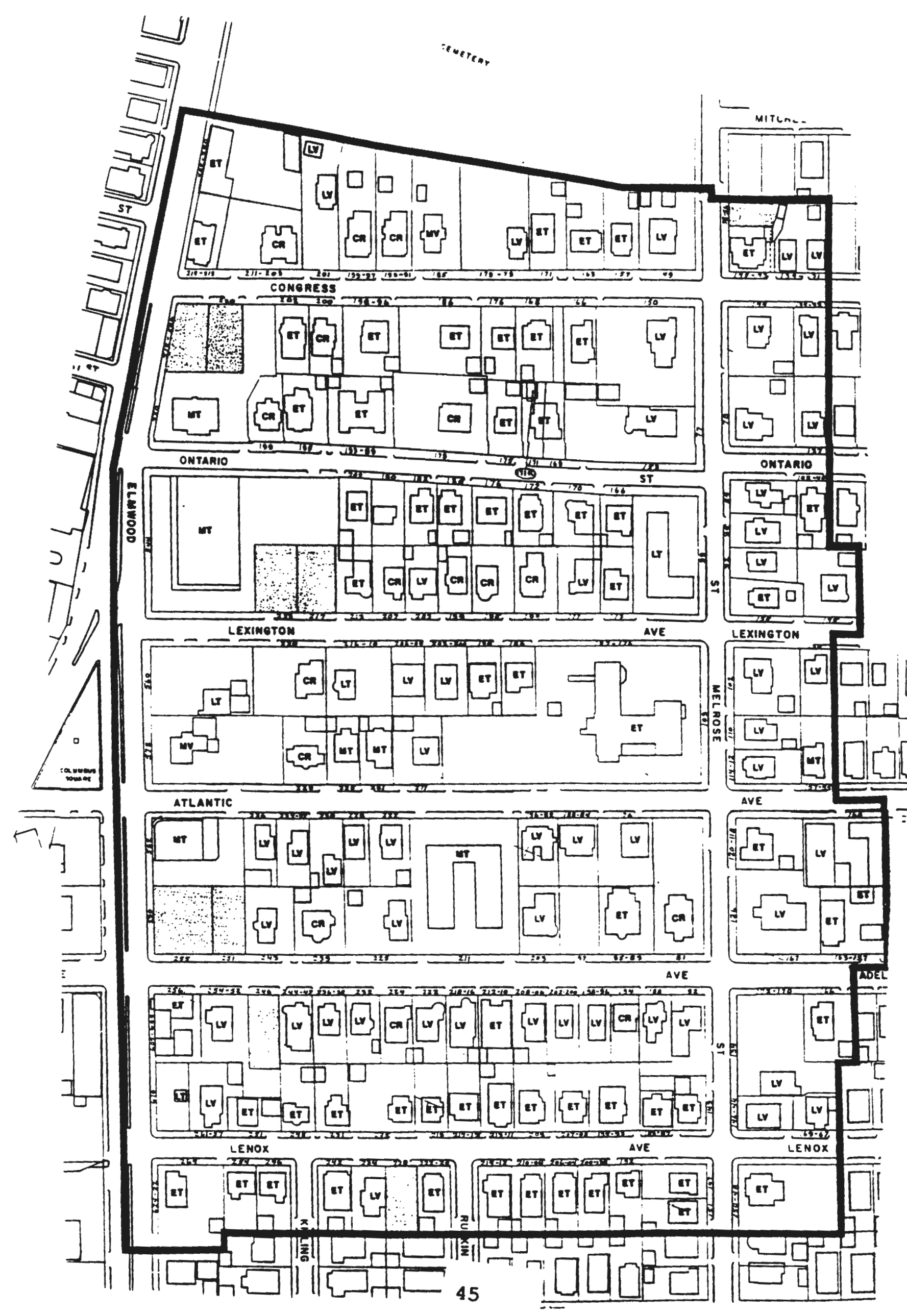

BT - BARLY TWAATIETH CHATURY

MT - Mid TWIATIRTH CantuRY

LT - LATB TWEATIBTH CEATURY

MV - MID VICTORIAN

LV - LATE VICTORIAH

CR - COLONIAL REVIVIAL

BHPTY LOT

- BOUNDARY LINE

Source: City of Providence, Historic District overlay zoning Maps, Department of Planning and Revelopment,

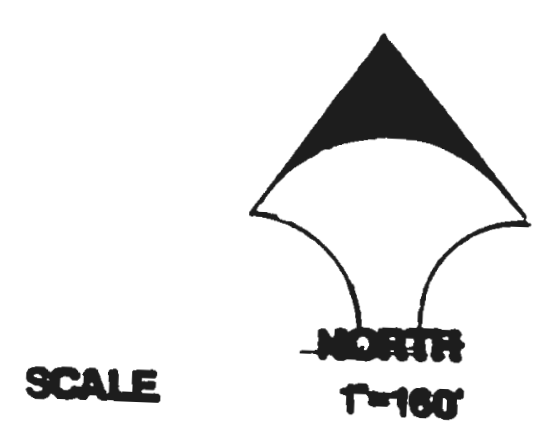




\section{TEE DOWNTOWN AISTORIC DISTRICT}

Date Established:

Geographic Location:
January 1992

The Downtown Historic District is an irregularly shaped district. All of the properties within the district are not contiguous. As a result, the location of the district is documented by three separate and distinct zones: zone 1 consists of those properties located in the Weybosett Hill, Kennedy Plaza and Financial Districts; zone 2 consists of properties located in the Retail District; and zone 3 consists of those properties located in the Jewelry District. These zones correspond to those districts established by Carr, Lynch Associates Inc. in The Providence Redevelopment Strateqy Report. Figure 9 is a map of the Downtown Districts as established by the Carr, Lynch report.

\section{Historical Development:}

Downtown Providence initially developed as an agricultural adjunct to the east side of the city. Land on the Weybosett side was gradually parcelled out to individuals in the early part of the Eighteenth century. By 1800, a thriving residential neighborhood had developed. Commercial growth had also began to occur in the $1800^{\prime} \mathrm{s}$ with the advent of the Exchange Bank. By 1820, the area around Turk's head became firmly established as the city's commercial and financial center. The mid 1850's saw the addition of a number of important buildings in the Turk's head vicinity. It was during this time period that the central business district became an area of specialized land uses. An entertainment district, a 
commercial district, industrial and residential districts were all

located within this area by the late $1850^{\prime} \mathrm{s}$. Educational institutions also began to develop in this area in this time period. The last two decades of the 19th Century gave the area its final definition. The area did not experience any more significant changes until the 1950's with the advent of urban renewal projects. The area has suffered from an outmigration of businesses and retail stores in recent years. Currently, a number of plans are being implemented to revitalize and enhance the area's attractiveness.

General Description:

This district, like the College

Hill District, is irregularly shaped. Moreover, the district is fragmented, and can conceivably be identified according to zones. All of the zones are not contiguous. Most of the properties within this district are utilized for commercial purposes. Other uses include governmental, residential, and manufacturing. "While these structures span the years between 1810 and the present and include representations of major architectural trends since the early Nineteenth Century, the greatest part of the major architectural fabric is composed of buildings erected between 1870 and 1930. These structures, despite stylistic variety of that period, share common architectural qualities such as scale, massing, and material that give the Downtown Historic District its unity and continuity. The condition of properties in this district range from excellent to poor. Sections of this district have been adversely impacted by the relocation of many businesses from the downtown to the suburbs and 
relocation of many businesses from the downtown to the suburbs and other sections of the City. A wide variety of architectural styles exist within this district. It should also be noted that this district has great potential as a economic resource and tourist attraction for the City. With a River relocation project, the building of a new convention center and a shopping area (Providence Place), the downtown is expected to draw many tourists. Currently, efforts are being made to revitalize the Downtown, particularly the old Retail Core. Additionally, there are plans to relocate I-195 in order to expand the Downtown and to join the Jewelry District to the rest of the Downtown. 


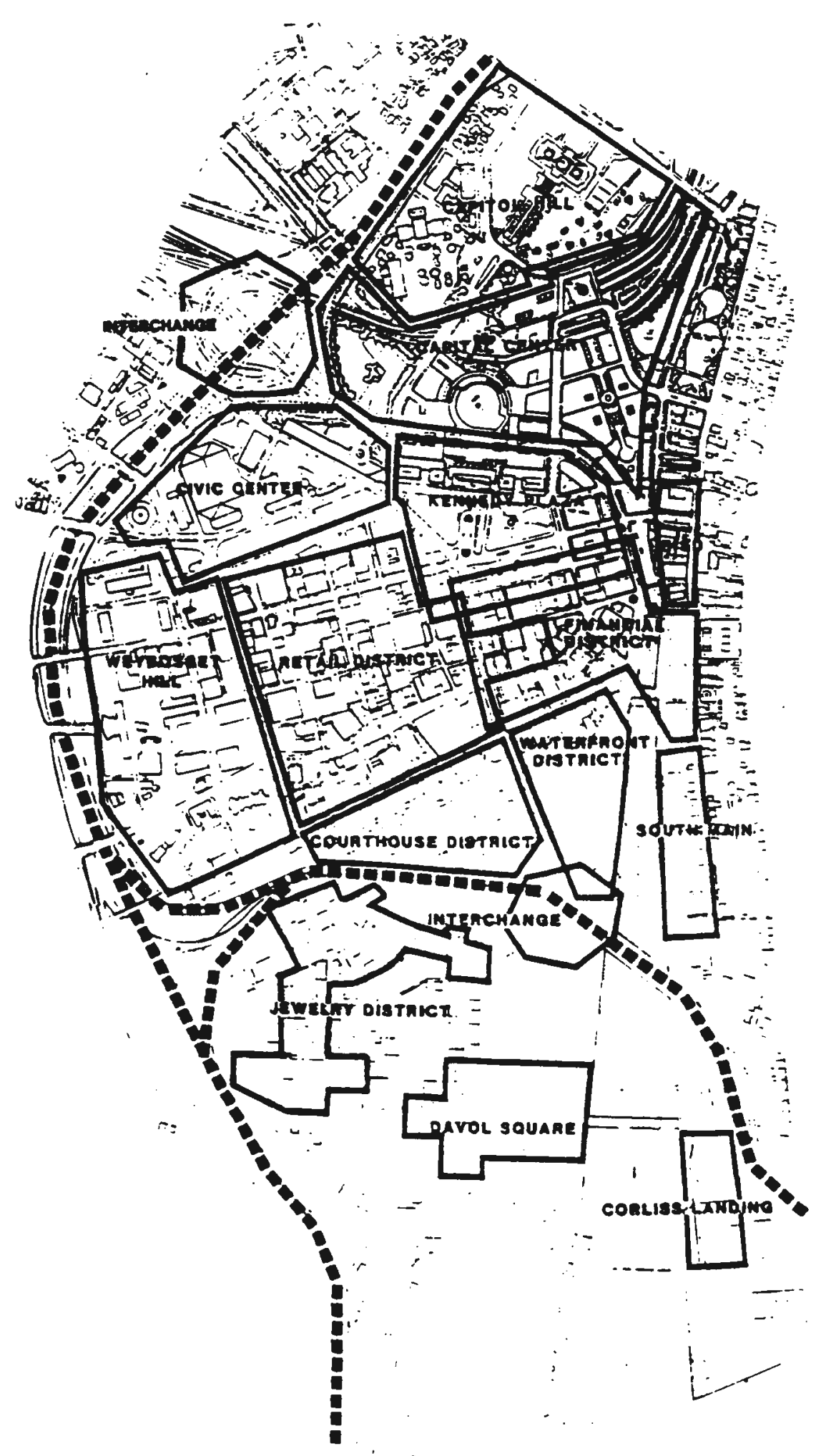

Note:

This map depicts the city of Providence Downtown Districts as established by
the Carr Lynch Report.

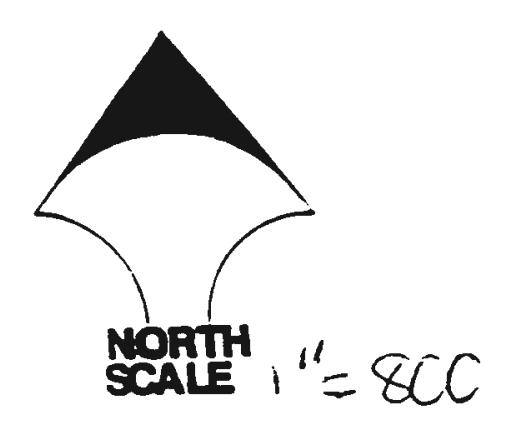




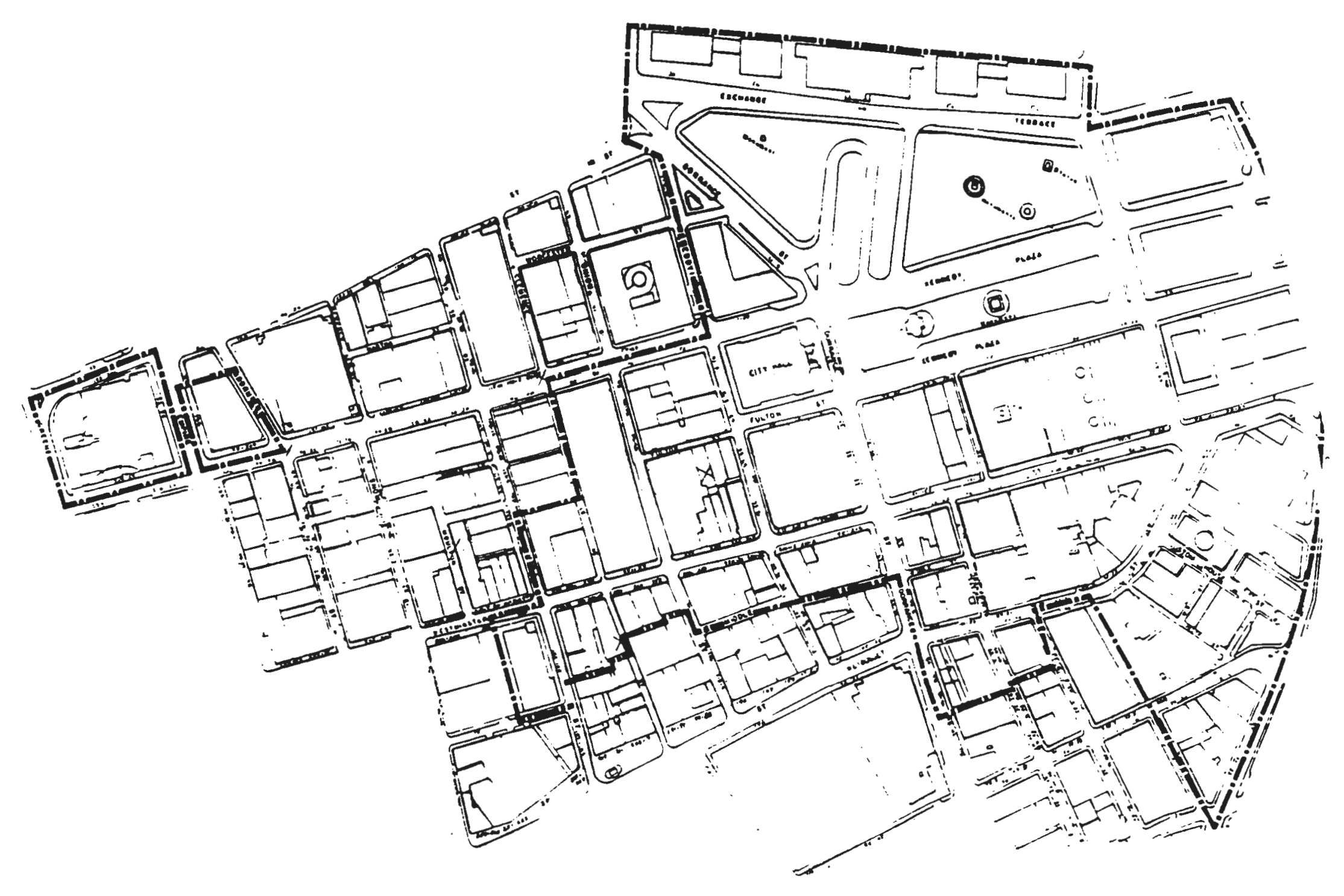

NOTE

DOWNTOWN ZONE 1: CONBISTS OF THOSE PROPERTIES LOCATED IN THE WEYBOSETT HILL DISTRICT, RENNEDY PLAZA DISTRICT,

Source: city of Providence, Historic District overlay zoning Maps, Department or Planning and Development, Providence, 


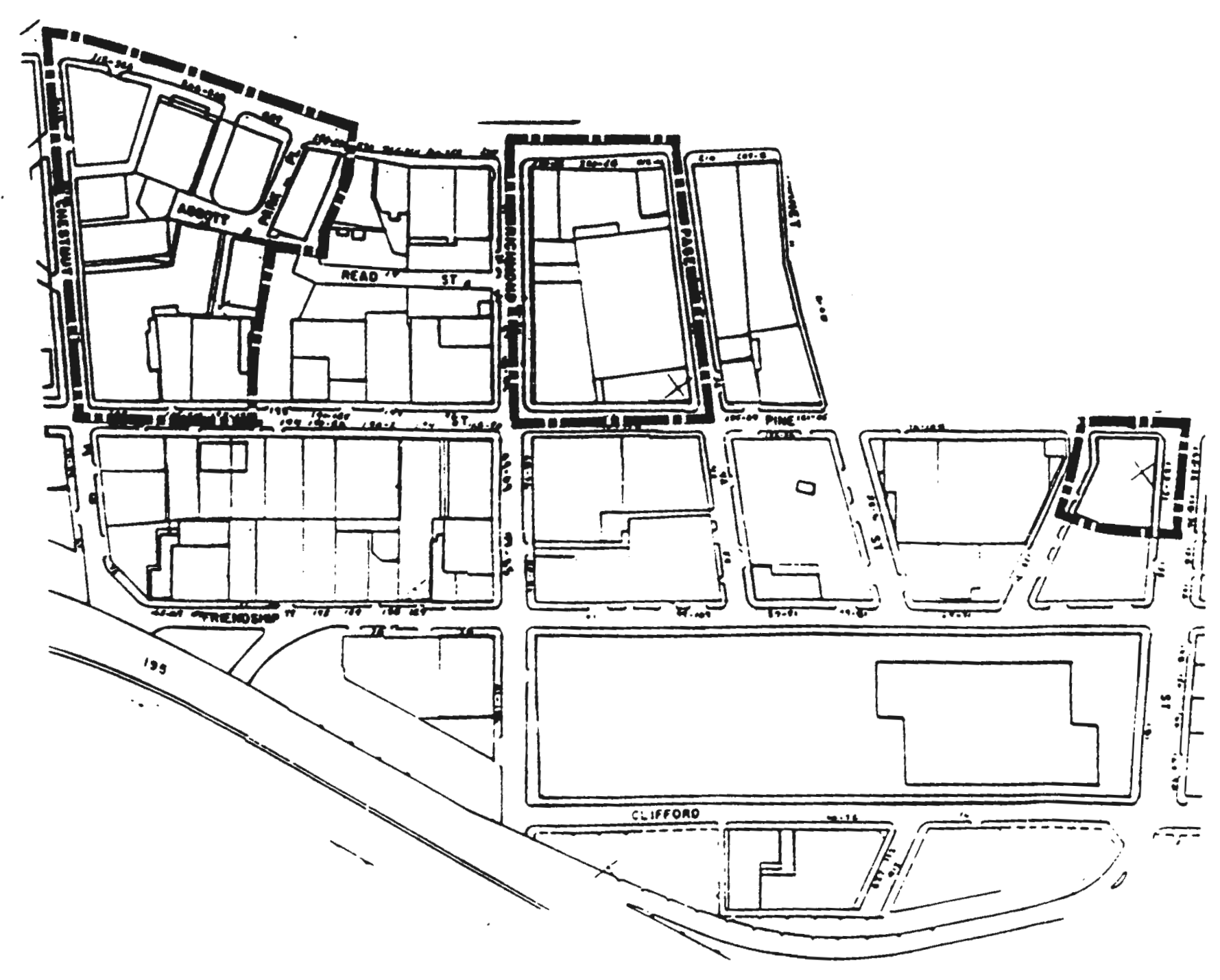

DOWNTOMN 2ONT PROPERTIES LOCATED IN THE RET THOSE
DISTRICT.

Source: City of Providence, listorte Department of lay zoning Kaps, 
THE DOWNTOW HISTORIC DISTRICT $Z O \mathcal{X E} 3$

\section{LEGEND}

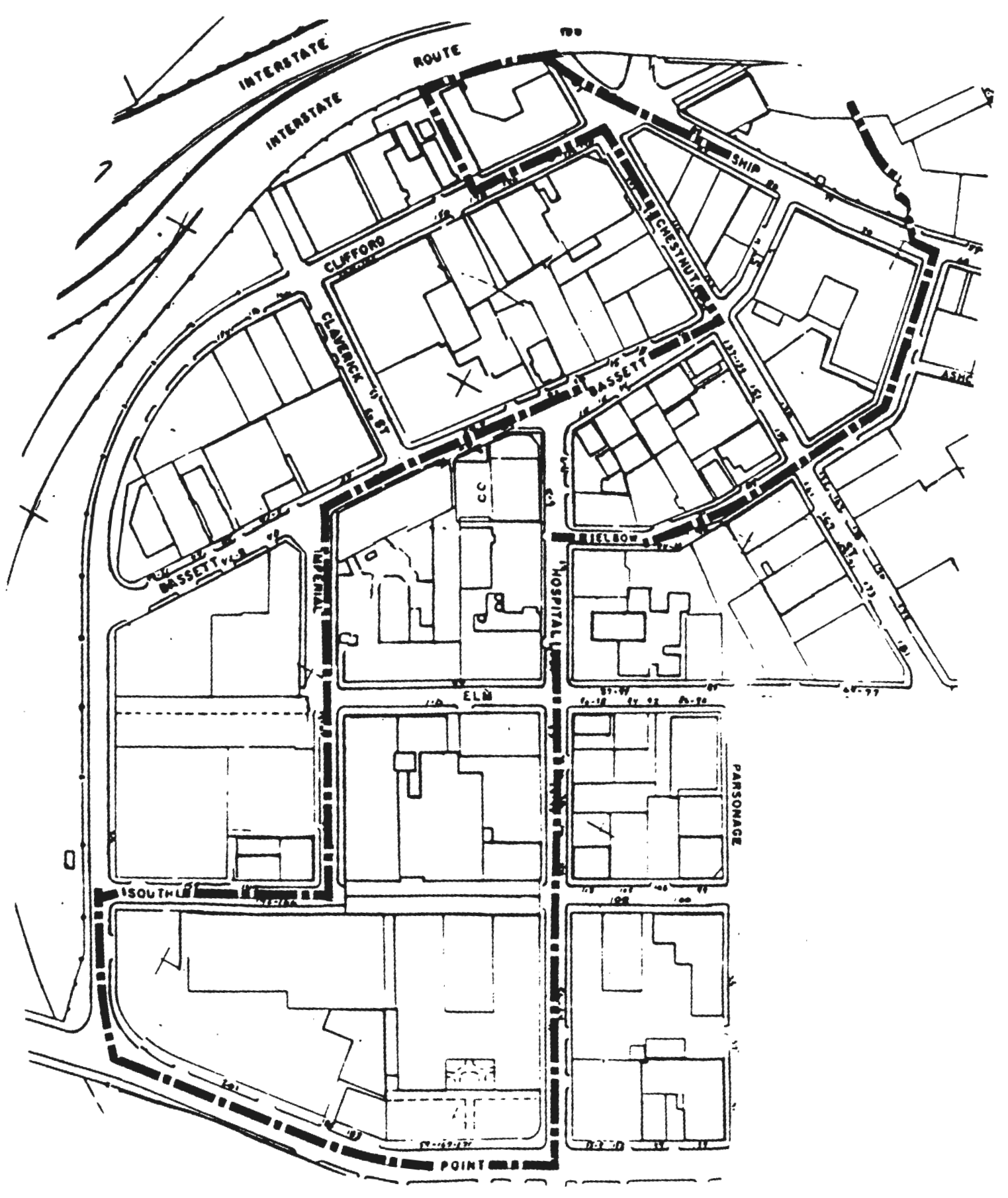

NOTE

DOWNTOMN

PROPERTIES LOC 3: CONSISTS OF THOSE DISTRICT. LOCATED IN THE JETERLY
JET 
Date Established:

Geographic Location:

Historical Development:

General Description:

\section{April 1992}

This district is located within the Elmwood neighborhood of the city of Providence. It is bounded by Whitmarsh street to the north, Moore Street to the south, Elmwood Avenue to the west and Broad Street to the east.

The pattern of development of the North Elmwood District, shares the same history of the South Elmwood Historic District as it is located within the same neighborhood.

The North Elmwood Historic District is an area characterized by narrow tree-lined streets on which are located large frame homes, built close together. Princeton Avenue and Whitmarsh Street are lined with Queen Anne, Queen Anne/Colonial Revival and Colonial Revival Structures. Also prevalent in this area are a number of three family homes built in the $1920^{\prime} \mathrm{s}$ and Commercial structures along Elmwood Avenue and Broad Street. The conditions of properties in this area range from excellent to poor. One of the major problems faced by the district is the existence of a number of institutional structures which negatively impact the residential quality of the district. 


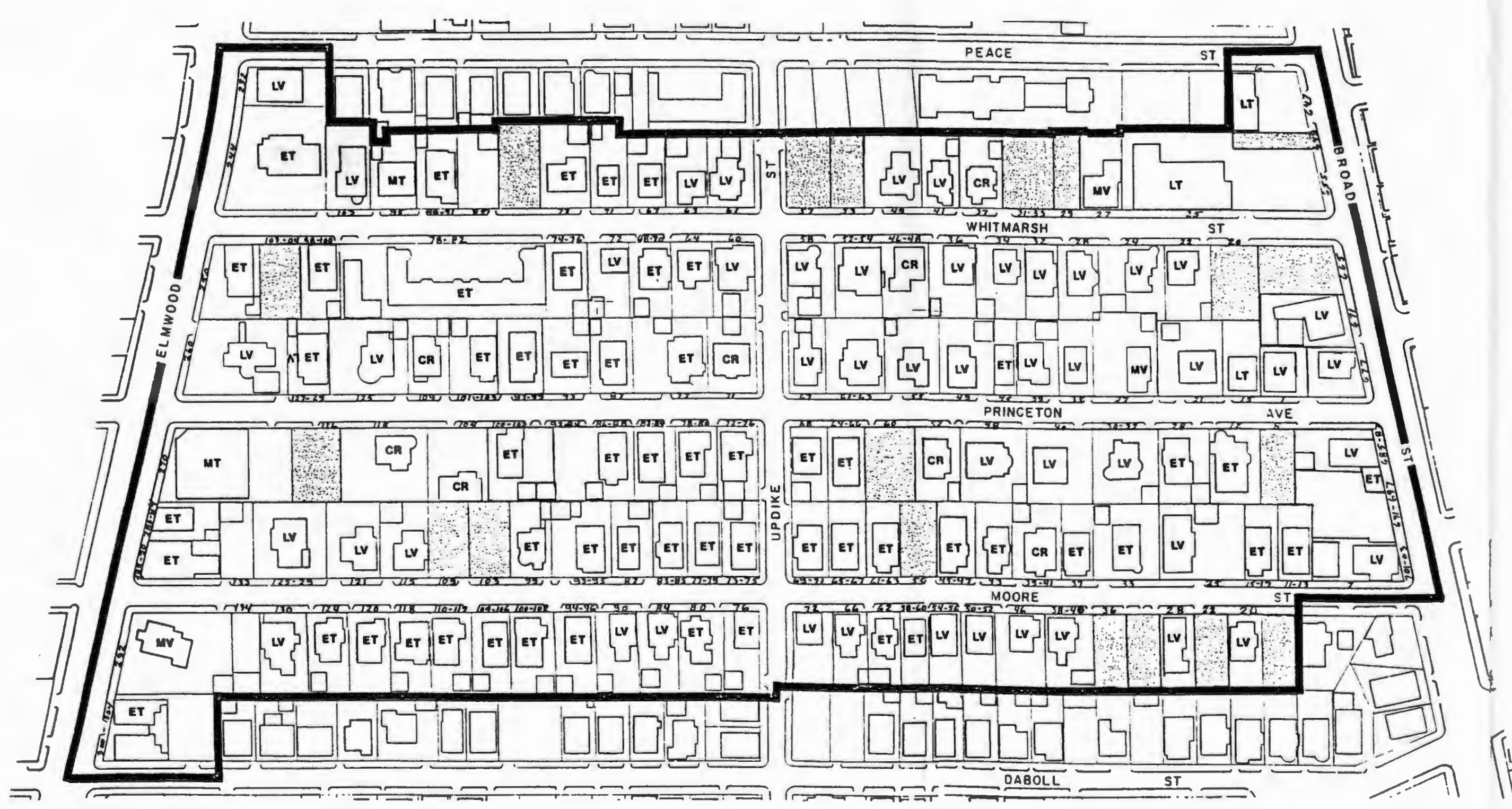

BT - BARLY TWEATIBTH CENTUE MT - MID TWENTIBTH CENTURY LT - LATE TWEHTIETH CENTUR: MV - MID VICTORIAN LV - LATE VICTORIAM CR - COLONIAL REVIVIAL

Ag. EAPTY LOT

- BOUTDARY LIME

Source: City of Providence, Historic District Overlay zoning Maps, Department of Planning and 
4.0 DESIGN REVIEW GOIDELINES TOR THE IOCAL HISTORIC DISTRICTS 


\subsection{INTRODOCTION}

Owners of historic properties should be fully aware of the guidelines/standards utilized by the Commission in its review of changes that affect the exterior appearance of local historic district properties. The chapter begins with an examination of design review guidelines and an overview of the purpose of these guidelines. The chapter progresses with a review of the various guidelines utilized by the Historic District Commission, beginning with Secretary of the Interior's Standards and Guidelines which the Commission complies with in intent. These are followed by more specific guidelines that are custom tailored to address key design issues, such as: rehabilitation of existing structures, new construction/additions, alterations/minor modifications, moving of historic structures and signage. In discussing the design issue guidelines, those changes reviewed by the Commission through the public hearing process and those items reviewed by the staff of the Commission are identified and discussed separately. Additionally, those items which are not reviewed by either the Commission or its staff, but are identified as having an impact on the overall character of a historic structure are documented. This chapter concludes with a discussion of District Specific Guidelines. 


\subsection{WHAT ARE DESIGN REVIEW GOIDELINES}

Design review guidelines are principles which guide a City's Historic District Commission or other design review board in determining actions that will not adversely impact the historic or architectural character of designated structures and their surrounding areas.

Many communities, including the city of Providence, utilize design review guidelines to maintain existing district character based on considerations of architectural history, architecture and design (Bowsher 1985:11).

Additionally, design review guidelines promote consistency and objectivity in the review process. They also provide property owners (applying for Certificates of Appropriateness) with an indication of how their applications will be judged. Good design review guidelines generally accomplish the following objectives (Bowsher $1985: 26):$

1. Identify the most important design review concerns in the district (frequently these relate to rehabilitation rather than new construction, which is more commonly associated with guidelines).

2. Provide review board members with minimum standards for making decisions.

3. Help assure that all applicants are treated uniformly and fairly.

4. Promote consistency in decisions.

5. Establish evidence of fair procedure and objective criteria that strengthens the position of the review board should its decisions be challenged in court. 
6. Clarify standards of appropriateness for applicants, architects and contractors, making it easier for them to comply.

7. Inform district property owners about rehabilitation and maintenance techniques that respect the existing architectural fabric, enhancing owners' investment.

8. Speed the processing of routine alterations.

9. Increase public awareness of the architectural character of the historic district and the elements that contribute to it.

\subsection{DESIGN REVIEN GUIDELINES FOR THE IOCAL HISTORIC DISTRICTS}

\subsubsection{General Review Guidelines}

The Commission complies in intent with the secretary of the Interior's Standards and Guidelines for Rehabilitation (Historic District Commission 1992a:1). These guidelines pertain to buildings of all occupancy, and construction, types, sizes and materials. Additionally, they apply to both permanent and temporary alteration/construction on the exterior of buildings within the local historic districts. The Commission has adapted the following general guidelines, which are based upon those set forth by the secretary of the Interior:

1. Original or historically significant materials and/or features of a structure or site shall be maintained and repaired rather than replaced whenever possible.

2. If replacement of existing materials or features is necessary, the new feature shall match the old in design, color, texture, and other visual qualities. 
3. Replacement of missing features should be based on documentary, physical, or pictorial evidence.

4. Every reasonable effort shall be made to require minimum alteration of the building, structure, site or environment.

5. Each property shall be recognized as a product of its own time. Alterations that have no historical basis and seek to create a false sense of historical development shall be discouraged.

6. Changes to a building or site which have taken place over time are evidence of its history and development. These changes that have acquired significance in their own right shall be recognized and preserved.

7. Distinctive features, finishes, and construction techniques or examples of craftsmanship that characterize a historic property shall be treated with sensitivity.

8. New additions, exterior alterations, or related new construction shall not destroy historic materials that characterize the property. The new work shall be compatible with the massing, size, scale and architectural features to protect the historic integrity of the property and the site.

9. Wherever possible, new additions or alterations to structures shall be done in such a manner that if removed in the future, the essential form and integrity of the structure and the site would be unimpaired.

4.3.2 Desian Issue Guidelines: Commission Review

The design issue guidelines as stated pertain to issues, such as new construction/additions, alterations/minor modifications, moving of historic structures and signage. Specific design review guidelines and submission requirements of the Historic District Commission as contained in The Providence Historic District Commission Standards and Guidelines for the Existing 
Historic Districts (1992a:15-25) are indicated as follows:

\section{A. NEW CONSTRUCTION/ADDITIONS}

\section{Design Objectives/Considerations}

The great variety of architectural styles found in Providence's historic districts makes it impossible to apply specific new construction guidelines. However, clear, general guidelines dealing with building height, mass, scale, siting, rhythm, materials, etc. give the architect and property owner a framework within which creativity and the needs of the current property owner can co-exist with respect for designated historic districts.

The philosophy of the PHDC since its inception in 1960 has been to promote good design, often contemporary in nature, that fits within the context of the historic districts. Additions may be designed in the spirit of the existing architectural style or may be clearly differentiated from the historic structures but compatible with the character of the historic structure and the surrounding district.

In order to provide the required information, it is strongly recommended that the applicant retain the services of a registered architect, design professional or engineer for the design and construction of any new project within a historic district. For the purposes of these guidelines, new construction refers to new buildings or structures of 
any kind or substantial additions or modifications to existing structures.

Communication with the PHDC staff early in the design process is essential. An application for a Certificate of Appropriateness for new construction requires a minimum of two hearings (conceptual review, final review) unless otherwise waived by the Commission.

\section{Design Criteria:}

The following architectural features shall be considered in relationship to the structure and the surrounding structures in the design process:

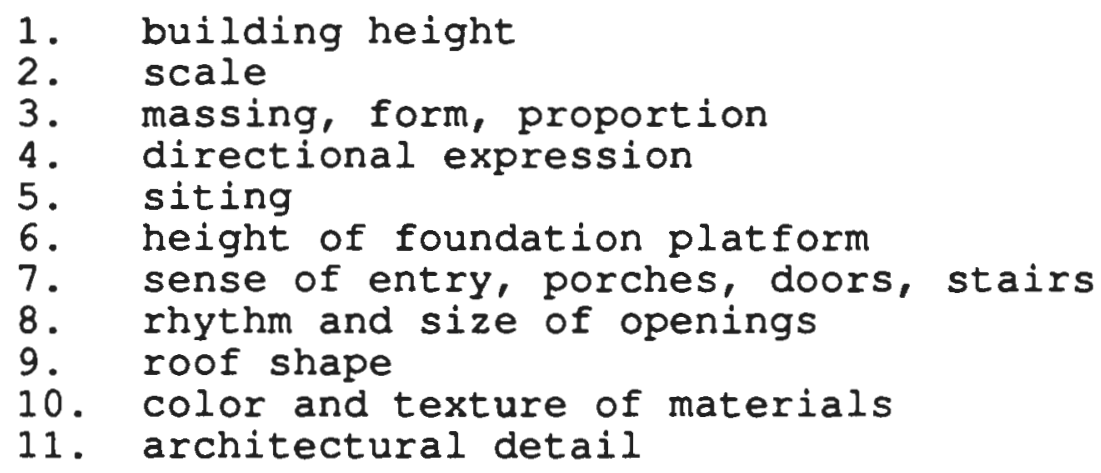

The following site features shall be considered in relationship to the structure and the surrounding structures in the design process:

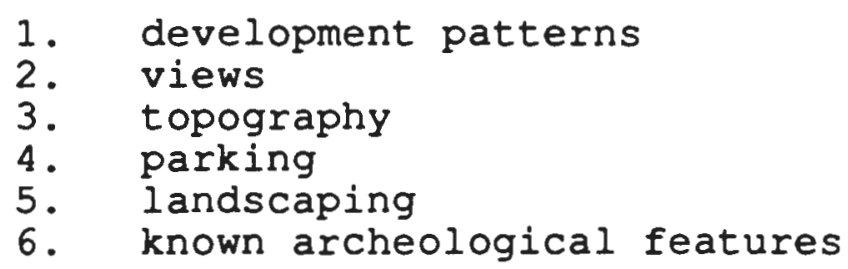


7. setbacks

\section{Information Checklist: Conceptual Roview}

The PHDC staff shall advise and assist the applicant in making formal application to the PHDC. The staff shall determine the material which is required to be submitted for review by the $\mathrm{PHDC}$. The following required information must be submitted to the PHDC staff in person by appointment at least ten (10) days before a scheduled hearing.

1. One (1) copy of a Preliminary Application signed by the property owner and the applicant.

2. One (1) set of photographs (color preferred) of a size at least 4" $\times$ 6", showing the proposed site of the new construction and all abutting properties. Photos must be labeled and dated. Instant snapshots are NOT acceptable.

3. Two (2) sets of architectural drawings of the proposed new construction. One set must be reduced to $81 / 2^{\prime \prime} \times 11^{\prime \prime}$ or $11^{\prime \prime} \times 17^{\prime \prime}$ for mailing purposes. Drawings are to be of sufficient scale to indicate clearly all aspects of the project, including but not limited to:

Site plan, including location of all new construction (drawn to scale). Site plan is to be based upon data provided by a registered land surveyor. The site plan shall clearly indicate all design features of the proposed construction including:

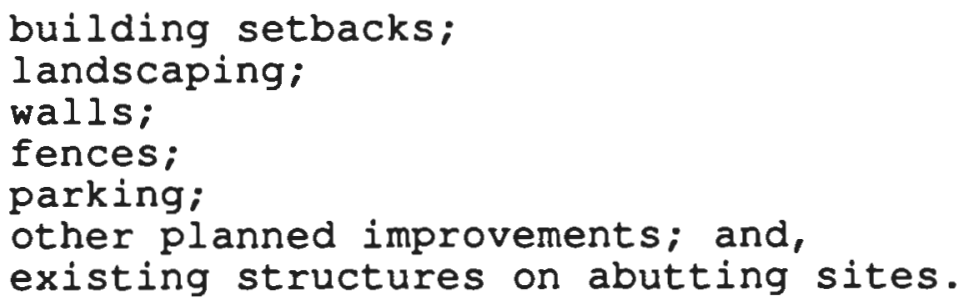

Schematic floor plans and exterior elevations of all new construction showing the full 
scope of the work proposed. Drawings are to indicate clearly the architectural quality of the proposed new construction, including:

materials;

doors and windows:

overall dimensions;

location and type of any proposed signs. exterior mounted mechanical equipment; other anticipated building or site features; and, relationship of abutting buildings (in plan and elevations).

General details of proposed new construction, as necessary to define clearly the character and quality of the proposed work, including:

architectural details and trim types; door and window types; roofing and siding; and all other features important to the visual quality of the proposed construction.

Colors of all proposed permanent exterior finish materials.

4. Three dimensional drawings and/or models to show adequately and clearly the proposed new construction in context with the surrounding area and buildings.

5. A list of the names and addresses of all abutting property owners from the most current records of the City Tax Assessor for notification purposes.

\section{Information Checklist: Final Review}

In addition to any other information requested by the PHDC and the staff at the Conceptual Review hearing or at a sub-committee meeting, the following information must be filed in person by appointment with the staff at least (10) days before a scheduled hearing: 
1. One (1) copy of a completed application form for a Certificate of Appropriateness with written

details of the proposed new construction. The application must be signed by the property owner and the applicant.

2. One (1) printed set of final architectural design drawings (full size) which depict the final design of the project in plan, exterior elevations, building sections and exterior details, as needed.

3. One (1) printed set of final architectural design drawings reduced to $81 / 2^{\prime \prime} \times 11^{\prime \prime}$ or $11^{\prime \prime} \times 17^{\prime \prime}$ for copying and mailing purposes.

\section{Procedures to Follow Once A Certificate of Appropriateness is Issued}

If the PHDC approves the design, the following steps are usually taken after the hearing:

1. The PHDC will prepare a written resolution explaining the Commission's decisions.

2. The applicant shall submit three (3) sets of architectural drawings prepared for construction to the PHDC staff for an "approved" stamp, signed by the Chair and a Certificate of Appropriateness signed by the Chair. One set is retained for the PHDC files, and two sets are returned to the applicant.

3. The applicant can then submit one set of approved drawings to the building Inspector to apply for a Building Permit.

No exterior changes may be made after plans have been approved and a Certificate of Appropriateness has been issued. Any changes not so approved shall be deemed a violation of the Certificate of Appropriateness, the State Building Code and the City zoning Ordinance.

A Certificate of Occupancy shall not be issued until 
all approvals have been met. Failure to obtain a Certificate of Occupancy can jeopardize yearly tax benefit claims and preclude final payments from banks and lending institutions.

\section{B. ALTERATIONS/MINOR MODIFICATIONS}

\section{Design Considerations}

Proposed alterations and minor modifications to buildings within the city's historic districts should be carefully considered. The preservation of these buildings is the primary purpose of the ordinance which regulates them. The Commission recognizes that the distinctive features, finishes, construction techniques or examples of craftsmanship that characterize a historic property should be preserved. Exterior alterations or related modifications should not destroy historic materials that characterize the property. New work should be compatible with the existing historic building in order to protect the historic integrity of the property and the district. In reviewing proposed plans, the Commission shall consider:

1. The historic and architectural significance of the structure and its appurtenances.

2. The way in which the structure and its appurtenances contribute to the historical and architectural significance of the district.

3. The appropriateness of the general design, arrangement, texture, materials and siting in the proposed plans.

The following information for alteration projects must be filed in person by appointment with the PHDC staff 
at least ten (10) days before a scheduled hearing.

\section{Information Checklist}

1. Application form: One (1) copy of a completed Application for a Certificate of Appropriateness with a detailed written description of the work to be performed. The form must be signed by the owner and the applicant. In the case of a condominium or a holding company, the authorized representative must sign.

2. Drawings: All floor plans, exterior elevations, and building sections must be submitted as necessary to show major architectural features and proposed changes and must be to a scale not less than $1 / 4^{\prime \prime}=1 "$. One set of drawings must be reduced to $81 / 2^{\prime \prime} \times 11^{\prime \prime}$ (or $11^{\prime \prime} \mathrm{x}$ 17 " for larger projects) for mailing purposes. One set of full sized drawings must be submitted for the hearing.

3. Photographs: Photographs must show the entire building and include neighboring buildings as well as close-ups of details affected by proposed changes. Photos must be at least $4^{\prime \prime} \times 6^{\prime \prime}$ and must be labelled and dated. Historical documentation may be included. Instant snapshots are not acceptable.

4. Plot Plan: A plot plan, to scale, showing the building on the site and the adjacent buildings.

5. A list of names and addresses of all abutting property owners from the most current records of the City Tax Assessor.

It should be noted that applications and plans must be filed in person, by appointment only. Any application deemed to be incomplete is returned. The Commission or staff may request additional information not requested above.

C. MOVING OF HISTORIC STRUCTURES

\section{Design Considerations/Objectives}

In order to preserve the historic fabric of 
Providence, the moving of contributing historic structures from their sites is an irreplaceable loss to the historic district and should be discouraged.

When a historic structure has been moved, it loses its integrity of setting and its "sense of place and time" which are important aspects of the historic building and its environment. Ordinarily, a contributing structure loses its National Register of Historic Places Status if it is moved from its contributing site.

While house moving is often viewed as a remarkable feat possible only through skillful application of modern technology, it has in fact been successfully accomplished in this country since the late $18 \mathrm{th}$ century. There are three (3) methods of moving a house:
a) intact
b) partially disassembled, and
c) completely disassembled.

often the original site and its relationship to the historic structure is as important as the building itself. Therefore, the selection of a new site, appropriate for the building, plays a key role in the success of the relocation project. It is important that the structure be moved by a professional building moving firm with experience in moving historic structures.

\section{Items to be Considered}

The owner will need to get various licenses and permits 
for the move from the Department of Inspections and

Standards and other departments such as:

1. public works

2. utility companies

3. travel of heavy equipment

4. traffic engineering

5. police and fire departments

6. proof of ability to comply with all local and state safety regulations and the ability to

7. foundation permit from the Department of Inspections and Standards

If an owner is using Federal Assistance to move a structure listed on the National Register, archeological investigations are usually required.

Historic Structures may be moved into the historic districts. In such cases, the applicant and the PHDC must take into consideration the existing architectural styles of the district and the surrounding buildings, the size of the structure in relationship to the proposed site, the existing set backs, the massing, scale, building height, texture of materials and parking.

\section{Information Checklist}

The following information must be filed in person by appointment with the PHDC staff at least ten (10) days before a scheduled hearing:

1. A completed application for a Certificate of Appropriateness signed by the applicant and the owner.

2. Complete photographic documentation of the structure and the site. Instant snapshots are NOT 
acceptable.

3. Photographic documentation of the proposed new site and the abutting properties.

4. A site plan of the proposed location of the structure indicating its relationship to the new site and the surrounding neighborhood.

5. A certified report from an engineer or the moving company describing the method of moving, expected loss of historic fabric, time table, etc.

6. A copy of the foundation permit required by the Department of Inspections and Standards including a copy of the foundation plan.

7. A list of the names and addresses of all abutting property owners from the most current records of the City Tax Assessor for notification purposes.

D. SIGNAGE

\section{Design Considerations/ Objectives}

Signs are one of the most prominent visual elements of a street. If well designed, signs add interest, color and variety to building facades and streetscapes. If not carefully designed, signs can cause visual clutter and be a major distraction from a well designed storefront or converted residential building. Although signs should be clearly visible, signage in historic districts should generally be of pedestrian scale.

\section{Issues to be Considered}

The following guidelines should be reviewed before the design review process begins:

1. The sign should be placed on the building or free 
standing in a location that will not obscure architectural details.

2. The sign should be coordinated with the placement of signage of adjacent storefronts or buildings. Placing a sign higher or lower than adjacent signs creates visual confusion.

3. A sign should identify the name, function, and perhaps the address of the business. This information can be conveyed in words, pictures, names, symbols, and logos. Too many pieces of information clutter the sign and confuse the viewer.

4. Colors should be compatible with the building and the surrounding buildings. A sign is more easily readable when the letters or graphics contrast with the background color.

5. The most traditional placement of a sign is attached flush to the building in a designated signage space. Signs can also be hung perpendicular to the wall on a decorative bracket, painted on a window, door, or freestanding. Other types of signage include awnings, neon lighting, cloth or paper banners hung in store windows or painted wall signs.

6. If lighting is to be used, it is important to consider what is to be highlighted - the sign, window display or entire building facade. Spot, track, overhanging or wall lamps are appropriate lighting sources.

Internally lit signs (backlit plastic) are incompatible with Providence's historic districts.

7. Projecting signs must have a minimum $10^{\prime}$ clearance from the sidewalk to the bottom of the sign. The size should be approximately 16 square feet. The most common shapes are rectangular, square or variations of the oval hung from decorative iron brackets.

8. Wood is the most traditional sign material but a variety of other appropriate materials are available such as metal, brass, granite, marble, slate, etc.

\section{Information checklist}

The following information must be filed in person by appointment with the PHDC staff at least ten (10) days 
before a scheduled hearing for review of signage:

1. A completed application form for a Certificate of Appropriateness signed by the applicant and the property owner.

2. Photographs of the building showing the entire area affected by the proposed signage. Photos must be at least 4" $\times 6$ " and must be labeled and dated. Instant snapshots are not acceptable.

3. A scaled drawing detailing the proposed sign on the building or in relationship to the building, such as free standing.

4. A scaled drawing detailing the sign indicating:

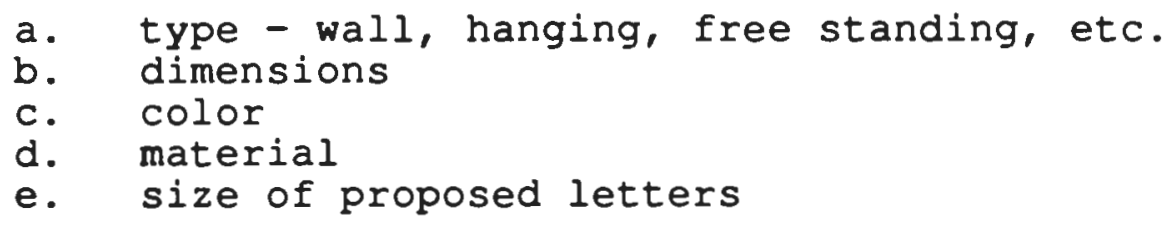

5. A set of the scaled drawings must be reduced to 8 $1 / 2 " \times 11 "$ or $11^{\prime} \times 17 "$ for mailing purposes.

6. A list of names and addresses of all abutting property owners from the most current records of the City Tax Assessor.

All signs must also comply with Article VI, Section 600-610 of the Providence Zoning ordinance. Signs which project over City property must be hung by a sign company that is bonded and insured with the City of Providence as required by the R.I. State Building Code, Section 2906, 23-27.3.

\subsubsection{Design Issue Guidelines: Staff Review \\ There are a number changes to the exterior of a structure and/or its appurtenances that do not require a}


Commission Public Hearing for the issuance of a Certificate of Appropriateness. Instead, the staff of the Commission may review these items in-house. The staff may not deny an application. Therefore, in certain circumstances, the staff may determine that an application for in-house approval must go before the Commission for a full hearing (HDC 1992a:5). Those items that may be reviewed by staff in-house generally include the following:
A. Awnings
B. Shutters and Blinds
C. Site Improvements/Driveways/Walkways
D. Storm windows and Doors
E. In-Kind Replacement/Repairs
F. Fences/Gates
G. Chillers/Condensing Units
H. Roofs/Gutters/ Downspouts

Each of these items are discussed in detail in the following pages:

\section{A. Awnings}

\section{Design Considerations/Objectives}

The use of awnings on storefronts and residential

buildings can add color and architectural interest. Awnings can help shelter passersby, reduce glare, conserve energy and serve as signage on storefronts. The material should be soft canvas, acrylic or vinyl material rather than wood or metal. Awnings should be installed without damaging the building or visually impairing distinctive architectural features. Awnings may be fixed or retractable. 


\section{Items to be Considered}

A building permit is required for an awning projecting over the sidewalk. Fixed awnings must meet zoning setback requirements. There must be a minimum $7^{\prime}$ clearance from the sidewalk to the metal frame. The awning projection must be set back at least $12^{\prime \prime}$ from the curb.

\section{Information Checklist}

1. A completed application form for a Certificate of Appropriateness signed by the applicant and the owner describing the existing conditions and the proposed changes.

2. Photographs of the building showing the entire building and a detail of the proposed awning area. Photos are to be at least $4^{\prime \prime} x 6^{\prime \prime}$ and must be labeled and dated. Instant snapshots are NOT acceptable.

3. A scaled drawing of the commercial or residential building showing:
a. front and side view of the awning
b. material and color
c. all dimensions

B. Shutters and Blinds

\section{Design Considerations/Objectives}

Exterior shutters and blinds have been used in Providence since the early 19th Century. While the original function of shutters was for light control, ventilation, and security, shutters are now primarily decorative. Solid paneled shutters were sometimes used.

Proper shutter hardware and placement is important. A 
variety of hinges, slidebolts, pintels, and shutter dogs were used and are still available. Check to see if there is evidence of hardware on the window frames or on the building. For proper appearance, each shutter should match the height and one half the width of the window opening. wood is the appropriate material. Black and dark "shutter" green were the most common colors.

\section{Information Checklist}

The following information must be filed in person by appointment with the Commission staff for IN-HOUSE REVIEW of shutters:

1. A completed application form for a Certificate of Appropriateness signed by the applicant and the owner describing the existing conditions and the proposed improvements.

2. Photographs of the building showing the proposed location of the shutters. Photos are to be at least 4" $\times$ 6" and must be labeled and dated. Instant snapshots are NOT acceptable.

3. Manufacturer's specs and product information on the proposed shutters, if available.

4. Material description.

5. Description or illustration of the size of shutters vs. size of openings.

\section{SITE IMPROVEMENTS/DRIVEWAYS/WALKWAYS}

\section{Design Considerations/Objectives}

The relationship between a historic building and its site is important in defining the overall historic character of the building and the surrounding historic district. 
Site features such as walkways, driveways, lighting, terraces and retaining walls are important in defining the history of the site and should be identified, retained and preserved. Urban landscaping may be divided into public, semi-public, and private space. The public space of the street and the sidewalk is often distinguished from the semi-public space of the front yard by a change in grade, a low hedge, wall or a fence style. These front yard appurtenances are often character-defining and should be treated sensitively.

Site improvements, such as new walkways, driveways, terraces and retaining walls should use construction materials that are compatible with the existing building, site, and historic district. Trees and shrubbery should not be placed next to building foundations which could lead to deterioration of the building fabric.

\section{Information Checklist}

The following information must be filed in person by appointment with the Commission staff for IN-HOUSE REVIEW or site improvements:

1. A completed application form for a Certificate of Appropriateness signed by the owner and the applicant describing the existing conditions and the proposed improvements.

2. Photographs of the building and its relationship to the site. Photos are to be at least 4" $\times 6 "$ and must be labeled and dated. Instant snapshots are not acceptable. 
3. A description of the proposed material for driveways, walkways, retaining walls, etc.

4. If requested by staff, a detailed site plan, not less than $1^{\prime \prime}$ equals $40^{\prime}$, showing the location of existing and proposed site improvements.

\section{STORM WINDOWS AND DOORS}

\section{Design Considerations/Objectives}

The high cost of heating fuels has made storm windows a common feature on historic buildings. While they save energy, storm windows and doors can detract from a building's appearance. Wood is a natural material that complements the texture of other materials on the building and can be painted to match the window trim. Wood should be considered whenever possible on wood window frames. Raw aluminum can also be painted to match the trim or can be purchased in several baked-on colors. Industrial, institutional and commercial buildings often used metal windows.

Interior storms, especially on the street facade, should be considered. The shape of the storm window must fit the shape of the window opening, e.g. no rectangular storms on arched windows. Windows with stained glass, leaded glass, bent glass, or unusual shapes or material may require special custom made treatment in order to preserve the window and its unique exterior visual qualities.

\section{Information Checklist}


The following information must be filed in person by appointment with the Commission staff for IN-HOUSE REVIEW of storm windows and doors:

1. A completed application form for a Certificate of Appropriateness signed by the applicant and the owner describing the existing conditions and the proposed changes.

2. Photographs of the exterior of the building and a detail of the windows and/or doors. Photos are to be at least $4^{\mathrm{N}} \mathrm{x}$ 6" $^{\prime \prime}$ and must be labeled and dated. Instant snapshots are NOT acceptable.

3. Manufacturer's specs and product information.

\section{E. IN-KIND REPLACEMENT/REPAIRS}

\section{Design Considerations/Objectives}

Deteriorated architectural features should be repaired rather than replaced whenever possible. If replacement is necessary, the new feature should match the feature being replaced in design, color, texture, material and other visual qualities. Replacement of missing features should be substantiated by documentary, physical or pictorial evidence. Current photographs serve as a record of existing conditions in all repair and replacement situations. Specific technical information is available from the Commission staff upon request for repair work in the historic districts. SANDBLASTING IS NOT ALLOWED.

\section{Information Checklist}


The following information must be filed in person by appointment with the Commission staff for IN-HOUSE REVIEW of repair and replacement:

1. A completed application form for a Certificate of Appropriateness signed by the applicant and the owner describing the existing conditions and the scope of the repair work.

2. Photographs of general views of the structure and details of replacement features as necessary. Photos are to be at least $4^{\prime \prime} \times 6^{\prime \prime}$ and must be labeled and dated. Instant snapshots are not acceptable.

3. Manufacturer's specs and product information if available.

4. Mortar mix formula's and colors for repointing. test patch may be required for masonry work.

5. Drawings, if available.

\section{F. FENCES/GATES}

\section{Design Considerations/Objectives}

Fences are an important appurtenant feature and are often an integral part of the building and its overall design. It is important that the fence design harmonize with the character of the historic structure and the surrounding district.

Street enclosures which allow visual penetration of semi-public spaces such as cast iron, wrought iron, and picket fences are characteristic of densely built urban areas. Lower fences in public and semi-private spaces should be used. Fences over 42" can obscure the view of the street traffic and create a hazard. 
The height of a fence should not exceed $5^{\prime}$ by ordinance. Fences in excess of this height require review by the City Fence Viewer in addition to approval from the PHDC.

\section{Information Checklist}

The following information must be filed in person by appointment with the PHDC staff for IN-HOUSE REVIEW of fences:

1. A completed application form signed by the applicant and the owner describing the existing conditions and the proposed improvements.

2. Photographs of the building and the site. Photos are to be at least 4" $\times 6^{\prime \prime}$ and must be labeled and dated. Instant snapshots are not acceptable.

3. An elevation showing the design of the proposed fence at $1 / 2$ " scale. The elevation should include the material, all dimensions, and manufacturer's specs if available.

4. A scaled site plan showing the location of existing and/or proposed fencing, if requested by staff.

G. CHILLERS/CONDENSING UNITS

\section{Design Considerations/Objectives}

If a chiller or condensing unit must be used as part of an air conditioning system in an historic structure, it is important that the unit(s) be placed in a location that is sensitive to the historic structure, the site and the street. Units should be as small as possible and must be screened. Refer to the Building Code for relative 
restrictions. Chillers and condensing units may not exceed the allowable decibel readings (noise levels) for residential neighborhoods according to City Ordinance.

\section{Information Checklist}

The following information must be filed in person by appointment with the PHDC staff for IN-HOUSE REVIEW of chillers and condensing units:

1. A completed application form for a Certificate of Appropriateness signed by the applicant and the owner describing the existing conditions and the proposed changes.

2. Photographs of the building and the site including abutting properties affected by the proposed location of the chiller or condensing unit. Photos are to be at least 4 " $\times$ $6 "$ and must be labeled and dated. Instant snapshots are NOT acceptable.

3. A scaled site plan and/or building plan showing the location and size of the unit and the method of screening in relationship to the property line and the building.

4. General manufacturers specs and product information.

H. ROOFS/GUTTERS/DOWNSPOUTS

\section{Design Considerations/Objectives}

The shape of the roof and its features such as cresting, dormers, cupolas, and chimneys, and the size, color and patterning of the roofing material can be extremely important in defining the overall historic character of the building. 
In addition to the design considerations, a weather tight roof with a functioning water-runoff system is essential to the preservation of the entire structure. Every effort should be made to repair and maintain original roofing materials such as slate, metal and wood.

Replacement of these textural materials with a new material can drastically affect the overall character of the structure. Roof colors should be medium to dark in tone and should complement the building's color and define the outline of the roof against the sky.

Built-in gutters should be maintained wherever possible as they are character-defining features such as Greek

Revival, Italiante, and Mansard. Aluminum gutters, downspouts, leaders, and flashing should blend in with the color of the building to reduce their visibility.

\section{Information Checklist}

The following information must be filed in person by appointment with the PHDC staff for IN-HOUSE REVIEW of roofs, gutters and downspouts.

1. A completed application form for a Certificate of Appropriateness signed by the applicant and the owner describing the existing condition and the proposed changes, including new location(s) of downspouts.

2. Photographs of the building showing the entire building. Photos are to be at least 4" $\times 6 "$ and must be labeled and dated. Instant snapshots are NOT acceptable.

3. A description of the proposed roofing, gutter, or 
downspout material including manufacturer's specs and product information.

4. The color of the proposed roofing material and/or gutters and downspouts.

\subsubsection{ITEMS EXEMPT TROM REVIEN}

A number of appurtenant features are generally not reviewed at a hearing by the Commission. Nonetheless, the visual character of these elements contributes to the overall character of a building and the surrounding historic district. The following is an attempt to guide the property owner in making appropriate and sensitive choices:

1. Liqht Fixtures: Light fixtures should be appropriate to the style of the building and not overly large or glaring. If the exposed conduit must be used, it should be painted to match the background material. Simple contemporary fixtures of appropriate size and design can be compatible to an historic district. Unornamental modern fixtures can also be appropriate. If possible, exterior flood and spot lights should not be obvious from the street and have minimal spill-over to abutting buildings.

2. Security Grilles: Metal security grilles should be simple in design and sixed to fit fully within the window opening. They should be painted a dark color, and the horizontal rails should have pierced and not overlapping welded joints. Grilles should be mounted within the reveal of the window and secured.

3. Portable Window Air Conditioners: Seasonal window air conditioners should be installed on secondary elevations within existing window openings. No through-wall air conditioners shall be allowed without a full hearing of the Commission.

4. Intercom, Alarm Devices, Door Hardware, Electrical Meters, etc: Door hardware should be compatible with the size and finish of the original examples. Buzzers, intercoms, and mailboxes should be located within the recessed entry or vestibule whenever possible. 
Louvers, registers, exhaust fans, alarm devices, cable boxes, electrical, gas, and water meters and other small mechanical and/or electrical devices should be mounted only on inconspicuous locations and painted in such a manner as to conceal them, whenever possible and permitted.

5. Window Boxes: Wooden window boxes for plants should be painted. The size should match the size of the window opening.

6. Paint Color: Paint colors are not reviewed. However, technical information on period colors and surface preparation is available upon request. Painting previously unpainted masonry surface is discouraged. Removal of paint should be done with the gentlest method possible. Disc sanding damages wood surfaces should be avoided. SANDBLASTING IS NOT ALLOWED. PRECAUTIONS SHOULD BE TAKEN WHEN REMOVING LEAD PAINT.

\subsubsection{DISTRICT SPECIFIC DESIGN REVIEW GOIDEIINES}

Recognizing that not all of the City's local historic districts are exactly the same has led to the development of supplemental district specific guidelines for certain local historic districts. These district specific guidelines address the following information pertaining to a given district: dominant characteristics, unifying elements and the subareas, different qualities and uses, and the changes taking place within the district. To date, only the Downtown District has such guidelines. A copy of these guidelines may be obtained from the Department of Planning and Development. 


\subsection{TAE PROPERTY OWNER}




\subsection{INTRODUCTION}

Owning a property in a local historic district imposes a number of obligations and responsibilities. Before noting these obligations and responsibilities, a brief mention of the advantages of historic property designation is indicated, such as: stewarding an area's rich historic, architectural and historic legacy, and belonging to an area with a sense of place and uniqueness. This chapter is devoted to explaining what historic district designation means to the property owner. The chapter consists of a series of one page summary sheets, which explain important information regarding historic district designation, the Historic District Commission and the obligations of the property owner. Summary sheets explain the following:

A. What does historic district designation mean to the property owner?

B. What is a Certificate of Appropriateness and how to apply for one?

C. The public hearing procedures and process;

D. How decisions of the Historic District Commission are conveyed to affected parties?

E. How to appeal a decision of the Historic District Commission?

\subsection{MHAT DOES HISTORIC DISTRICT DESIGNATION MEAN TO YOO: THE PROPERTY OWNER}

Owning a property in a Local Historic District obligates you to abide by a set of design review guidelines 
established by the Providence Historic District Commission. An area is designated as a local historic district because of its sense of place and identity. This sense of place and identity is established by the structures: a) unique architectural style and character (which for the most part can not be replicated); b) association with past events, individuals or associations; c) direct link with the past. A property within a local historic district is considered a community asset, and, as such, regulations are designed to protect and preserve them.

Historic district designation does not mean that one lives in a museum, or an area where change is not permitted. Instead, it means that certain changes to your property will be reviewed by the Commission to ensure that these changes do not significantly affect the character and identity of the area or result in the loss of an appealing trait or characteristic that can not be replicated. The Providence Zoning Ordinance (1991:43) authorizes the Providence Historic District Commission to regulate "the construction, demolition, change to any exterior structure and/or appurtenance within any Historic District identified on the Providence Overlay Zoning District Map". The design review guidelines of the Commission establish how and why these items will be reviewed. Copies of these guidelines are available from the Providence Department of Planning and Development. 
It should be emphasized that the Commission's scope of review is focused on exterior changes of the structure as outlined in the design review guidelines. The Commission does not regulate interior changes to the property. The following is a list of those items that are reviewed by the Commission through the public hearing process or through staff review:

Public Hearing Review Items

- New Construction/Additions

- Alterations/Minor Modifications

- Moving of Historic Structures

- Signage
Staff Review Items

- Awnings

- Shutters and Blinds

- Site Improvements/ Driveways/Walkways

- Storm Windows/Doors

- In-Kind Replacement /Repairs

\subsection{WHAT IS A CERTIFICATE OF APPROPRIATENESS AND PROCEDURES FOR APPLYING FOR ONE}

A Certificate of Appropriateness is the certificate issued to a property owner by the Historic District Commission upon approval of an owners request to make exterior changes to his/her historic property. The Commission will issue a Certificate of Appropriateness only after reviewing all pertinent information pertaining to the property owner's request.

To apply for a Certificate of Appropriateness, the applicant must do the following:

Step one: Confirm that the property is located in a local historic district by reviewing the historic district overlay zoning maps located 
at the Department of Planning and Development.

Step Two: Contact the Department of Planning and Development to arrange a site visit with staff to discuss the proposed work and to obtain an application for a Certificate of Appropriateness.

Step Three: Fill out the application for a Certificate of Appropriateness.

Step Four: Review the Historic District Commission design review guidelines to ensure that all supporting documentation is complete and properly identified.

Step Five: Submit completed application along with supporting documentation to the Historic District Commission staff, not later than ten days prior to a scheduled Commission hearing.

Step Six:

Upon receiving a completed application, staff will review application and determine if a house staff review is warranted or if the application should be reviewed by the commission at the public hearing.

Step Seven: If the staff determines that this is an application that should be heard by the Commission staff informs applicant of date and time of Commission meeting and provides a copy of the agenda. If application is to be reviewed by staff, staff informs property owner of this decision.

\subsection{THE PUBLIC HEARING PROCEDURES AND PROCESS}

The Providence Historic District Commission schedules regular monthly meetings which are open to the public to discuss applications for Certificates of Appropriateness and other matters affecting local historic districts. The schedule of regular monthly meetings for the calendar year is posted at the City Clerk's Office and the Department of Planning and Development unless otherwise specified. 
Applicants for Certificates of Appropriateness, abutting property owners and other interested parties receive a seven day advance notification of these meetings through the mail.

At the beginning of each meeting the Chairperson explains the project review process. Applicants and other interested parties that wish to testify before the Commission are told the following:

1. To state their name, business address and relationship to the project prior to beginning testimony on behalf of their project.

2. All testimony before the Commission is sworn.

3. All testimony is recorded.

Following these instructions, the review process begins and is conducted as indicated:

1. Staff report regarding the application is given which includes a recommendation and assessment of completeness of the application.

2. Applicant presents his/her testimony. The applicant may also presented written testimony if he/she so desires.

3. All interested and affected parties including expert witnesses present their testimony.

4. After hearing all testimony, the Commission questions the respective parties to ensure that all issues and concerns are addressed. This dialogue may often involve a process of negotiation.

5. Testimony is closed to the public and Commission begins deliberations.

6. The Commission votes to approve, deny or conditionally approve the application. Or the Commission may decide to rehear the application at a later date with modifications.

7. Applicants are informed that information pertaining to how to appeal a decision of the 
Commission is available from the staff of the Commission.

\subsection{HOW DECISIONS OF THE COMISSION ARE CONVEYED}

Decisions of the Historic District Commission are conveyed in writing. Additionally, the reasons and basis for decisions are indicated in writing. Section 501.6 of the City of Providence Zoning Ordinance (1991:45) explains that an Application for a Certificate of Appropriateness may be approved, denied, or approved with conditions.

If an application for a Certificate of Appropriateness is denied, the Commission must clearly articulate its reasons for rejection. Applications are generally rejected when the proposed activity is deemed to be "incongruous with those aspects of the structure, appurtenances, or the district which the HDC has determined to be historically or architecturally significant" (City of Providence 1991:45).

It is also important to note that according to the City of Providence Zoning Ordinance, Section 501.7 (1991:46) that if the Commission fails to render a decision within forty five days of the filing of a complete application, the application is deemed to be approved, unless an extension is agreed upon mutually by the applicant and the HDC.

Additionally, the Commission sends a copy of its decisions to the applicant and to the Director of the Department of Inspections and Standards, which is the agency responsible for enforcing the decisions of the Commission. 
Furthermore, no application is denied without a public hearing.

Applicants are allowed to appeal a decision of the Commission, within one year after the date of denial.

\subsection{HON TO APPEAL A DECISION OF THE COMMISSION}

Where it is alleged there is an error in any order requirement, decision or determination made by the Director, the HDC or other duly authorized agent in the enforcement of this ordinance, the Board shall hear and decide appeals (City of Providence Zoning Ordinance 1991:72).

In order to appeal a desicion of the Commission, one must contact the Providence Zoning Board of Review within 10 days of receipt of a resolution indicating denial of the application for a certificate of appropiateness. The Zoning Board of Review requires that an applicant contacts them in person for an application for appeal and to submit a $\$ 75.00$ filing fee for the application. The applicant is required to fill out two applications. Prior to the public hearing review of the application, the Board will contact the Commission staff for a record of the hearing and a copy of their decision. The Board will also notify all property owners within a 200 feet radius of the application to appeal a decision of the Commission. This notification will include a summary paragraph explaining the nature of the grievance.

There are five regular members of the Board and one 
auxiliary member. The concurring vote of three members is required to reverse or amend a decision of the Commission. No petition or appeal is heard by less than five members of the Board and no less than five members may vote including the auxiliary member.

Decisions of the Board are conveyed in writing. The reasons for the decision and the findings of fact are expressly stated (City of Providence 1991:72). All decisions of the Board are filed in the office of the Director of Inspections and Standards within forty five days and are open to public inspection. Notice of each decision is mailed to each party in interest. The Board maintains a stenographic record of all of its proceedings, including the vote of each member participating.

"Any person or persons, jointly or severally aggrieved by a decision of the Board may appeal said decision to the superior court within twenty (20) days after such decision is filed in the office of the Board". 
6.0 RESOURCES AND AGENCIES 


\subsection{INTRODOCTION}

Owners of historic properties not only have to maintain their properties in accordance with local and state building codes, but they are faced with the additional burden of maintaining an asset which has been identified as historically, architecturally and or culturally significant to the City or Town in which they live. Ideally, these property owners will have a sense of pride and ownership and a desire to maintain the unique character and identity of their property. With these concepts in mind, maintaining historic properties can be a cumbersome, complex and confusing process. There are numerous techniques and resources available to owners of historic properties, many of which property owners are not aware of. The focus of this chapter is a review of these resources and technical assistance available to these property owners. First, these resources and techniques are identified and defined. Then agencies which provide these resources are inventoried at federal, state and local levels. The chapter concludes with

a matrix that matches agencies and resources. This matrix is designed to help property owners quickly identify those agencies which can be of assistance.

\subsection{PRESERVATION RESOURCES}

There are a number of resources available to owners of 
historic properties. These resources include grants, revolving loans, tax incentives, loan programs and educational and technical assistance. Each of these resources are identified and discussed below. The definitions provided are not specific to the City of Providence or the State of Rhode Island, but rather they are general definitions.

\subsubsection{Grants}

Grants are funds provided by organizations, private corporations, cities and others to individuals for the purchase, repair and improvement of historic properties. In fact, grants are often the funding backbone for many preservation projects (Buckhurst et al. 1991:69). A grant generally does not have to be repaid. Grants can be authorized for specific types of repairs or a grant can be open ended in the sense that it may allow the property owner to do what ever types of repairs or improvements he/she desires. A grant may have certain stipulations which require the property owner to do certain things, such as live in a property for a specific period of time or not sell a property within a specified time period.

\subsubsection{Revolving Loan Eunds}

A revolving loan fund may be cash, equities, a line of credit or any combination thereof, which are owned and administered for a specific lending purpose. Principal and 
interest payments from outstanding loans replenish the fund. Thus, the fund revolves as its name implies. Additionally, a revolving fund provides low interest rate loans to property owners to fund rehabilitation and repair work.

Revolving funds are usually administered by a nonprofit organization for the express purpose of purchasing and restoring architecturally significant buildings (ziegler 1979:36). Certain restrictions are imposed, for instance the property must be eligible for, or designated on, the National Register, and rehabilitation work must be done according to the secretary of the Interior's Standards (Buckhurst et al. 1991:70). Generally, these funds are administered in certain designated areas of a city.

\subsubsection{Tax Incentives}

Tax incentives such as an income tax credit which directly reduces an individuals income tax payments are used for preservation purposes. These investment tax credits or tax credits are ususally equal to a certain percentage of total restoration or repair funds. These tax incentives may be offered at a state, local or federal level. In essence, if an owner invests in a historic property or repairs a property he/she may be able to deduct a designated amount from his/her taxes due to the federal, state or local government. 


\section{$6.2 .4 \quad$ Loan Programs}

Nonprofit organizations, state and local governments often provide loans for the purchase, repair and restoration of historic properties. Loans are often offered at interest rates below market to encourage individuals to buy and repair these properties. Additional stipulations, such as owner occupancy, time requirements and others are generally placed on these types of loans to guard against speculative investment.

\subsubsection{Educational and Technical Assistance}

Educational and technical assistance is often provided to owners and others wishing to repair/rehabilitate or maintain historic properties. Educational programs and materials may focus on topics such as:

\footnotetext{
* How to hire a contractor for restoration work

* How to research a home's architectural past

* How to restore an original feature or appurtenance

* Estimating restoration costs

* Financing restoration repairs
}

\subsection{THE PRESERVATION NETWORK}

Preservation activities take place at federal, state and local levels, thereby creating an important network of agencies and groups responsible for administering programs and other initiatives which serve to protect and rehabilitate historic properties and places of historic significance (State of Ohio 1981:96). 
Some Federal, State, City and local agencies and organizations which administer and contribute to preservation programs are identified and discussed in the following pages. The agency is identified by name and address, and when appropriate a contact person or the Executive Director is indicated. A brief explanation of what each agency does and how it may offer assistance and advice to property owners is also indicated. Some information pertaining to what some state and local organizations do to help owners of historic properties was obtained through a mail survey. A copy of this survey is featured in Appendix 5. Some information pertaining to assistance and services provided by federal agencies was obtained through a review of brochures, pamphlets and articles.

\subsubsection{Federal Agencies and Organizations}

1. The National Trust for

Historic Preservation................ (202) 673-4000

1785 Massachusetts Avenue, N.W.

Washington, D.C. 20036

The National Trust for Historic Preservation is a private, non-profit national organization chartered by Congress in 1949 to encourage public participation in preservation. The National Trust acts a clearinghouse for information and advice on preservation, assists in coordinating efforts, of preservation groups, conducts seminars and conferences, and offers internships, maintains trust historic properties and administers several grant and loan programs. 
2. Preservation Action................... (202) 659-0915 1914 Sunderland Place, N.W. Washington, D.C. 20036

Preservation Action is a lobbying organization, which works to protect and enhance the built environment. The organization seeks to get federal legislation passed and funds appropriated for preservation. It also publishes a newsletter, Alert.

3. National Center for Preservation Law.... (202) 223-8787 2101 L Street, N.W. Washington, D.C. 20037

The National Center for Preservation Law works to protect the built environment and offers legal advice on preservation and urban development issues.

Volunteer lawyers provide back-up legal assistance to community groups by phone or mail on local and state ordinances, historic districts, non-profit corporations, and tax and real estate problems. Additionally, the Center aids community groups with litigation; provides sample pleadings and briefs, and, if necessary, instigates and participates in local legal cases.

\subsubsection{State Agencies}

1. The Rhode Island Historical Society..........331-8575 110 Benevolent Street Providence, Rhode Island 02906 Albert Klyberg, Executive Director

The Rhode Island Historical Society is a valuable state educational resource. The society collects and catalogues materials and museum artifacts illustrating a history of Rhode Island. Additionally, the Society conducts public education programs and publishes original materials and analyses of documentary evidence in Rhode Island. Finally, the society operates a historical research library at 121 Hope Street, Providence, R.I. This library contains items pertaining to the history of architecture and buildings in the State of Rhode Island. Information such as architectural drawings, street directories and maps, governmental reports, published materials on architects and preservation planning is located within this library. 
2. Rhode Island Historical

Preservation Commission.................277-2678

150 Benefit Street

Providence, Rhode Island 02903

Edward F. Sanderson, Executive Director

The State Historic Preservation office is responsible for developing a state historical-preservation plan; conducting a statewide survey of historical buildings and sites and nominating eligible properties to the State and National Registers; administering programs of financial aid, including grants, loans, and tax credits; reviewing federal, state, and municipal activities to assess their effect on cultural resources; and regulating archaeological exploration on land and under state territorial waters.

Programs administered by the Commission which may be of direct assistance to property owners include: revolving loan funds, federal tax credits, easement programs, state grant funds; state income tax credits; and technical assistance.

\subsubsection{City Agencies}

1. The Providence Historic...................351-4300 District Commission 400 Westminister Street Providence, Rhode Island 02903

The Providence Historic District Commission is the agency responsible for regulating the City's local historic districts. This agency provides information to property owners pertaining to the design review guidelines established for the city's local historic districts. Property owners must contact this agency prior to making any exterior changes to a historic property.

2. The Department of Planning and Development........................... 351-4300 400 Westminister Street Providence, Rhode Island 02903

The Department of Planning and Development is responsible for a wide array of municipal services including but not limited to economic and housing 
development, project management, community development, public improvement projects, research, comprehensive planning and marketing. The Providence Historic District Commission staff is located within this office. As the agency responsible for comprehensive planning, the agency develops goals and policies for future growth and development in the City. Thus, the agency in collaboration with the Mayor's office develops goals for the preservation of the City's architecturally and significant structures. Property owners should contact this office to learn about city goals and plans for preservation. Additionally, this office houses all land use maps and zoning maps including historic district overlay maps. Thus, property owners may also contact this office to determine if their property is located within a historic district.

Specific loan programs which can be used to maintain, rehabilitate and preserve historic properties administered by the Department are contained within the City's Directory of Housing Agencies, which can be obtained from the Providence Department of Planning and Development.

3. Providence City Archives................4421-7740

25 Dorrance Street

Providence, Rhode Island 02903

The City Archives is the organization charged with securing, protecting, preserving and conserving documents relating to houses in accord with prescribed guidelines. The Archives has on file various documents of use in preservation such as blueprints, photos, property descriptions from tax record cards, maps, atlases, technical brochures and other items of interest. Property owners should contact this agency if they wish to find out about the history of their property.

6.3.4 Local Preservation Agencies

1. The Elmwood Foundation for Architectural and Historical Preservation..............273-2330 1 Trinity Square Providence, Rhode Island, 02907 
The Foundation was organized in 1975 by a number of individuals whose primary goal was to intensify the preservation/conservation efforts in the Elmwood neighborhood. Since then the organization has instituted a number of programs aimed at improving overall neighborhood conditions as well as preserving the historic fabric of the neighborhood. The Foundation assists residents by making available a contractor's list, helping prospective residents obtain mortgages, and providing advice on restoration techniques.

2. Providence Preservation Society............831-7440 21 Meeting Street Providence, Rhode Island 02903 Wendy Nicholas, Executive Director

Formed in 1956, the Society provides education, advocacy, financial and technical support for the preservation of Providence's historic buildings and neighborhoods. The society provides a wide range of services including historic house markers, advice on renovation and design review, and leadership and partnership strategies for neighborhood conservation issues. Programs which may be of particular interests to property owners conducted by the society include: 1) Preservation Resource Center - opening in 1992, a onestop spot for technical, how-to information on renovating historic buildings, including library, contractor and craftsmen referral file, materials source lists, "Old House Doctor Clinics"; 2) National Register Property Outreach Program - A program designed to help neighborhoods and property owners to maintain and improve their historic properties.

3. Providence Preservation Society

Revolving Fund Inc.....................272-2760 24 Meeting street Providence, Rhode Island 02903 Clark Schoettle, Executive Director

The Providence Preservation Society Revolving Fund Inc., is a private non-profit organization that administers a low interest loan fund for owners of historic properties in certain designated areas of the 
City for exterior building restoration. The fund also acquires properties and makes them available for purchase to people who agree to preserve them. The program has aided in the successful renovation of historic properties in the Armory, Elmwood and South Providence Neighborhoods.

\subsubsection{Other Orqanizations}

1. Elmwood Neighborhood

Housing Services.....................461-4111

9 Atlantic Avenue

Providence, Rhode Island 02907

Executive Director, Irwin Becker

The Elmwood Neighborhood Housing Services is not a preservation organization, but it has a substantial impact on preservation activities as most of its projects and programs are conducted in a neighborhood rich in historic resources. Programs and activities conducted by the group include: a revolving loan fund to assist owner/occupants in the renovation of their homes; technical assistance, specifications, supervising contractors; assisting in the purchase of homes by first-time buyers with low/moderate incomes.

2. The Providence Foundation.............521-3248

30 Exchange Terrace

Providence, Rhode Island 02903

The Foundation is a private non-profit organization which represents and acts as a spokesperson for major businesses, property owners and tax payers located in downtown Providence. Activities initiated by the Foundation include projects to enhance physical and economic development in the downtown, including the establishment of a loan pool to stimulate residential housing. Additionally, the Foundation is an affiliate of the Greater Providence Chamber of Commerce.

3. Stop Wasting Abandoned Property ...........272-0526 (SWAP)

439 Pine street

Providence, Rhode Island 02907

SWAP is a non-profit organization. Like the Elmwood 
Neighborhood Housing Services, SWAP is not a preservation organization, but has contributed significantly to preservation efforts. SWAP seeks to promote the conservation of Providence neighborhoods through the preservation, rehabilitation, and creation of affordable housing and facilitation of homeownership through self help, especially for low and moderate income people, in support of fair housing. Programs conducted by SWAP include abandoned building rehabilitation which focuses on rehabilitating abandoned buildings for sale to owner occupants; and cooperative housing program - a program for the rehabilitation of larger buildings and for cooperative homeownership. 


\subsection{MATCHING RESOURCES}

The following matrix has been prepared as a resource guide for individuals looking for assistance from the various agencies and organizations listed in this inventory. Each organization appears in this matrix in the same order in which it appears in the inventory. The types of services and resources offered by the agency are assigned a number. The numbers indicate the following:

1 The agency offers grants as a form of assistance.

2 The agency offers revolving loan funds as a form of assistance.

3 The agency offers information regarding tax incentives provided by the federal, state and/or local governments.

4 The agency offers loans or has information regarding loans available.

5 The agency offers educational information or technical advice.

6 The agency offers information that does not fit within the other five categories. Legal advice falls within this category.

\subsubsection{Matching Resources Matrix}

\begin{tabular}{|l|l|l|l|l|l|l|}
\hline AGENCY & 1 & 2 & 3 & 4 & 5 & 6 \\
\hline 1. National Trust for \\
Historic Preservation & & & & & $\mathrm{X}$ & $\mathrm{X}$ \\
2. Preservation Action & & & & & $\mathrm{X}$ & $\mathrm{X}$ \\
$\begin{array}{l}\text { 3ational Center for } \\
\text { Preservation Law }\end{array}$ & & & & & $\mathrm{X}$ & $\mathrm{X}$ \\
\hline
\end{tabular}


Matching Resources Matrix (Continued)

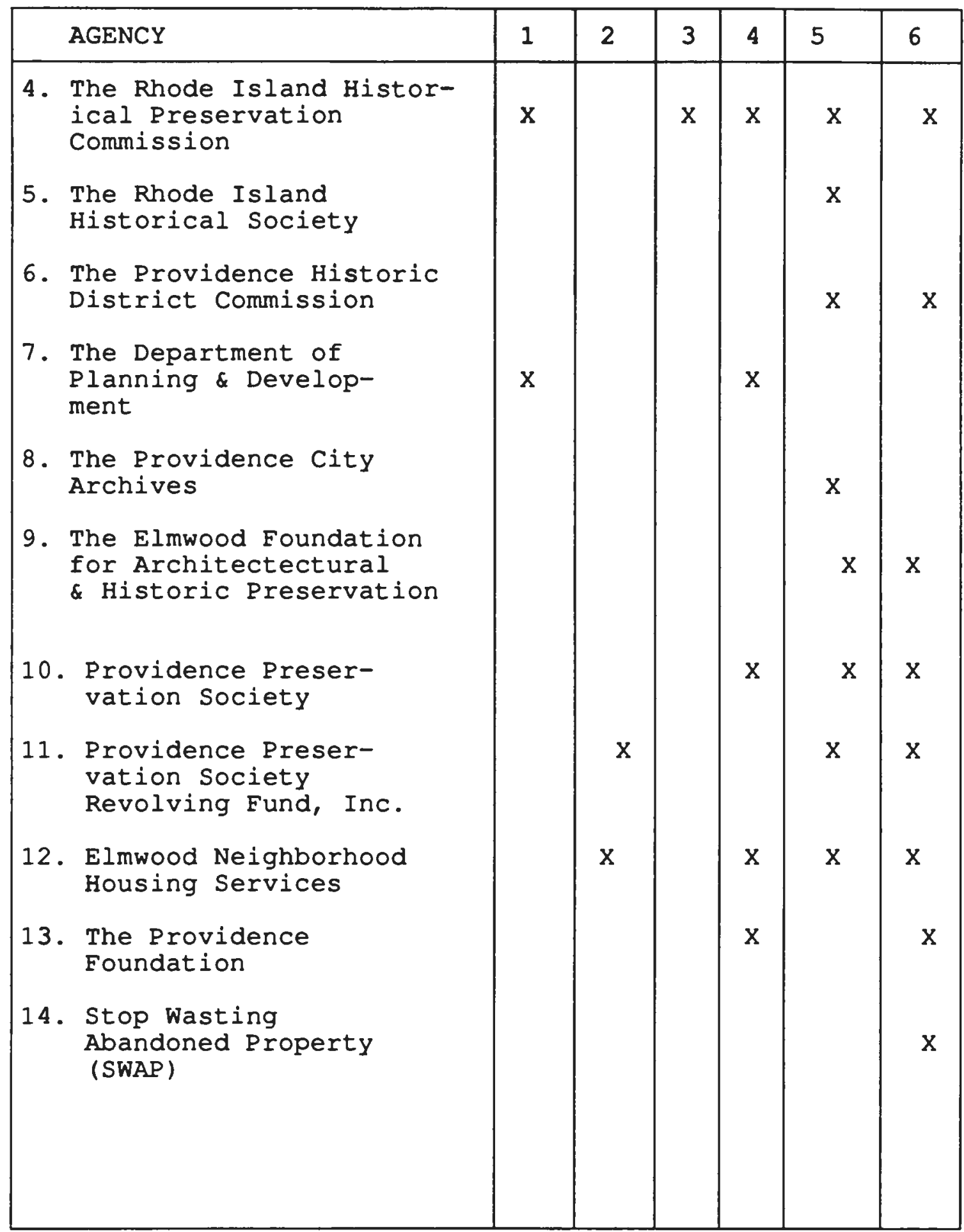


7.0 ENEANCING PRESERVATION ACTIVITIES: FINDINGS AND RECOMMENDATIONS 


\subsection{INTRODOCTION}

After reviewing a number of documents such as 1) the Commission's rules, regulations and operating procedures 2) the Commission's design review guidelines, 3) the City of Providence's Zoning Ordinance and other documents, a number of issues/needs have been identified. This chapter is devoted to addressing these issues/needs and improving and enhancing preservation activities in the City of Providence.

\subsection{OVERVIEW OF ISSUES/MEEDS}

Six issues/needs have been identified as having a significant impact upon the Commission's ability to safeguard the integrity of the local historic districts. Each of these issues/needs are discussed as follows:

Issue 1: Preservation related activities within the City of Providence are not coordinated.

In August of 1991, A Plan for Preservation was completed. This plan analyzed preservation in the City of Providence identifying weaknesses and strengths inherent in current preservation activities. The plan identified seven issues: local historic districts, institutional buildings, industrial buildings, neighborhood conservation, downtown and the waterfront. The Commission as the agency chiefly responsible for overseeing Providence's rich historic and 
cultural legacy should be an active participant in strategies to improve and enhance current strengths in preservation activities. The Commission in collaboration with other City agencies, non-profit organizations, preservation agencies and others interested parties should join together and use this plan as a starting point in forging a clear direction for the preservation of the City's rich historic resources.

Issue 2: The current historic district designation process is confusing.

Neighborhood organizations and groups wishing to have an area designated as a local historic district are not given a clear idea of how to accomplish this task. The end result is that the designation process: 1) takes a long time; 2) confuses a number of individuals who will be affected by the designation of a district and 3) allows individuals to misinform other individuals of what a local historic district is what it is not.

Issue 3: The Providence Historic District Commission does not distribute onough oducational and informational materials to district residents.

The Commission currently distributes a limited amount of educational materials. The primary documents distributed 
are 1) the Rules, Regulations and Operating Procedures and 2) the Standards and Guidelines of the Commission. Although these documents are important and contain significant information, they do not address all of the informational needs of individuals concerned with or affected by the decisions of the Commission.

Issue 4: The design reviow guidelines need to be made clearer and more comprobonsiblo.

The design review guidelines of the Commission as stated in the City of Providence's zoning ordinance (1991:43) are the primary vehicle used

to inform historic district residents, property owners, and the general public of those criteria by which the HDC shall determine whether to issue a Certificate of Appropriateness.

As a result these guidelines must be clear and consistent. The current guidelines are good, but can be improved with additional explanation of key terms and criteria.

Issue 5: The Commission should be more accessible to residents of the local historic districts.

The Commission can improve its accessibility by becoming more actively involved in the local historic districts. The commission should on occasion conduct workshops in the local historic districts, covering a wide 
range of preservation issues. Additionally, whenever possible residents of the local historic districts should be considered for Commission positions.

\subsection{IMPLEMENTATION STRATRGIES}

Implementation strategies is the final component of this study. Implementation strategies consists of recommendations and steps devised to address issues impacting the Historic District Commission's ability to effectively regulate the local historic districts. The following time frames have been established for the implementation of the recommendations contained within this study.

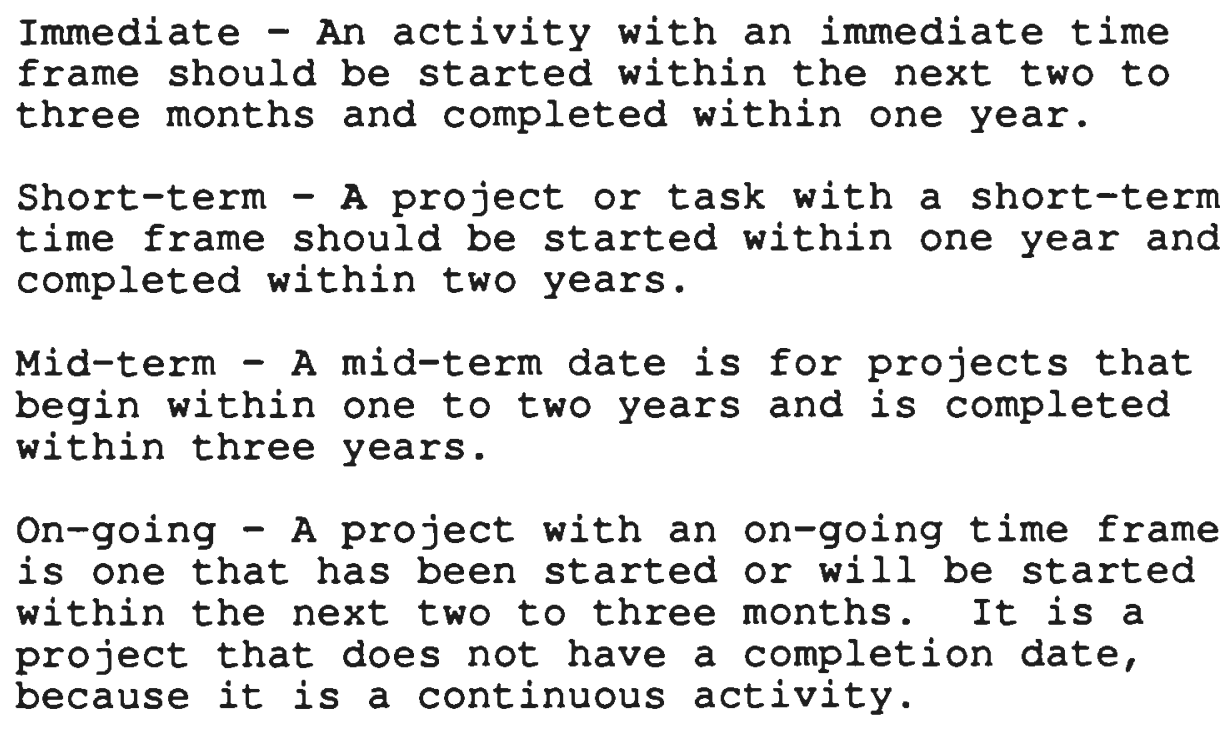

Recommendation 1: Implement A Plan for Preservation.

Figure 14 is An Action Strategy for Preservation as 
FIGURE 14

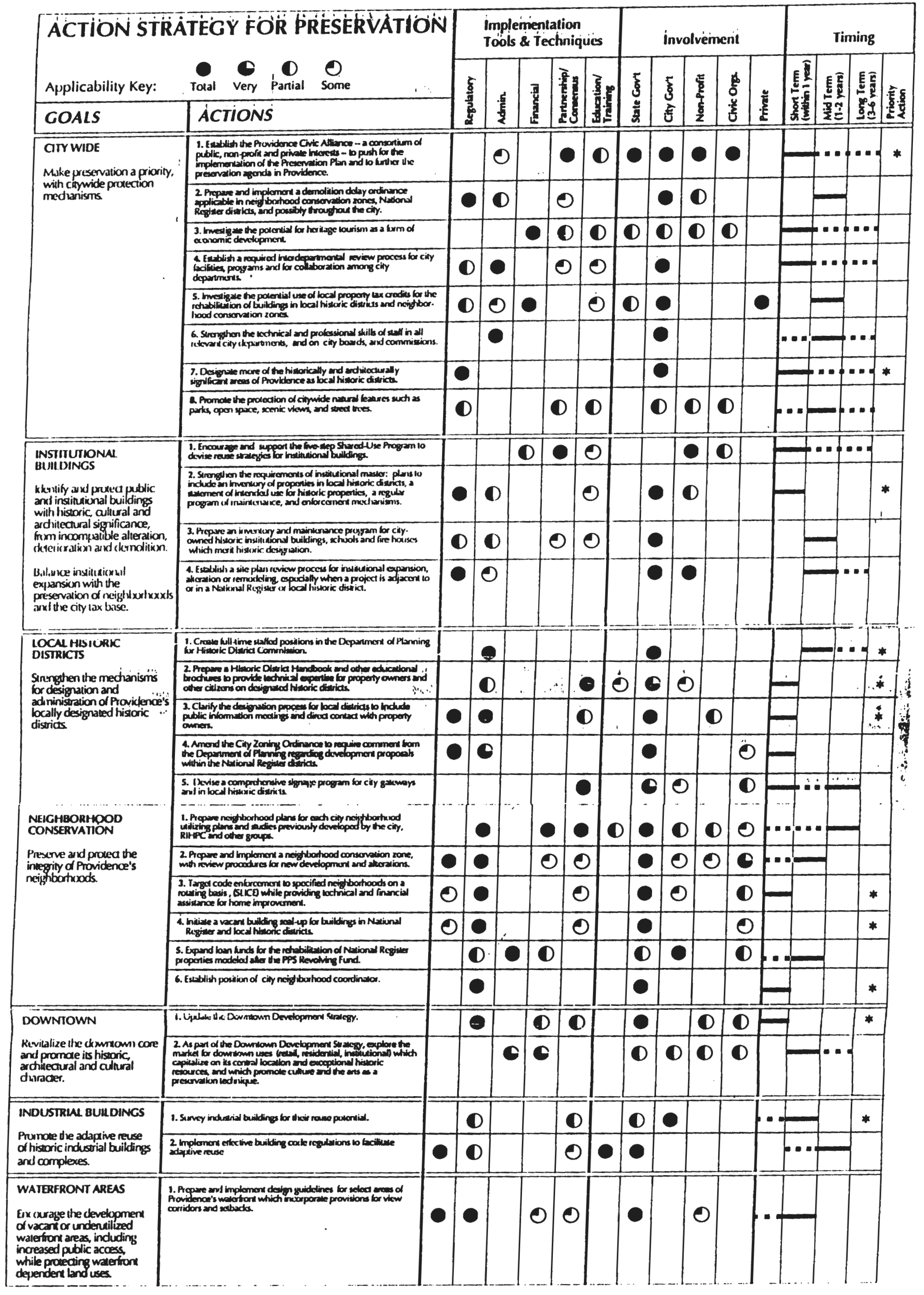

Bource: Buokhurat Fish Button rata,

A Plan for Pranervation,
August logi. 
contained in A Plan for Preservation. The Commission should work with the City, other agencies and organizations to implement this plan in order to more clearly direct the growth and development of the local historic districts.

\section{Recommendation 2: Improve and make more comprehensible the local historic district designation process.}

The historic district designation process could be clarified through the following steps:

Step 1: Clearly designate who should and can be involved in the designation process.

Step 2: Develop educational materials that explain what a local historic district is and is not and other related educational materials.

Step 3: Establish a time line for the designation process.

Step 4: Establish and publish criteria for designating an area as a local historic district.

The time frame suggested for this recommendation is immediate.

Recommendation 3: Amend the local historic district designation process to ensure clarity and consistency.

The local historic designation process should be amended to include the following steps.

Step 1: Individual, organization or community group contacts Historic District Commission Staff regarding the establishment of a local historic district. 
Step 2: Individuals must clearly identify to staff the proposed area on a map with the boundaries designated.

Step 3: Staff provides individual with educational materials, brochures, petition forms and written procedures for establishing a local historic district. Staff also informs individual that he/she must have a City Council representative to introduce the ordinance establishing the local historic district.

Step 4: Individual must return to staff within two weeks with the name of council representative, petition forms signed by residents of the proposed district and a written statement explaining why he/she wants the are designated a local historic district.

Step 5: Staff to survey proposed area and prepare a written report explaining how it meets the criteria established for local historic districts as defined by the Commission and the City.

Step 6: The staff forwards this written report, petitions and written statement to the Commission and the Department of Planning and Development within three weeks of receipt.

Step 7: Department of Planning and Development furnishes a written opinion with respect to the relationship of the designation to the Comprehensive Plan within thirty days of receipt of all documentation.

Step 8: Staff provides written notification to all individuals within the proposed district and within a 200 feet radius of the proposed district that the area has been proposed as a local historic district. Staff also provides educational material explaining what a local historic district is and is not. Additionally, a schedule of public workshops/ hearings is enclosed.

Step 9: At public hearing staff provides educational materials, conducts workshops to demonstrate how the historic district will affect property owners.

Step 10: Individuals at hearing may ask questions, sign 
proposals for or against the historic district.

Step 11: Draft ordinance and map is prepared for the establishment of the local historic district.

Step 12: Series of public hearings is conducted. property owners and interested individuals testify for or against the district. Those testifying must state their relationship to the district.

Step 13: City Council introduces the ordinance.

Step 14: Within ten days of the passage of the ordinance, the Historic District Commission shall send by registered mail a notice stating the fact of said district and a brochure similar to those being prepared through the Certified Local Governments Program to the owner of record and any person having a recorded legal interest in said property.

The established time frame for this recommendation is shortterm. The current local historic designation process has receives much criticism from individuals and groups wishing to establish a local historic district, thus this process should be amended as soon as possible.

Recommendation 4: Develop one page summary sheets to explain important aspects of the Bistoric District Commission and the local historic districts.

The steps to developing these summary sheets are:

Step 1: Inventory current informational brochures, pamphlets and handouts distributed by the Commission.

Step 2: Determine information shortcomings.

Step 3: Assign staff or a Committee to prepare information 
summary forms that should be handed out to property owners and other interested parties.

Step 4: Establish funding sources for the publication and distribution of these informational tools.

The time frame for this activity is ongoing. The Commission should always seek to educate historic district property owners and other interested parties. Organizations, such as PPS and the Rhode Island Historical Preservation Commission may be willing to assist the Commission in this endeavor.

\section{Recommendation 5: Develop a question and answer brochure to be distributed to individuals and organizations concerned with or affect- od by the designation of local historic districts. Exhibits 1 and 2 are examples of question and answer brochures.}

The Commission should review their records to determine the types of questions frequently asked by local historic district property owners and other interested parties and develop appropriate responses for these questions. The time frame for implementation of this recommendation is immediate.

Recommendation 6: Use graphic illustrations and provide definitions for key design criteria such as scale, massing, hoight. Exbibits 3-7 provide examples of graphic iliustrations.

The Commission should assign staff or a committee to 


\section{Local Historic Districts -Questions and Answers}

\section{Q. What is a Local Bistoric District and what is it's purpose?}

A. A Local Historic District is an area of historic, architectural. and/or cultural importance that is protected by a preservation zoning law. It preserves and protects historic structures and encourages new design which is compatible with the existing buildings. Local Historic Districts have proven to be a highly successful way to provide for change and growth. while preserving the character of the area.

\section{Q. Who will administer the district?}

A. The Providence Historic District Commission will administer the Historic District, serving as a design review board. Commissioners come from the architectural profession, preservation organizations. the real estate community, property owners within Local Historic Districts and the Providence City Council. All members of the Commission are appointed by the Mayor and serve on a volunteer basis.

Q. Do all changes require review by the Historic District Commission?

A. .io. Ordinary maintenance, repair or replacement of esisting features which do not change the esterior design or appearance do not require review by the full Commission. The Commission staff can authorize this type of routine maintenance and repar.

Q. Will I be forced to do extra maintenance on my house?

A. Vo. The Frovidence Historic District Commission onlv has authority over proposed changes. The ordinary mantenance and reparr of your house will still be under the authority of the divison of Code Eniorcement as it is now.

Q. Will I be told what color to paint my house?

A. Vio

Q. I may want to redesign the interior of my home. Will I have to get permission Irom the Providence Historic District Commission?

A. Lis. The Commission only deais zilth eyterior changes.

Source: The Elmwood Foundation for Architectural \& Historical Preservation. 


\section{Q. Will demoliton be prohibited?}

A. Approval would be required for demolition in the Historic District. This will assure residents of the area that important historical structures will not be arbitrarily destroyed without public discussion.

Q. Does inclusion within a Local Historic District curtail the ability to use or sell property?

A. No. A Historic District deals only with exterior design. In fact, District designation has $k$ zen shown to benefit both buyers and sellers. Geayse it provides an assurance that a neighborhood will retain its character. The establishment of a District does not prevent change from occuring, nor does it prevent new construction.

\section{Q. Will businesses be allowed in the Historic District?}

A. Yes. The current zoning lats already control what types of businesses can be established. A Local Historic District would merely strengthen the current laws by requiring businesses and structures to be of a scale and type that would be appropriate.

\section{Q. Must new buildings in the Historic District be imitations of historic} buildings.

A. No. The intent of the ordinance is to make new construction or alterations harmonize with the existing buildings in the area and to prevent serious incongruities, not to require copies of historic buildings.

Q. Who can I call to get more information?

A. The City of Providence not has two preservation planners. Cathy Cavanaugh and Hary Turkel, who can anster your questions. Both Cathy and Mary can be reached at the Depariment of Plannirg and Development at $351-4300$.

SOURCE: Elmwood Foundation for Architectural \& Historical Preservation. 
EXHIBIT TWO:

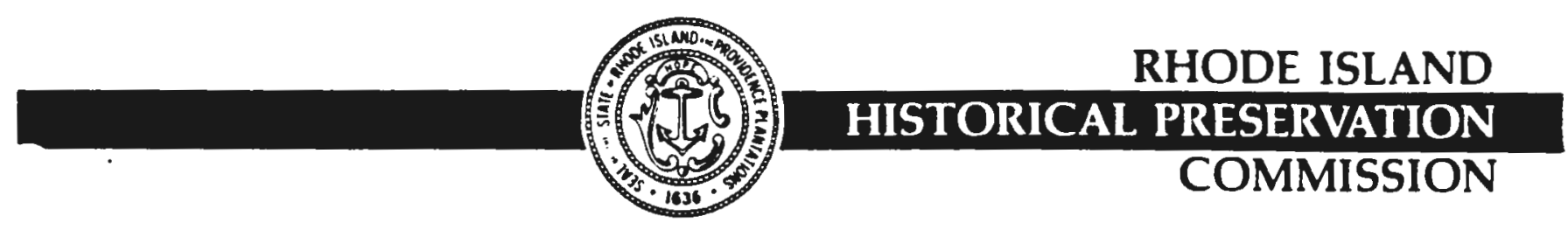

\section{WHAT IS HISTORIC DISTRICT ZONING?}

\section{What does historic district zoning do?}

Local historic districts are special zoning areas created by a community to help save historic buildings and to preserve a special sense of time and place. By establishing local historic district commissions and instinuting design review, Rhode Island communities monitor and guide construction activity in their historic areas.

\section{Doesn't listing in the National and State Reyisters of Filstoric Finces provide enough protection?}

National and State Register listing provides protection only when public funds or government licenses are involved. Local historic district zoning reviews owners' private actions such as changes to the outside of buildings as well as review of new construction.

National and State Register listing makes historic properties eligible for grants, tax credits, and low-interest loans, when such programs are available; some commnnities allow for local property tax relief for restoration of historic houses.

How is historic district zoning established in a commanity?

The city or town council must pass an ordinance to establish a historic district commission and to identify those areas reviewed by the bistoric district commission. Depending on the form of local government, members of the commission are appointed by mayors of cities and presidents of town councils.

How does local historic district zoning work?

In a local historic district, all exterior construction, alteration, or repair must be approved by the historic district commission, which usually holds monthly public meetings. The commission's review ensures maintenance of the architectural character of the buildings while accommodating necessary change. Commissions have written procedures and guidelines.

Does the historic district commission require me to make chnnges to my property?

No. When you decide to make changes, the historic distriat commission will review the project. Application for a building permit activates the review process.

Con the historic district commission tell me what color to paint my house?

No. Historic distriat commissions do not review paint colors. You may, of course, ask for and receive advice on paint colors, but you are under no obligation to seek or follow such advice.

Will the approval process delay my project?

The review process typically calls for submission to the historic district commission of an application with clear information and drawings as needed. In some communities, the application is reviewed by profescional staff before going to the full commission; such preliminary review may iron out problems and speed the process. Minor alteratioas and replacements in kind may be approved by staff alone. The application is reviewed at regular monthly meetings of the commission. After any adjustments, the approved application is stamped for submission to the building inspector for a building permit. Successful review and approval are often accomplisbed at one meeting. If adjustments to the proposal are recommended, review may require several meetings. The historic district commission may hold special meetings if quicker action is needed. 
Will the historic district commisslon require me to undertike a more expeastve profoct?

Historic distridt commissions are sensitive to cost considerations, but their primery concern is compatibility with existing historic architecture. Commissions can, however, draw on a large body of knowledge to advise bomeowners on the most cost-effective methods of construction or replacement.

What hoppens if a property owner disagress with the dedision of the historic district commisaloe?

Decisions of the historic distriat commission may be appealed to the local zoning bourd of review, which judges the historic distriat commission's decision for following correct procedures and making a decision based on the evidence presented. Decisions of the zoning board of review may be appealed in atate superior court.

Does histork district 2oning change erinting zoning?

No. Local historic districts are overlay zones added to the existing zoning. Historic distria zoaing often tends, however, to reinforce existing zoning.

Does historic district 2oning ralse property taxes?

No. Property taxes are based on fair-market value, which is determined by real-estate market forces and includes considerations of location, condition, size, and amenities. In Rhode Island, neighborhoods protected by historic distriat zoning have generally enjoyed stability and long-term improvement to property values.

What is the malo disadvantage of historic district zoning?

Preparing applications to the historic distria commission may require extra time and effort before construction begins. The time and effort on the part of the homeowner is usually offset, however, by the expertise and constructive review of the historic distriat commission and staff and a more successful construction project.

What ts the maln advantage of historic district zoning?

Most people who live in historic districts want the architectural character of their neighborhood to be preserved. Historic distric zoning protects a neighborhood's historic architecture, which largely defines its sense of place. Thoughtless alterations to historic buildings can forever erode property values and destroy the qualities that make a aeighborhood appealing. Historic distriat zoning places the stewardship of a community's historic properties in its own hands; decisions about the future of the community are made by those who most benefit, the local residents.

Where can I get more information? information.

If your town already has a historic distriat commission or preservation society, these can be good sources of

Additional information on all aspects of historic preservation is available from the Rhode Island Historical Preservation Commission. The RIMPC is the state office which identifies and protects historic buildings and districts and archacological sites.

Source: Rhode Island Historical Dreservation Commission, Fact ractshidz Sheets. 


\section{EXHIBIT THREE: GRAPHIC ILLUSTRATIONS}

\section{HEIGHT}

Consider-Relating the overall height of new construction to that of adjacent structures. As a general rule, construct new buildings to a height roughly equal to the average height of existing buildings from the historic period on and across the street.

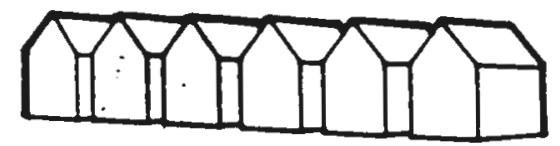

Avoid-New construction that greatly varies in height (too high or too low) from older buildings in the vicinity.

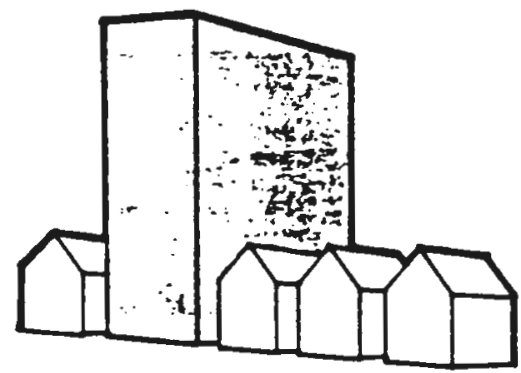

\section{SCALE}

Consider-Relating the size and proportions of new structures to the scale of adjacent buildings. A though much larger than its neighbors in terms of square footage, the building shown maintains the same scale and rhythm as the existing buildings.

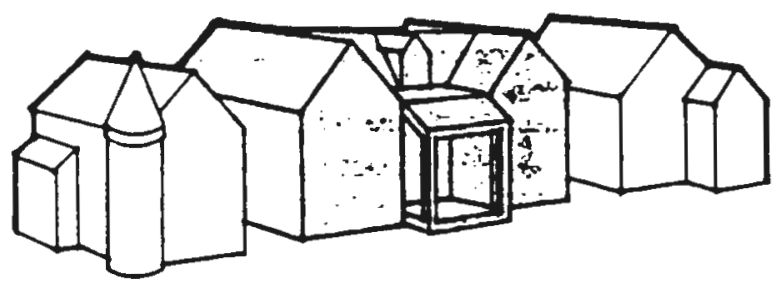

Avoid-Buildings that in height, width, or massing violate the existing scale of the area. The new building shown here disrupts the scale and rhythm of the streetscape, although it might be appropriate in a different location.

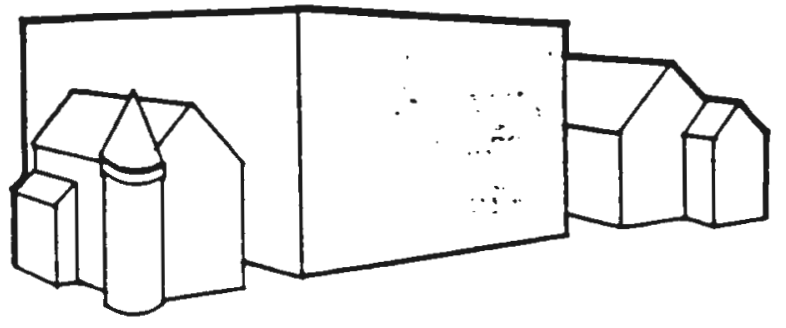

\section{MASSING}

Consider - Breaking up uninteresting boxlike forms into smaller, varied masses such as are common on most buildings from the historic period. Variety of form and massing are elements essential to the character of the streetscape in historic districts.

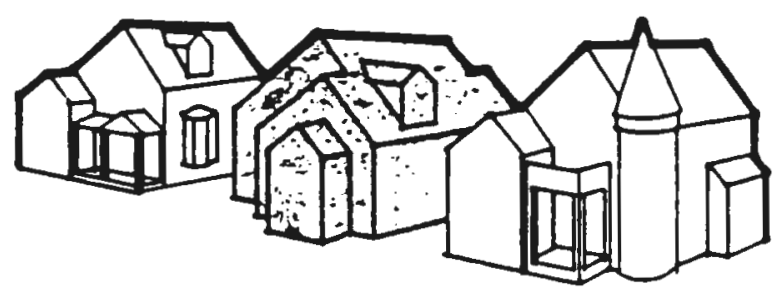

Avoid-Single, monolithic forms that are not relieved by variations in massing. Boxlike facades and forms are intrusive when placed in a streetscape of older buildings that have varied massing and facade articulation.

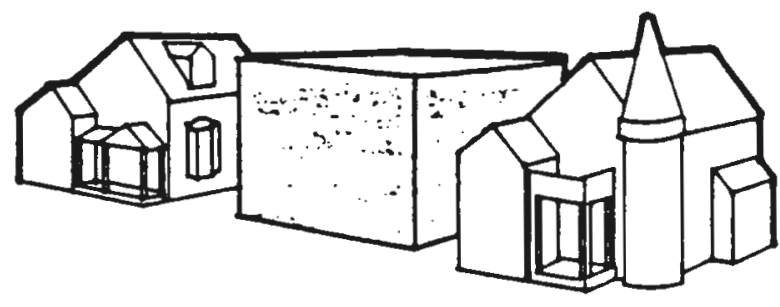

\section{DIRECTIONAL EXPRESSION}

Consider-Relating the vertical, horizontal, or nondirectional facade character of new buildings to the predominant directional expression of nearby buildings. Horizontal buildings can be made to relate to the more vertical adjacent structures by breaking the facade into smaller masses that conform to the primary expression of the streetscape.

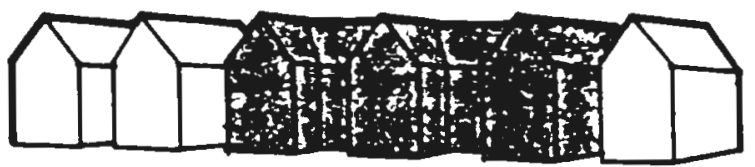

Avoid-Strongly horizontal or vertical facade expressions unless compatible with the character of structures in the immediate area. The new building shown does not relate well to either its neighbors or to the rhythm of the streetscape because of its unbroken horizontal facade.

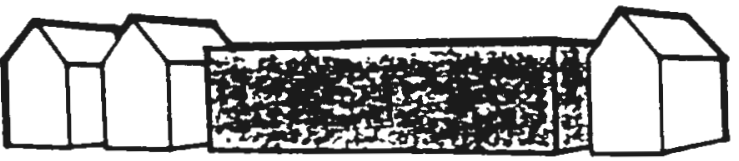
Dg 112 .

Source: Bowsher, Desian Review in 


\section{SETBACK}

Consider-Maintaining the historic facade lines of streetscapes by locating front walls of new buildings in the same plane as the facades of adjacent buildings. If exceptions are made. buildings should be set back into the lot rather than closer to the street. If existing setbacks vary. new buildings should conform to historic siting patterns.

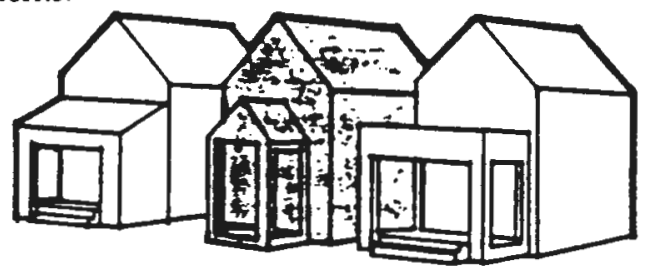

Avoid-Violating the existing setback pattern by placing new buildings in front of or behind the historic facade line. Avoid placing buildings at odd angles to the street. unless in an area where diverse siting already exists, even if proper setback is maintained.

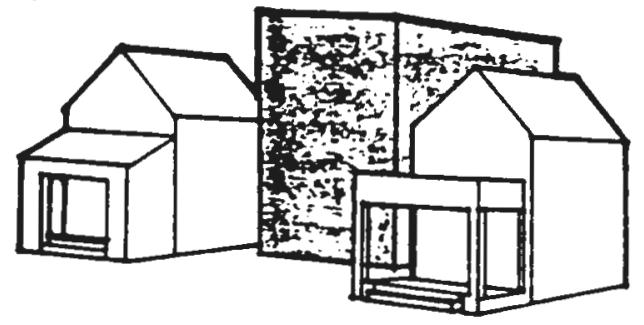

\section{PLATFORMS}

Consider-The use of a raised platform is a traditional siting characteristic of most of the older buildings in Salt Lake City. This visual "pedestal" is created by retaining walls and terracing up to the building or by high foundation walls and stepped entries.

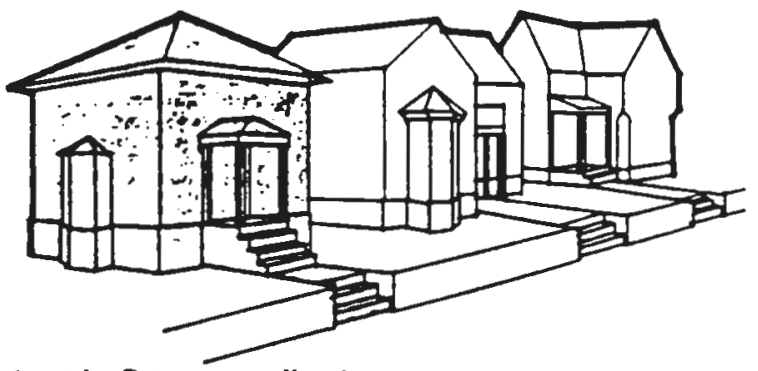

Avoid-Bringing walls of new buildings straight out of the ground without a sense of platform. i.e.. without maintaining the same entry height as neighboring buildings. Such structures seem squat, visually incomplete, and do not relate well to their elevated neighbors. Also avoid leveling off terraced siopes or removing retained platforms.

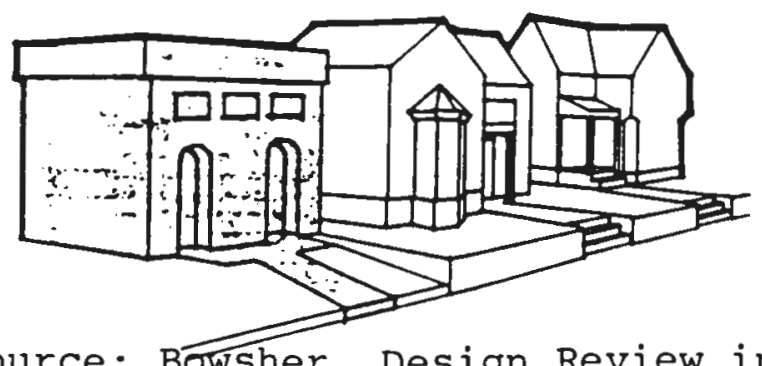

\section{SENSE OF ENTRY}

Consider-Articulating the main entrances to the building with covered porches, porticos, and other pronounced architectural forms. Entries were historically raised a few steps above the grade of the property and were a prominent visual feature of the street elevation of the building.

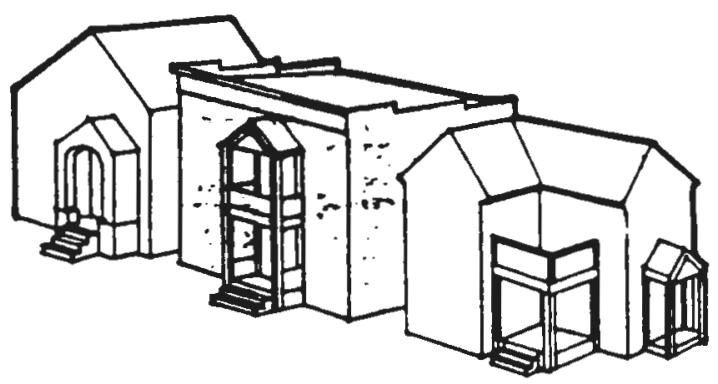

Avoid-Facades with no strong sense of entry. Side entries or entries not defined by a porch or similar transitional element result in an incompatible "flat" first-floor facade.

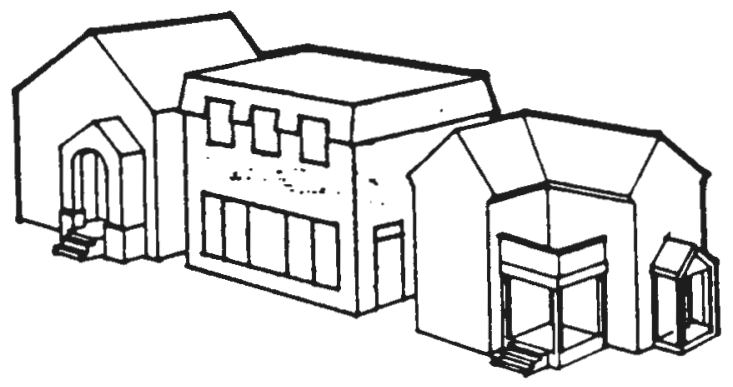

\section{ROOF SHAPES}

Consider-Relating the roof forms of the new buildings to those found in the area. Although not entirely necessary, duplication of the existing or traditional roof shapes, pitches, and materials on new construction is one way of making new structures more visually compatible.

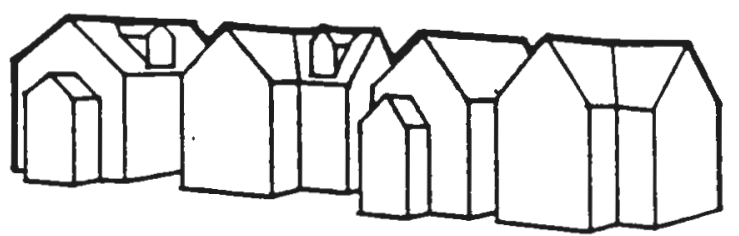

A void-Introducing roof shapes, pitches, or materials not traditionally used in the area.

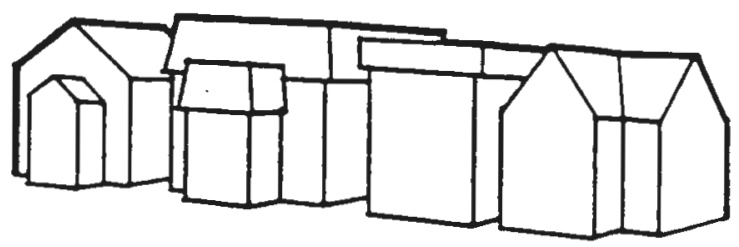

Source: Bôwher, Design Review in Local Historic Districts, pg. 113. 


\section{n RHYTHM OF OPENINGS}

Consider-Respecting the recurrent alternation of wall areas with door and window elements in the facade. Also consider the width-to-height ratio of bays in the facade. The placement of openings with respect to the facade's overall composition, symmetry, or balanced asymmetry should be carefully studied.

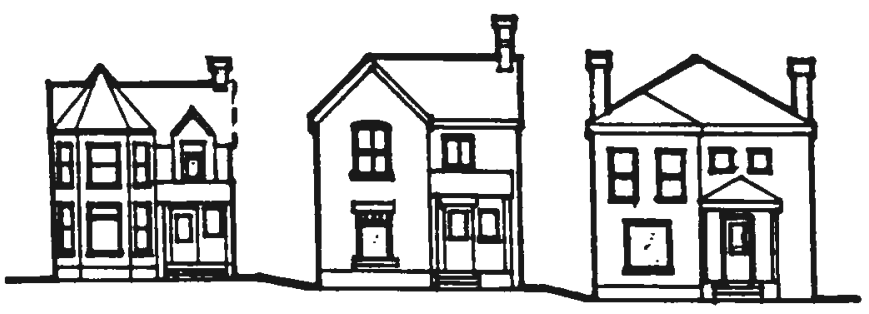

Avoid-Introducing incompatible facade patterns that upset the rhythm of openings established in surrounding structures. Glass walls and window and door shapes and locations shown in the example are disrespectful to the adjoining buildings.

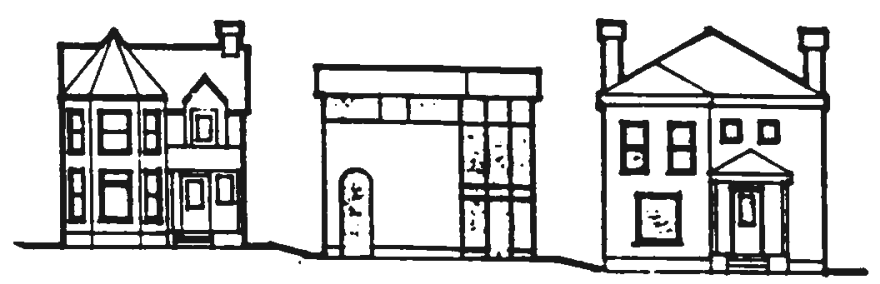

\section{IMITATIONS}

Consider-Accurate restoration of or visually compatible additions to existing buildings, and. for new construction, contemporary architecture that well represents our own time, yet enhances the nature and character of the historic district.

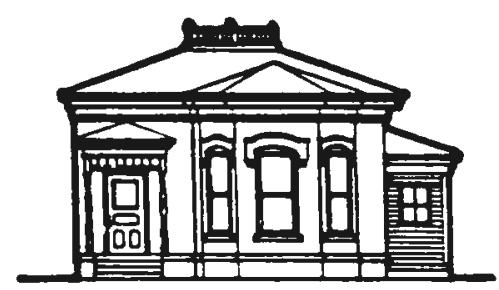

Avoid-Replicating or imitating the styles, motifs, or details of older periods. Such attempts are rarely successful and, even if done well, present a confusing picture of the true character of the historical area.

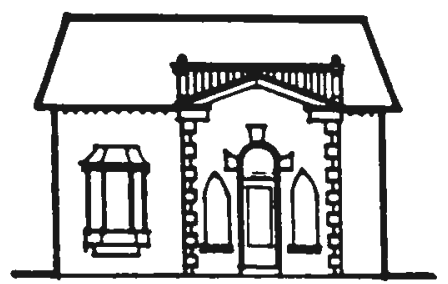


:

The materials of concern to historic distric commissions are only those aterials affecing the finished, or excerior, appearance in many districts materials uch as wood siding or brick predominace If a district has a concentration of a articular finish, a new material which contrass suongly an interrupt the district's armony.
matrRIALS AND PINISHES w ow. The Artanas Hiscoric Preservation Program does not recommend the appliction of aruficial siding over original materials. The AHPP official policy on this subject sotes: "A structure is historic becuse its materials and the crifsmanship reflected in is construccion are angible and irreplaceable evidence of our cutural heriage To the degree that they conceal the original building fabric subsriture materiais such as aluminum and vinyl sidings will alway suberact from the basic integrity of historialty and architecurally signifiant buildings. Therefore buildings which have been altered by the applicarion of arcificial siding will be considered ineligible for National Register liscing."

Source: Desiqn RFview in Local Historic Districts, pg. 115. 
Josely related to materials the surface texwure of a building indudes the small projections on the hades, such as chose formed by porches. windows and other deails in a district with varying facde textures, a very flatly taced building forms a sharp break.

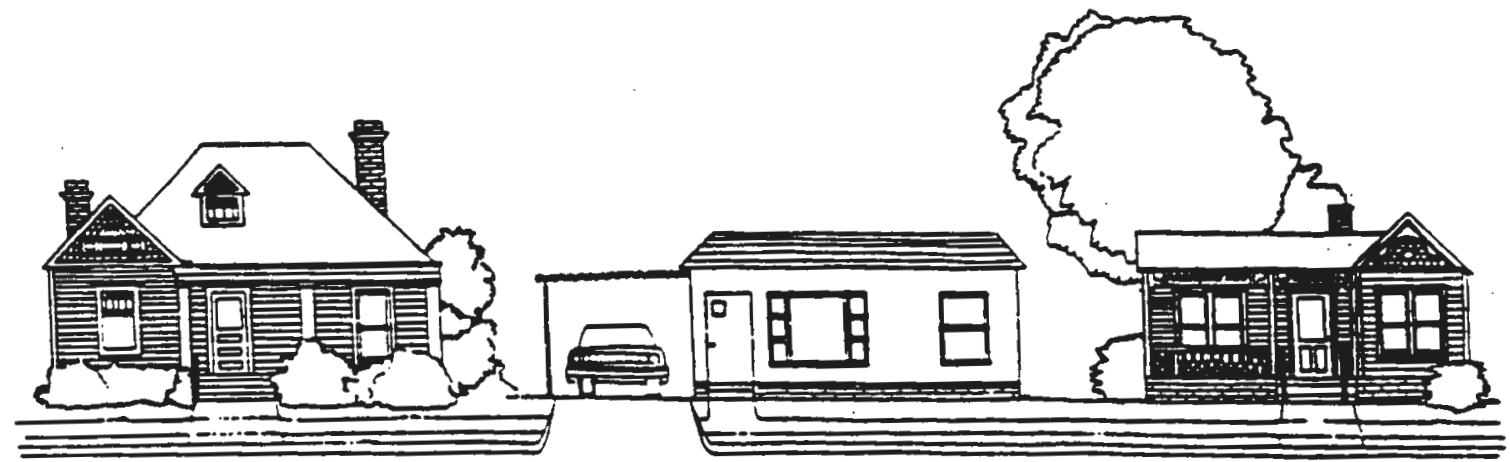

Note how this building lades the deailing and vistal imerest of the exisoing neighboring buildingt

The placement of windows and doors on the building's facde contribure wo the irectural character by setcing up thrchms within the building itself The patterm

patrans en is an imporant part of the orienation of the building.

One of the most imporant facets of nineteench and earty twentiecth century neighbothoods is that they are all oriented to the sureet. The front entry faces the strees and there is a pronounced pattem on the sureet facde
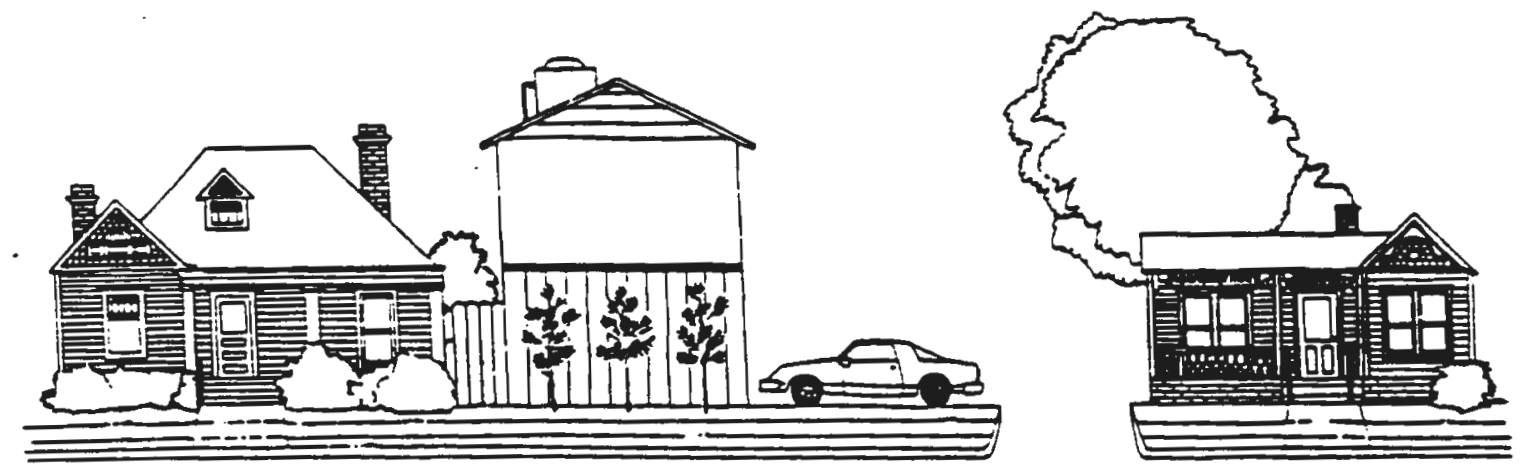

Note how the onentavion and the sale of the new building in the center contrats with that of the exwang neighboring buildings.

Source: Bowsher, Desian Review in Local Historic Districts, pg.116. 
identify those terms and design criteria which may confusing to local historic district residents. The staff or review committee should review graphic illustrations used by other commissions or develop new illustrations to be used in the current design guidelines of the Commission. The time frame for this activity is midterm.

Recommendation 7: The Commission should be more accessible to residents of the local bistoric districts.

The Commissionn can significantly increase its accessibility by conducting workshops and other activities in the local historic districts. The Commission should first gather information from local historic district residents to determine their interests and needs. This can be accomplished through a mail survey or through a public meeting. The time frame for this activity is immediate. 
REFERENCES 


\section{REFERENCE8}

Buckhurst Fish Hutton and Katz Inc., 1991. A Plan For Preservation, City of Providence:Rhode Island.

Bowsher, Alice Meriwether, 1983. Design Review in Historic Districts, National Trust for Historic Preservation: District of Columbia.

City of Providence, 1992. Providence 2000: The Comprehensive Plan, City of Providence:Rhode Island.

City of Providence, 1991. City of Providence Zoning Ordinance, City of Providence: Rhode Island.

Providence Preservation Society 1982. The Armory District:Harmonious Streetscapes, PPS:Rhode Island.

Providence Preservation Society 1983a. Broadway: A Victorian Boulevard, PPS:Rhode Island.

Providence Preservation Society 1983b. Elmwood:A Victorian Neighborhood, PPS:Rhode Island.

State of Rhode Island, 1956. Rhode Island General Laws 4524.1., State of Rhode Island: Rhode Island.

State of Rhode Island, Rhode Island Historical Preservation Commission, 1986. Providence: A Citywide Survey of Historical Resources Statewide Historical Preservation Report, $p-p-7$, RIHPC: Rhode Island.

State of Ohio, 1981. opportunities for Bringing People Back Downtown, state of Ohio:Ohio.

The Providence Historic District Commission 1992a. Standards and Guidelines for the Armory, Broadway, College Hill, South Elmwood and Stimson Avenue Historic Districts, City of Providence: Rhode Island.

The Providence Historic District Commission 1992b. Rules and Regulations, City of Providence:Rhode Island.

Ziegler, Arthur P., 1974. Historic Preservation in Inner City Areas: A Manual of Practice, Ober Park Associates: Pennsylvania. 
APPENDICES 
APPENDIX 1: DEEINITIONS 
GENERAL PRESERVATION DEFINITIONS

1. Acquisition - Is defined as the act or process of acquiring fee title or interest other than fee title of real property (including the acquisition of development rights or remainder interest).

2. Alteration - An act that changes one or more of the exterior architectural features of a structure or its appurtenances, including but not limited to the erection, construction, reconstruction, or removal of any structure or appurtenance.

Major Alteration - An alteration which affects the historic, cultural, or architectural integrity, interpretability, or character of a building, structure, site or district.

Minor Alteration - An alteration which does not significantly affect the historic, cultural, or architectural integrity, interpretability or character of a building, structure, site or district.

3 Appurtenances - Features other than primary or secondary structures which contribute to the exterior historic appearance of a property, including but not limited to paving, doors, windows, signs, materials, decorative accessories, fences, and historic landscape features.

4. A Certificate of Appropriateness - Is the certificate issued to a property owner by the Historic District Commission upon approval of an owners request to make exterior changes to his/her property.

5. Contributing Building/ Structure/ Site - A building, structure or site which reflects the visual integrity or interpretability of a historic district. A contributing building is not necessarily "historic" 150 years old or older). A contributing building may lack individual distinction but may add to the historic district's status as a significant and distinguishable sociocultural entity.

6. Demolition - An act or process that destroys or razes a structure or its appurtenances in part or in whole, or permanently impairs its structural integrity.

7. Demolition by Neglect - The ruin of a structure or its 
appurtenances by neglect of necessary maintenance and repairs.

8. Elevation - A drawing showing the front, rear, or side face of a structure, in a vertical plane. Also refers to the actual front, rear or side of a structure. Elevations may show the exterior or interior of a structure and are often described as facing a compass direction (north, south, east, west).

9. Existing Condition - Occurring or found on a structure or site before any exterior work begins. May include original features and previous alterations.

10. Facade - The exterior face of a building which is the architectural front, sometimes distinguished from the other faces by elaboration of architectural or ornamental details.

11. Fenestration - The proportion and size of window and door openings and the rhythm and order in which they are arranged.

12. Height - The vertical distance from the average grade level to the average level of the roof.

13. Historic - In reference to features of a structure or site, those which are important to the history of the building. original features are considered historic; later alterations may be considered historic if they have gained significance over time.

14. In Kind/Match - In reference to repairs or replacement, the finished condition will be the same in all respects as the previous condition. "Repair to match existing" shall not change the material design, dimensions, configuration, texture or visual appearance of an element, excluding damage deterioration, discoloration, or dirt. "Replacement in kind to match existing" means the new element shall have the same material, design, dimensions, configuration, texture and visual appearance as the element being replaced, excluding damage deterioration, discoloration, or dirt.

15. Landscape - Describes the overall characteristics of the district's setting and its repetitive elements.

16. Light - In reference to windows and doors, a pane of glass. "True divided lights" refers to the separation of individual small panes of glass by muntin bars, so that the muntins appear to penetrate the vertical plane of the glass. Also refers to a source of illumination. 
17. Moving - The relocation of a structure or portion thereof on its site or to another site.

18. New Construction - The act of adding to an existing structure or erecting a new principal or accessory structure or appurtenances to a structure, including but not limited to buildings, extensions, outbuildings, fire escapes, and retaining walls.

19. Mass - The term mass combine all three dimensions (length, height, and depth). A building is often composed of many masses, hence the term massing, which is often used to describe the form or shape of structures like cathedrals.

20. Non-Contributing Building/Structure/Site - A building, structure or site which detracts from the visual integrity or the interpretability of a historic district.

21. Ordinary Maintenance and Repair - Work meant to remedy damage or deterioration of a structure or its appurtenances, which will involve no change in type of materials, dimensions, design, configuration, color, texture or visual appearance.

22. Original - Occurring or found on a structure or site since its initial construction.

23. Preservation - Keeping an existing building in its current state by a careful program of maintenance.

24. Primary Elevation - The exterior face of a building which fronts on a street. primary elevations are often distinguished by elaborate architectural or ornamental details. Most buildings have one primary elevation, but corner buildings and buildings occupying large of multiple lots may have two or more. In such cases, those faces fronting on sperate streets which measure 30 or more feet in width, measured from property line to property line, shall be considered primary elevations.

25. Protection - Is defined as the act or process of applying measures designed to affect the physical condition of a property by defending or guarding it from deterioration, loss or attack, or to cover or shield the property from danger or injury. In the case of buildings and structures, such treatment is generally of a temporary nature and anticipates future historic preservation treatment; in the case of archeological sites; the protective measure may be temporary or permanent. 
26. Proportions - The dimensional relationship between one part of a structure or appurtenance and another. Facade proportions involve relationships such as height to width, the percent of the facade given to window and door openings, the size of these openings, and floor to ceiling heights. Often described as a ratio, proportions may be vertical (taller than wide), horizontal (wider than tall) or non-directional (equally tall and wide).

27. Reconstruction - Is defined as the act or process of reproducing by new construction the exact form and detail of a vanished building, structure, or object, or a part thereof, as it appeared at a specific period of time.

28. Rehabilitation - Making a structure sound usable again, through repair or alteration, without attempting to restore to any particular period appearance but respecting and preserving those portions and features of the property which are significant to its historic, architectural and cultural values.

29. Restoration - Repairing or re-creating the original architectural elements in a building so that it closely resembles the appearance it had at some previous point in time.

30. Scale - The relative proportion of a building to neighboring building, or of a building to a pedestrian observer.

31. Setback - The horizontal distance between a structure's vertical planes and a reference line, usually a property line.

32. Secondary Elevation - Generally, the side and rear exterior faces of a building, especially those facing service areas, alleys or minor streets (less than 30 feet wide, measured from property line to property linel.

33. Stabilization - Is defined as the act or process of applying measures designed to reestablish a weather resistant enclosure and the structural stability of an unsafe or deteriorated property while maintaining the essential form as it exists at present.

34. Structure - Anything constructed or erected, which requires permanent or temporary location on the ground or attachment to something having a location on the ground, including but not limited to buildings, gazebos, billboards, and outbuildings.

35. Visibility From a Public Way - Able to be seen from any 
public right-of-way (such as a street or sidewalk, excluding interstate highways, air corridors and waterways), or other place, whether privately or publicly owned, upon which the public is regularly allowed or invited to be. Visibility may be judged from inside the district boundaries and/or within 200 feet outside the boundaries. Visibility may not be enhanced by optical devices or instruments, such as binoculars or a telephoto lens.

\section{DEFINITIONS FOR STOREFRONT COMPONENTS:}

1. Awning - A roof-like cover extending over a window or door, intended to provide the pedestrian protection against sun, rain and wind. Awnings are usually made of soft canvas or other fabric and may be fixed or adjustable.

2. Cornice - A horizontal projecting band that caps an architectural composition.

3. Display window - Large areas of glass within the storefront opening. The display window is used to show merchandise and provide a means of interaction between the public outside and the business inside.

4. Entrance Area - The point of entry into the storefront, traditionally recessed to provide additional window display, weather protection, and protection from the outward swing of a door. made up of the following components: door, transom window above the door, side lights or display windows, floor area.

5. Lintel - A horizontal structural element (usually a steel beam covered by masonry) which spans the storefront opening and supports the upper portion of the facade wall above it. Also defines the upper boundary of the storefront.

6. Lower Window Panels - The solid panels (usually wood) below the display window. These panels provide the base support for the display window frame.

7. Ornamentation - Decorative objects which are used to increase the beauty of the facade.

8. Sign - A lettered board or other display, mounted either parallel or perpendicular to the building face somewhere above the display window, used to identify or advertise a place of business. The sign is one of the most important components on the facade because it is the 
first perception of the business image. A window sign is applied to or located behind glass.

9. Storefront Columns - Slender vertical elements within the storefront opening which will help support the lintel.

10. Support Wall or Pier - Large vertical masses on either side of the storefront opening which support the lintel and define the right and left boundaries. In large buildings support walls (piers) define bays which may contain individual storefronts and/ or display windows.

11. Transom - Glass panel above a horizontal frame bar (transom bar) atop the display window or door, used to allow more light into the store interior.

12. Upper Facade - The mostly solid part of the wall above the display window. may be a plain surface on a one story building, or contain rows of windows defining the number and location of floors in a multistory building. May include decorative bands or patterns. Usually presents the largest surface of color on the building, since the first floor is mostly glass. 
APPENDIX 2: STATE ENABIING IEGISIATION 
CHAPTER 24.1

HISTORICAL AREA ZONING

Section.

45-24.1-1. Declaration of purpose.

45-24.1-1.1. Definitions.

45-24.1-2. Historic district zoning authorized.

45-24.1-3. Creation of commission authorized-Membership appointment--Term of office.

45-24.1-3.1. Present appointments unaffected.

45-24.1-4. Permit required to construct, alter or demolish

structure--Application--Powers of comission.

45-24.1-5. Avoiding demolition through owner neglect.

45-24.1-6. Public meetings.

45-24.1-7. Appea1s certificate of appropriateness or rejection

45-24.1-7.1 Right of Appeals.

45-24.1-7.2. Scope of review by zoning board.

45-24.1-8. Exceptions to application of chapter.

45-24.1-9. (Changed to 45-24.1-7.2)

45-24.1-10. Enforcement.

45-24.1-11. - 45-24.1-19. (Repealed)

45-24.1-20. Preservation of historic structures in Pawtucket.

45-24.1-21. Preservation of historic structures in Narragarisett.

45-24.1-1. Declaration of purpose.- The preservation of structures of historic and architectural value and historic cemeteries wherever located within a city or town are hereby declared to be a public purpose and the city council of any city and the town council of any town shall have the power by ordinance to regulate the construction, alteration, repair, moving, and demolition of these structures within the limits of the city or town. It is recognized that the purpose of such ordinance is to:

(a) safeguard the heritage of the city or town by preserving a district in a city or town which reflects elements of its cultural, social, economic, political, and architectural history;

(b) stabilize and improve property values in that district;

(c) foster civic beauty;

(d) strengthen the local economy;

(e) promote the use of the historic districts for the education, pleasure, and welfare of the citizens of the city or town;

(f) provide, where feasible, that in these historic districts housing, including but not limited to, limited equity cooperative housing, be made available to low and/or moderate income residents. 
45-24.1-1.1. Definitions.--The following terms shall have the following respective meanings unless a different meaning clearly appears from the context:

(1) "Alteration": An act that changes one or more of the exterior architectural features of a structure or its appurtenances, including but not limited to the erection, construction, reconstruction, or removal of any structure or appurtenance.

(2) "Appurtenances": Features other than primary or secondary structures which contribute to the exterior historic appearance of a property, including but not limited to paving, doors, windows, signs, materials, decorative accessories, fences, and historic landscape features.

(3) "Certificate of appropriateness": A certificate issued by a historic district commission established under this chapter indicating approval of plans for alteration, construction, repair, removal, or demolition of a structure or appurtenances of a structure within a historic district. Appropriate for the purposes of passing upon an application for a certificate of appropriateness means not incongruous with those aspects of the structure, appurtenances, or the district which the commission has determined to be historically or architecturally significant.

(4) "Construction": The act of adding to an existing structure or erecting a new principal or accessory structure or appurtenances to a structure, including but not limited to buildings, extensions, outbuildings, fire escapes, and retaining walls.

(5) "Demolition": An act or process that destroys a structure or its appurtenances in part or in whole.

(6) "Historic district": A specific division of a city or town as designated by ordinance of the city or town pursuant to this chapter. A historic district may include one or more structures.

(7) "Removal": A relocation of a structure on its sice or to another site.

(8) "Repair": A change meant to remedy damage or deterioration of a structure or its appurtenances.

(9) "Structure": Anything constructed or erected, the use of which requires permanent or temporary location on or in the ground, including but not limited to buildings, gazebos, billboards, out-buildings, decorative and retaining walls, and swimming pools.

45-24.1-2. Historic district zoning authorized.-For such purposes each city and town shall have the authority to establish, change, lay out, and define districts which are deemed to be of historical or architectural value in the same manner as those cities and towns are presently empowered to establish or change areas and classifications of zoning. 
45-24.1-3. Creation of commission authorized--Membership appointment--Term of office.--In order to carry out the purposes of this chapter the city council of any city or the town council of any town shall have the authority to create a commission to be called the historic district commission. The membership of a commission in a city shall consist of seven (7) qualified members and in a town shall consist of not less than three (3) nor more than seven (7) qualified members whose residence is located in the city or town, provided, that the historic district commission of the city of Newport shall consist of nine (9) qualified members, and provided, that the historic district commission of the city of Providence shall consist of thirteen (13) qualified members two (2) of whom shall be members of the city council elected by the city council from its councilmanic members to serve for a term of four (4) years and two (2) of whom shall be members of the general assembly elected from the city of Providence, one to be appointed from the senate by the senate majority leader and one to be appointed from the house by the speaker. In a city the members shall be appointed by the mayor, except as hereinbefore provided in the case of the historic district commission of the city of Providence, and in a town by the president of the town council. The appointed members of the commission shall be appointed for three (3) year terms except the initial appointments of some of the members shall be for less than three (3) years to the end that the initial appointments shall be staggered and so that subsequent appointments shall not reoccur at the same time. Any city or town shall have the right to name an auxiliary member of said commission appointed in addition to the regular members of the commission, which auxiliary member shall sit as an active member, upon the request of the chairman when and if a regular member of the commission is unable to serve at any meeting of the commission. Appointed members of the commission shall be eligible for reappointment and upon the expiration of their term shall continue to serve until replaced unless otherwise provided for in local law. In the event of a vacancy on the commission interim appointments of appointed members may be made by the appointing authority to complete the unexpired term of the position. Duly organized and existing preservation societies may present to the appointing authority of a city or town a list of qualified citizens from which list the appointing authority may seiect members of the comnission for his or her respective city or town.

45-24.1-3.1. Present appointments unaffected.--Nothing contained in Section 45-24.1-3, shall in any way alter any other part or provision of this title, chapter, or section or any appointments heretofore or hereafter made thereunder, all of which remain in full force and effect.

45-24.1-4. Permit required to construct, alter or demolish structure--Application--Powers of commission.--

(1) The commission shall, within twelve (12) months of the date the local historic district zoning ordinance takes effect:

(a) adopt and publish all rules and regulations necessary to carry out its functions under the provisions of this chapter; and

(b) publish such standards as necessary to inform historic district residents, property owners, and the general public of those criteria by which the commission shall determine whether to issue a certificate of appropriateness. The commission may amend these standards as reasonably necessary, and it shall publish all such amendments. 
eliminated by economic means available to the owner, including sale of the structure to any purchaser willing to preserve such structure or unless the commission votes to issue a certificate of appropriateness for the proposed construction, alteration, repair, removal or demolition, the comission shall file with the building official or duly delegated authority its rejection of the application. In the absence of a change in the structure arising from casualty, no new application for the same or similar work shall be filed within one year after the rejection.

(6) In the case of any structure deemed to be valuable for the period of architecture it represents and important to the neighborhood within which it exists, the commission may file with the building official or other duly delegated authority its certificate of appropriateness for an application if any of the circumstances under which a certificate of appropriateness might have been given under subsection (5) are in existence or if:

(a) Preservation of the structure is a deterrent to a mojor improvement program which will be of substantial benefit to the community;

(b) Preservation of the structure would cause undue or unreasonable financial hardship to the owner taking into account the financial resources available to the owner including sale of the structure to any purchaser willing to preserve such structure; or

(c) The preservation of the structure would not be in the interest of the majority of the community.

(7) When considering an application to demolish or remove a structure of historic or architectural value, the commission shall assist the orner in identifying and evaluating alternatives to demolition, including sale of the structure and its present site. In addition to any other criteria the commission also shall consider whether there is a reasonable likelihood that some person or group other than the current owner is willing to purchase, move, and preserve such structure and wherher the owner has made continuing, bonafide and reasonable efforts to sell the structure to any such purchaser willing to move and preserve such structure.

(8) No less then fifteen (15) days after receiving an application to demolish or to remove an historic cemetery, the commission shall forward the application to the commission to study historic cemeteries. The comaission shall also forward forthwith to the Commission to study historic cemeteries its finding of fact, if any, together with its action on the application.

45-24.1-5. Avoiding demolition through owner neglect.-A city or town may by ordinance empower city councils or town councils in consultation with the historic district commission to identify structires of historical or architectural value whose deteriorated physical condition endangers the preservation of such structure or its appurtenances. The council shall publish standards for maintenance of properties within 
historic districts. Upon the petition of the historic district com. mission that a historic structure is so deteriorated that its preservation is endangered, the council may establish a reasonable time not less than thirty (30) days within which the owner must begin repairs. If the owner has not begun repairs within the allowed time, the council shall hold a hearing at which the owner may appear and state his or her reasons for not comencing repairs. If the owner does not appear at the hearing or does not comply with the council's orders, the council may cause the required repairs to be made at the expense of the city or town and cause a lien to be placed against the property for repayment.

45-24.1-6. Public meetings.--All meetings of the commission shall be open to the public, and any person or his or her duly constituted representative shall be entitled to appear and be heard on any matter before the commission before it reaches its decision. The commission shall keep a record, which shall be open to public view, of its resolutions, proceedings, findings, decisions, and actions. The commission shall provide notice of its meetings and comply in all respects with the requirements of the open meetings law.

45-24.1-7 Certificate of appropriateness or rejection of plans. The commission shall file with the building official or other duly delegated authority its certificate of appropriateness or rejection of all plans submitted to it for review. No work shall begin until such certificate shall have been filed but in the case of rejection such certificate shall be binding upon the building official or other duly delegated authority, and no permit shall be issued in such case. The failure of the commission to act within forty-five (45) days from the date of application filed with it unless an extension is agreed upon mutually by the applicant and the commission shall be deemed to constitute approval. In the event, however, that the historic district commission shall make a finding of fact that the circumstances of a particular application requires further time for additional study and information than can be obtained within the aforesaid period of forty-five (45) days, then and in the event the commission shall have a period of up to ninety (90) days within which to act upon the application.

45-24.1-7.1 Right of appeal. Any person or persons jointly or severally aggrieved by a decision of the historic district commission shall have the right of appeal concerning the decision to the zoning board and a further right of appeal from the zoning board to the superior court in the same manner provided in Section 45-24-20 and from the superior court to the supreme court by writ of certiorari.

45-24.1-7.2. Scope of review by zoning board. When hearing appeals from commission decisions, the zoning board of review shall not substitute its own judgment for that of the commission, but must consider the issue upon the findings and record of the commission. The zoning board of review shall not reverse a commission decision except on a finding of prejudicial procedural error, clear error, or lack of support by the weight of the evidence in the record. The zoning board of review shall put all decisions on appeal in writing. The zoning board of review shall articulate and explain the reasons and bases of each decision on the record, and the zoning board of review shall send a copy of the decision to the applicant and to the historic district commission. 
(2) Before a property owner may authorize or commence construction, alteration, repair, removal, or demolition affecting the exterior appearance of a structure or its appurtenances within an historic district or affecting an historic cemetery wherever located within a city or town the owner must apply for and receive a certificate of appropriateness from the commission. In applying, the owner must comply with application procedures as established by the commission pursuant to this chapter and the applicable local ordinance. The commission shall require the owner to submit information which is reasonably necessary to evaluate the proposed construction, alteration, repair, removal, or demolition including but not 11mited to plans, drawings, photographs or other information. The owner of the property must obtain a certificate of appropriateness for the project whether or not state law requires that he or she also obtain a permit from the local building official. The building official shall not issue a permit until the commission has granted a certificate of appropriateness.

In the case of an historic cemetery, the owner must comply with all provisions of law and must make suitable and appropriate provisions for the reinterment of any human remains in an established cemetery. Original or existing headstones and markers shall be preserved and installed at the site of the reinterment.

(3) In reviewing plans, the commission shall give consideration to:

(a) The historic and architectural significance of the structure and its appurtenances;

(b) The way in which the structure and its appurtenances contribute to the historical and architectural significance of the district;

(c) The appropriateness of the general design, arrangement, texture, materials, and siting proposed in the plans; and

The commission shall pass only on exterior features of a structure and its appurtenances and shall not consider interior arrangements.

(4) All decisions of the commission shall be in writing. The commission shall articulate and explain the reasons and bases of each decision on a record, and in the case of a decision not to issue a certificate of appropriateness, the commission shall include the bases for its conclusion that the proposed activity would be incongruous with those aspects of the structure, appurtenances, or the district which the commission has determined to be historically or architecturally significant. The commission shall send a copy of the decision to the applicant.

(5) In the case of an application for construction, repair, alteration, removal, or demolition affecting the exterior appearance of a structure, or its appurtenances which the commission deems so valuable to the city, town, state, or nation, that the loss thereof will be a great loss to the city, town, state, or nation, the commission shall endeavor to work out with the owner an economically feasible plan for the preservation of that structure. Unless the commission is satisfied that the retention of the structure constitutes a hazard to public safety which hazard cannot be 
APPENDIX 3: CITY ENABLING LEGISLATION 
Section 500 - Overlay zoning Districts: Overlay zoning districts are hereby established to regulate areas and structures of historical significance, educational and health care institutions, and mixed uses in $R$ zones. These regulations are necessary to meet the purposes set forth in section 100 of this ordinance. The boundaries of the overlay zoning districts are defined in section 102 of this ordinance. These boundaries may be amended in accordance with Article XI of this ordinance. overlay zoning districts are designed to impose supplementary requirements and do not in any manner supercede or replace any requirements of the underlying zone, except where specifically provided for by this ordinance.

Section 501 - Historic District - Purpose: Historic districts are overlay zoning districts which cover designated districts or structures in the city of Providence. The purpose of historic districts is to safeguard the heritage of the city by preserving designated districts and structures of historic or architectural value which reflect elements of Providence's cultural, social, economic, political, and architectural history; to stabilize and improve property values in such districts or designated structures; to maintain and foster civic beauty; to strengthen the economy; and to promote the use of designated districts and structures for the education, pleasure and welfare of the citizens. An historic district may include properties associated with broad patterns, events, and/or people significant in local, state or national history; which embody the distinctive characteristics of a broad range of building types and architectural styles and which may possess high artistic value and/or represent the work of a master builder, architect, landscape architect or other designer; and which lack individual distinction but which add to the Historic District zone's status as a significant and distinguishable sociocultural entity.

501.1 - Historic District Commission - Membership: The Historic District Commission, hereinafter known as the HDC, shall consist of thirteen (13) qualified members who shall reside in the city. Nine (9) members shall be appointed by the Mayor, two (2) members shall be elected by the city council from its councilmanic members to serve for a term ending the first Monday in January, 1975 and thereafter elected for a term of four (4) years, and two (2) members shall be members of the General Assembly elected from the City, one (1) to be appointed from the Senate by the senate Majority Leader and one (1) to be appointed from the House by the speaker.

A) Qualifications: Members of the HDC shall have a demonstrated interest in historic preservation. The appointments may be drawn from but not be limited to the following professions and disciplines: American history, architectural history, landscape design, architecture, archeology, preservation, law, real estate, planning or historic building contracting. Duly organized and existing preservation societies may present to the Mayor lists of qualified citizens to be considered for appointment. 
B) Auxiliary Member: The Mayor shall have the right to name an auxiliary member to the HDC in addition to the regular members, which auxiliary member shall sit as an active member, upon the request of the Chair when and if a regular member of the HDC is unable to serve at any meeting of the HDC.

C) Term: Each member appointed by the Mayor shall serve for a three-year term in accordance with state law and shall be eligible for reappointment. Upon expiration of said term, appointed members shall not continue to serve unless reappointed.

D) Vacancy: In the event of a vacancy on the HDC, the appointing authority shall make an interim appointment to fill the unexpired term(s) of such member(s). Vacancies shall be filled within ninety $(90)$ days.

E) Organization: The HDC shall include a Chair, appointed by the Mayor; and a Vice-Chair elected from its membership. The Department of Planning and Development shall assign staff to work with the HDC.

501.2 - Conduct of Business: The Chair shall preside over all HDC meetings and shall have the right to vote. The Vice-Chair shall, in the case of absence or disability of the chair, perform the duties of the chair. All meetings of the HDC shall be open to the public and any person, organization or duly authorized representative shall be entitled to appear and be heard on any matter before the HDC reaches its decision.

A) Record: The HDC shall keep a record of all resolutions, proceedings, findings, decisions and actions and such record shall be open to the public.

B) Quorum: A quorum shall be necessary for business to be conducted before the HDC. A majority of the duly appointed members shall constitute a quorum.

501.3 - Powers and Duties of the HDC: The HDC shall have the following powers and duties:

A) Requlate Development in Historic Districts: The HDC shall be authorized to regulate the construction, demolition, change in any exterior structure and/or appurtenance within any Historic District identified on the Providence overlay zoning District Maps of the official zoning Map adopted in accordance with this ordinance and identified by section 102.

B) Adoption of Rules: The HDC shall adopt and publish all rules and regulations necessary to carry out its functions under the provisions of this chapter.

C) Adoption of Standards and Guidelines: The HDC shall adopt and publish standards and quidelines as necessary to inform historic district residents, property owners, and the general public of those criteria by which the HDC shall determine whether to is- 
sue a Certificate of Appropriateness. The standards and guidelines adopted for any district located in a D Zone shall take into account the commercial nature of the area, and the intent established in this ordinance. The HDC may adopt different standards and guidelines for any other district. The standards and guidelines shall insure that consideration is given to: the historic and architectural significance of the district, the structure and its appurtenances; the way in which the structure and its appurtenances contribute to the historical and architectural significance of the district; and the appropriateness of the general design, arrangement, texture, materials, and siting proposed in the plans for both new and existing structures and appurtenances. The HDC may incorporate by reference in its rules and regulations such other standards as are appropriate, including, but not limited to the standards and Guidelines for Rehabilitation adopted by the United States Secretary of the Interior. The HDC may from time to time amend its standards as reasonably necessary, and it shall publish all such amendments.

D) Issue Certificate of Appropriateness: The HDC shall be authorized to issue Certificates of Appropriateness for projects that conform to the requirements of this ordinance and the standards and Guidelines adopted by the HDC. A Certificate of Appropriateness may be issued by the HDC indicating approval of plans for alteration, construction, repair, removal or demolition of a structure or appurtenances of a structure within an historic district. Appropriate for the purposes of passing upon an application for a Certificate of Appropriateness means not incongruous with those aspects of the structure, appurtenances, or the district which the HDC has determined to be historically or architecturally significant.

E) Provide Advice to other Agencies: In order to assist the City on matters of historic preservation, the HDC may provide its expertise and advice to agencies of city government as appropriate.

F) Delegation of Authority: The HDC may delegate to the staff authority to issue a certificate of Appropriateness in certain circumstances as defined in accordance with the standards and Guidelines as adopted or by action of the HDC at a public hearing. The staff may not deny a certificate of Appropriateness, but shall refer such action to the HDC for a hearing.

G) Inspection of Work in Progress: The HDC may inspect work in progress after a certificate of Appropriateness has been issued to insure that work is proceeding in accordance with the approval received. If the HDC finds that the work in progress does not conform with the certificate of Appropriateness, the 
HDC shall advise the Director, who shall enforce the requirements of the certificate of Appropriateness in accordance with Article VIII of this ordinance.

501.4 - Certificate of Appropriateness: Before a property owner commences construction, alteration, repair, removal or demolition of any existing structure or its appurtenances within an Historic District overlay zone, the owner must first apply for and receive a Certificate of Appropriateness from the HDC. A Certificate of Appropriateness is necessary whether or not state law or municipal ordinance requires that a building permit be obtained from the Department of Inspection and standards for the work proposed.

A) Application for Certificate of Appropriateness: The HDC shall require the owner to submit information which is reasonably necessary to evaluate the proposed construction, alteration, repair, removal or demolition including but not limited to plans and site plans, drawings and elevations, photographs, or other information.

B) Hearing: The HDC shall hold a public hearing on an application for a certificate of Appropriateness. Notice of such hearing shall be given to all abutting property owners, at least seven (7) days prior to the public meeting, by regular mail. The applicant shall supply the HDC with a list of the names and addresses of all abutting property owners from the most current records of the City Tax Assessor.

C) Filing Fee: An application for a certificate of Appropriateness shall be accompanied by a filing fee as set by the city council which shall be deposited with the city collector and no part of which shall be returned to the applicant.

501.5 - Standards and Guidelines: The HDC shall evaluate all applications in accordance with the criteria established in the Standards and Guidelines adopted in accordance with section 501.3 of this ordinance. The HDC shall act only on exterior features of a structure and its appurtenances. In reviewing an application for a Certificate of Appropriateness, the HDC shall have the power to call in experts to aid in its deliberations, and may incorporate the conclusions of such experts in its decisions.

501.6 -Decisions of the HDC: All decisions of the HDC regarding the issuance of a Certificate of Appropriateness shall be in writing. The HDC shall articulate and explain the reasons and basis of each decision on a record. An application for a certificate of Appropriateness may be approved, denied, or approved with amendment by the HDC. When denying an application for a Certificate of Appropriateness, the HDC shall include the basis for its conclusion that the proposed activity would be incongruous with those aspects of the structure, appurtenances, or the district which the HDC has determined to be historically or architecturaliy 
significant. The HDC shall send a copy of the decision to the applicant and to the Director. The action taken by the HDC shall be binding on the Director. No application shall be denied by the HDC without a hearing.

A) Reapplication: An application for the same petition shall not be heard by the HDC for the period of one year from the date the original petition was denied. The HDC shall have the right to waive this requirement for any petition if a majority of the HDC present at a meeting agree.

B) Ordinary Maintenance: A Certificate of Appropriateness may be issued by the HDC without a pubilc hearing for ordinary maintenance or repair of any structure within an historic district provided that such maintenance or repair does not result in any change of design, type of material, or appearance of the structure or its appurtenances. The HDC may delegate to the staff the authority to approve and issue Certificates of Appropriateness in such circumstances.

501.7 - Failure of the HDC to Act: The failure of the HDC to act within forty-five (45) days from the date of the filing of a completed application shall be deemed to constitute approval unless an extension is agreed upon mutualiy by the applicant and the HDC. In the event that the HDC shall make a written finding of fact within this forty five (45) day period that the circumstances of a particular application requires further time for additional study and information, then the HDC shall have a period of up to ninety (90) days from the date of filing a completed application within which to act upon such application. Nothing in this section shall be construed to prevent the applicant and the HDC from mutually agreeing on an extension beyond this ninety (90) days.

501.8 - Special Criteria for Demolition: In order to preserve the historic fabric of the city, demolition of historic properties shall be discouraged. When reviewing an application for a Certificate of Appropriateness to demolish an historic structure or appurtenance, the HDC shall consider the following criteria, in addition to the provisions of the adopted standards and Guidelines:

A) Structures Valuable to the city: In the case of an application for demolition of any structure, appurtenance or a portion of a structure which the HDC deems so valuable to the city, the state or the nation, that the loss thereof will be a great loss to the City, the state or the nation, the HDC shall endeavor to work out with the owner an economically feasible plan for the preservation of such structure on its present site. The HDC shall issue a Certificate of Appropriateness only if the HDC is satisfied that the retention of such structure constitutes a hazard to public safety which hazard cannot 
be eliminated by economic means available to the owner, including sale of the structure to any purchaser willing to preserve such structure.

B) Structures Valuable for the Period: In the case of an application for demolition of any structure, appurtenance or a portion of a structure deemed to be valuable for the period of architecture which it represents and its importance to the neighborhood within which it exists, the HDC shall issue a Certificate of Appropriateness only if the HDC finds that at least one of the following exists:

1. retention of such structure constitutes a hazard to public safety which hazard cannot be eliminated by economic means available to the owner, including sale of the structure on its present site to any purchaser willing to preserve such structure; or

2. preservation of such structure is a deterrent to a major improvement program which will be of substantial benefit to the community; or

3. preservation of such structure would cause undue or unreasonable financial hardship to the owner, taking into account the financial resources available to the owner including sale of the structure to any purchaser willing to preserve such structure; or

4. preservation of such structure would not be in the interest of the majority of the community.

501.9 - Alternatives to Demolition: The HDC shall assist the owner in identifying and evaluating alternatives to demolition, including sale of the structure on its present site. When considering an application to demolish a structure of historic or architectural value, in addition to any other criteria, the HDC shall consider the following:

A) Whether there is a reasonable likelihood that some person or group other than the current owner is willing to purchase, move and preserve such structure; and

B) Whether the owner has made continuing, bona fide and reasonable efforts to sell the structure to any such purchaser willing to move and preserve such structure.

501.10 - Avoiding Demolition Through Owner Neglect: The city council or its designee, in consultation with the HDC, may identify structures of historical or architectural value whose deteriorated physical condition endangers the preservation of such structure or its appurtenances. The council or its designee shall publish standards for maintenance of properties within historic districts. Upon the petition of the HDC that a historic structure is so deteriorated that its preservation is 
endangered, the council or its designee may establish a reasonable time not less than thirty (30) days within which the owner must begin repairs. If the owner has not begun repairs within the allowed time, the council or its designee shall hold a hearing at which the owner may appear and state his reasons for not commencing repairs. If the owner does not appear at the hearing or does not comply with the council's or its designee's orders, the Council or its designee may cause the roguired repairs to be made at the expense of the city and cause a. lien to be placed against the property for repayment. The HDC shall cooperate with and assist the city Council or its designee in exercising the provisions of this section.

501.11 - Appeais: "A person or person's jointly or severally aggrieved by a decision of the HDC shall have the right to appeal the decision to the Board. When hearing appeals from HDC decisions, the Board shall not substitute its own judgement for that of the HDC, but must consider the issue upon the findings and record of the HDC. The Board shall not reverse an HDC decision except on a finding of prejudicial procedural error, clear error, or lack of support by the weight of the evidence in the record. The Board shall file a written decision explaining the basis of each decision for the record, and the Board shall send a copy of the decision to the applicant and to the HDC. The filing fee and the filing procedure for an appeal of the decision of the HDC shall be the same as that for an appeal of the decision of the Director.

501.12 - Enforcement: This regulation shall be enforced in accordance with Article VIII of this ordinance. 
APPENDIX 4: INVENTORY OF ARCHITECTURAL STYLES 


\section{FEDERAL 1785-1830}

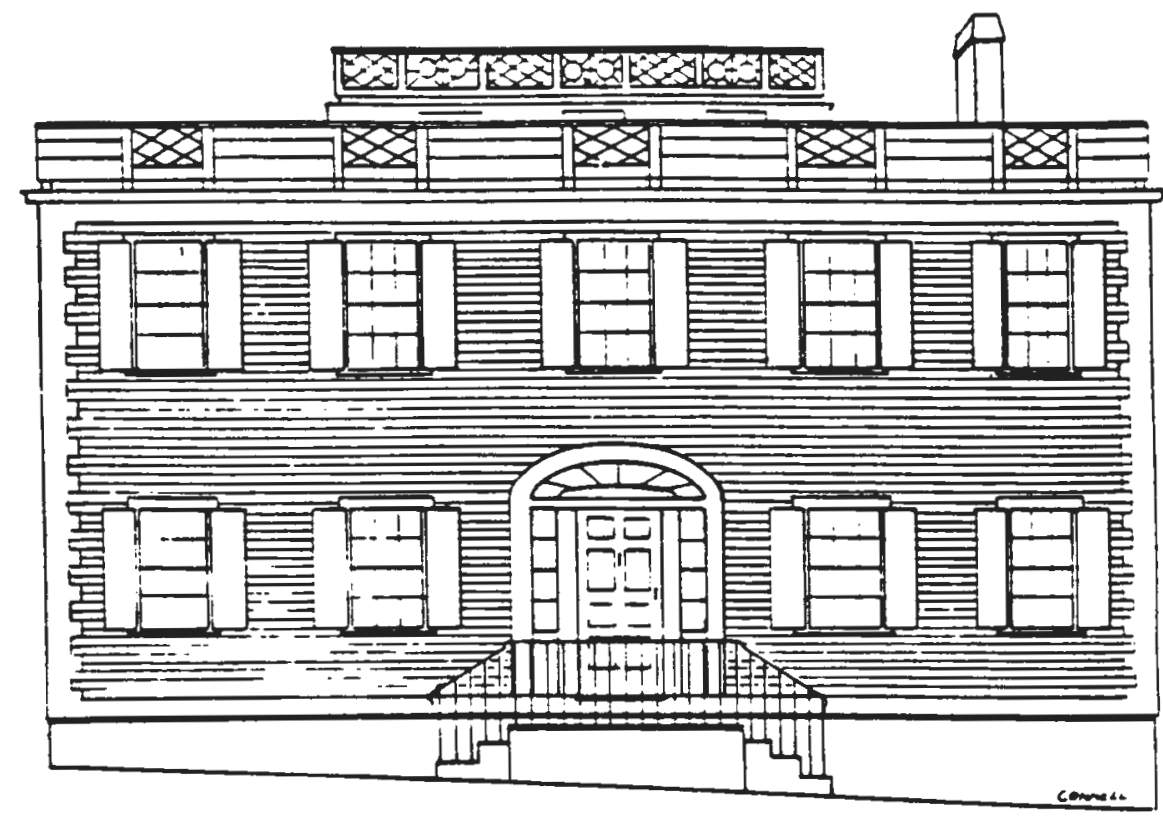

Taking its name from the newly instituted federal form of government, this style became popular shortly after the Revolutionary war. often referred to as the Adam style, it first developed in England and was named for three brothers whose designs popularized the style.

Generally, a federal style house is rectangular shaped and tall, narrow windows with $6 / 6$ sash are symmetrically arranged around a central doorway. The Door is ususally the central focus of federal style house. It was common to flank the door with slender, classically detailed columns or pilasters. These would be topped with a flat entabulature to form a porch. other features often found on a federal style home are semi-elilptical fanlights and strips of small paneled glass whlch frame the door.

The exterior surface was clapboard and typically painted soft beige, off white, pale yellow or green.

Source: Text and photo is from The Block Island Historic District Commission Guidelines for Bullding in the Historic District. 


\section{Greek Revival $1820-1850$}

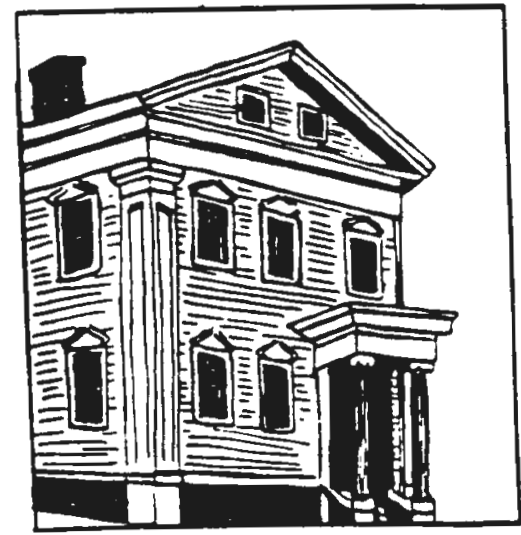

The Greek Revival style embodied the ideals of the emerging nation in the early 1800's. It is based upon Greek and Roman temple architecture, which early designers identified with the spirit of ancient democratic philosophies. The Greek Revival style was not transplanted from Europe and is therefore considered the first "American" style of architecture. During the 1830 's and 1840's it was the most prevalent style in America.

The most common mistake made in renovations of the Greek Revival style is the removal or covering of the corner pilasters during re-siding. This results in a "temple" facade without the supporting "columns". A six inch corner board, typical for many styles, is not appropriate in a Greek Revival facade. The entablature or horizontal trim on top of the pilasters, commonly called the "bed", can either be broken or can span the space between the two pilasters. This bed is necessary if the pilasters are to appear to be providing support. Distinctive features of the style are six-over-six light window sash, two-/or four-panel doors, heavy plain trim, and earth tone colors to mimic marble or stone. Some Greek Revival buildings were even painted with paint having sand mixed in to render the look and texture of real stone.

Source: Text is from The Smith Hill Architecutral Workbook,
while the photo is from Providence Preservation while the photo is from Providence Preservation society's
Broadway:A victorian Boulevard. 
Gothlc Revlval

1850-1870

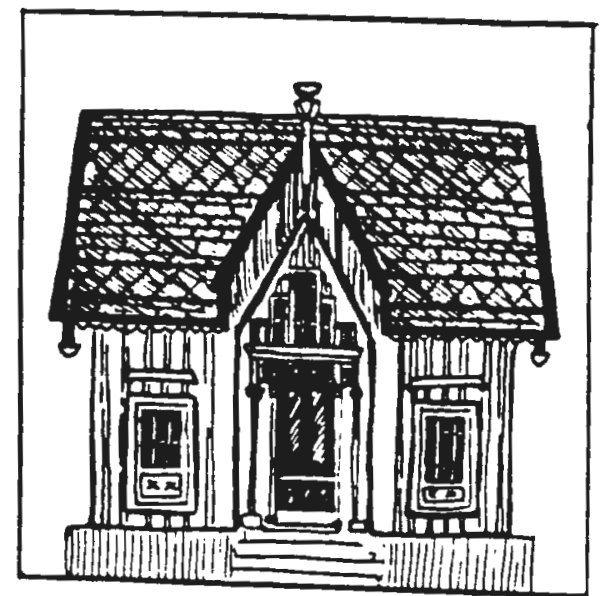

Born from romantic longings to embrace features from medieval cathedrals, these houses abound with symbolic references to the former Gothic age; pointed arches, window tracery, lancet or easement windows with diamond-shaped panes. Expect to see an irregular silhouette composed of tall intersecting gables, finials, decorative chimney pots, and, on grander houses, square or octagonal towers or turrets. The plan may be boxlike, recalling the symmetrical arrangement of its classical forebears, or asymmetrical with side wings. Spacious verandas nearly always grace these homes. Gothlc revival houses stress vertical features:pointed arches, slender windows, peaked dormers, steeply pitched roofs, and perpendicular board and batten siding.

Source: Text is from The Block Island Historic District Commission Guldelines for Bullding in the Historic District, while the photo is from Providence Preservation society's Broadway: A Victorian Boulevard. 


\section{Italianate $1850-1890$}

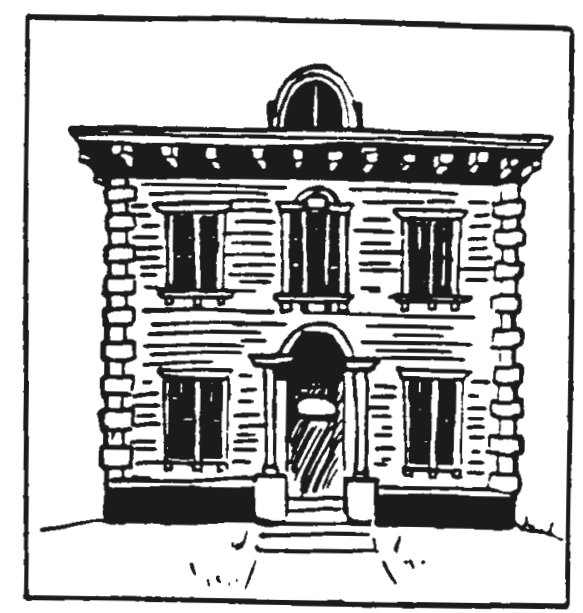

In the 1850's, the Italianate style became the most widely used style in America. Based upon Italian villas, Renaissance palaces, and rural Italian architecture, this style is most recognizable by its repetitive brackets under wide projecting eaves and over windows and doors.

Many residential structures built in the late $1840^{\prime}$ 's and early 1850's are a combination of the earlier Greek Revival style with new Italianate elements. The popularity of this flexible style was so great that Italianate detailing spread into the next architectural period called the Mansard or Second Empire style, characterized by steep mansard roofs and numerous dormer windows. Distinctive features of Italianate buildings besides their brackets and window/door hoods are their unbalanced or asymmetrical massing, bay windows, two-overtwo light window sash, four-panel doors or double two-panel doors with transom. Early Italianate houses retained the Greekrevival influence of six-over-six light sash, simple sidelights and transom doorways with a bracketed hood or portico. Porticoes grew to become porches situated asymmetrically to one side, accessible from a parlor by large, sometimes double-doors. Preferred colors were originally earth-tones, but the pallette grew darker, with body and trim colors in close hues.

Source: Text is from while the photo is Broadway: A Victorian

The Smith Hill Architecutral Workbook, from Providence Preservation society's 


\section{Mansard $1860-1880$}

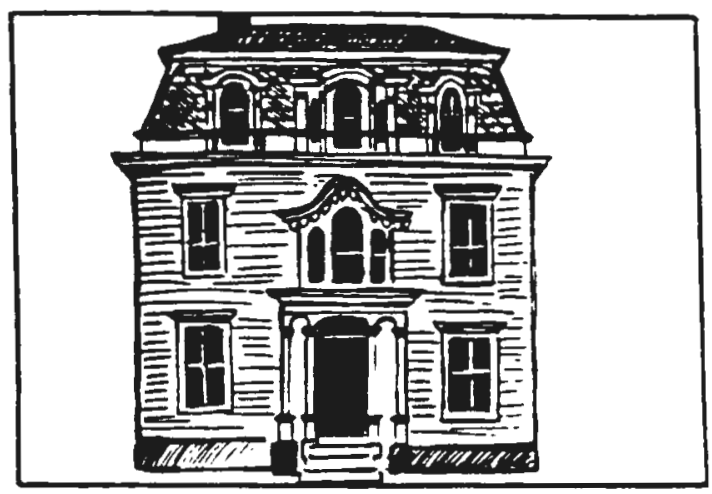

Also known as the "Second Empire" style, Mansard residences with their characteristic double-pitched roofs were popular in Providence during the 1860's and 70's. Many earlier houses were "modernized" with Mansard roofs during this time. Most of the distinctive characteristics of the Mansard style come from the Italianate. Other characteristics include brackets, bay windows with two-over-two light and sometimes even one-over-one light sash, semi-circular arch-top or segmental head windows, and formal double-doors with etched glass. Colors became bolder in this Victorian style; trim colors often contrasted with base colors.

In our own time, false mansard roofs have again become popular, especially in the commercial types of building rehabilitation projects. They should be avoided, as they are generally awkward, poorly proportioned, and detract from the overall scale of the street.

Source: Text is from The Smith Hill Architecutral Workbook, while the photo is from Providence Preservation society's Broadway: A Victorian Boulevard. 


\section{Stlck Style}

1875-1885

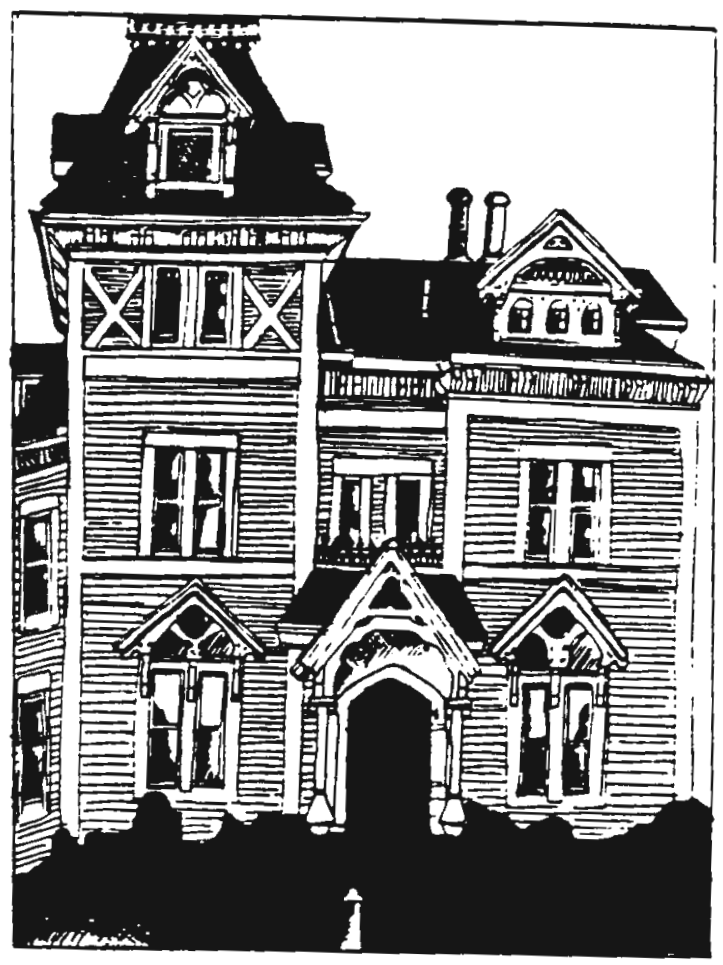

Stick Style, 478 Broadway

Informal and relaxed, stick style homes have a democratic air. Distinctive skeletal stick work gives this style its name. Superimposed on the wood clapboard siding, the exposed framing suggests on the outside the inner structural balloon framework of the house. Vertical and horizontal thin boards, intersecting at right angles, punctuate the walls, gables and dormers. You will also find X-shaped crosspieces and diagonal stlckwork resembling halftimbering. Essentially non-structural, the projecting stickwork enhances the house by creating decorative shadows on the surface. other adornments on these woods tend to be simple and angular, too, largely confined to the caves and porches. In most examples of this style the window placement is regular, but the fumble of gables, dormers, and chimneys forms an lrregular slihouette.

Source: Text is from The Block Island Historic District Commission Guidelines for Building in the Historic District, while the photo is from Providence Preservation society's Broadway: A Victorian Boulevard. 


\section{Queen Anne $\quad 1890-1910$}

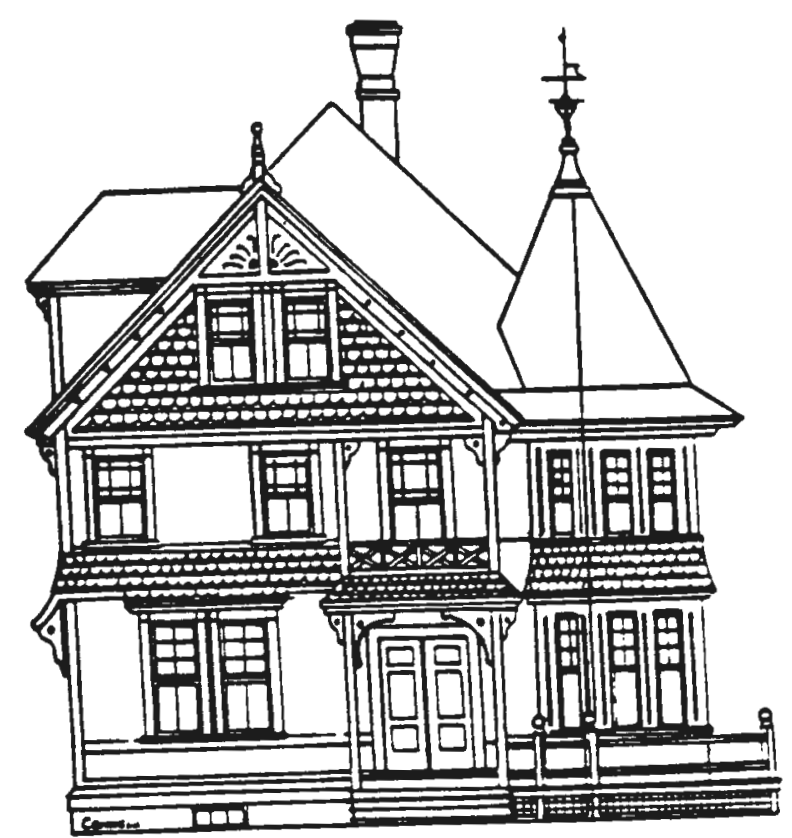

The Queen Anne style was popular in Providence during the last quarter of the nineteenth century. Based in part on the English country house, it represented a renewed interest in the picturesque qualities of the past and a revival of European classical and American colonial details. Distinctive characteristics of this style include irregular rooflines broken by gables and dormers, corner towers, and turrets. Surface detailing was quite varied, combining clapboards, brick, or stone with decorated shingles. There was a strong emphasis on the horizontal divisions of floors. Porches were an integral design element. Window sashes were varied but usually characterized by either one-over-one light or a variety of patterns over one light. Stained and colored glass set in lead or a wood sash patterns were extremely popular. Colors became daring, often combining three or four colors to help accentuate the variety of detail.

Source: Text is from The Smith Hill Architecutral Workbook, while the photo is from the Historic Colors Workbook. 


\section{Three Decker $1890-1930$}

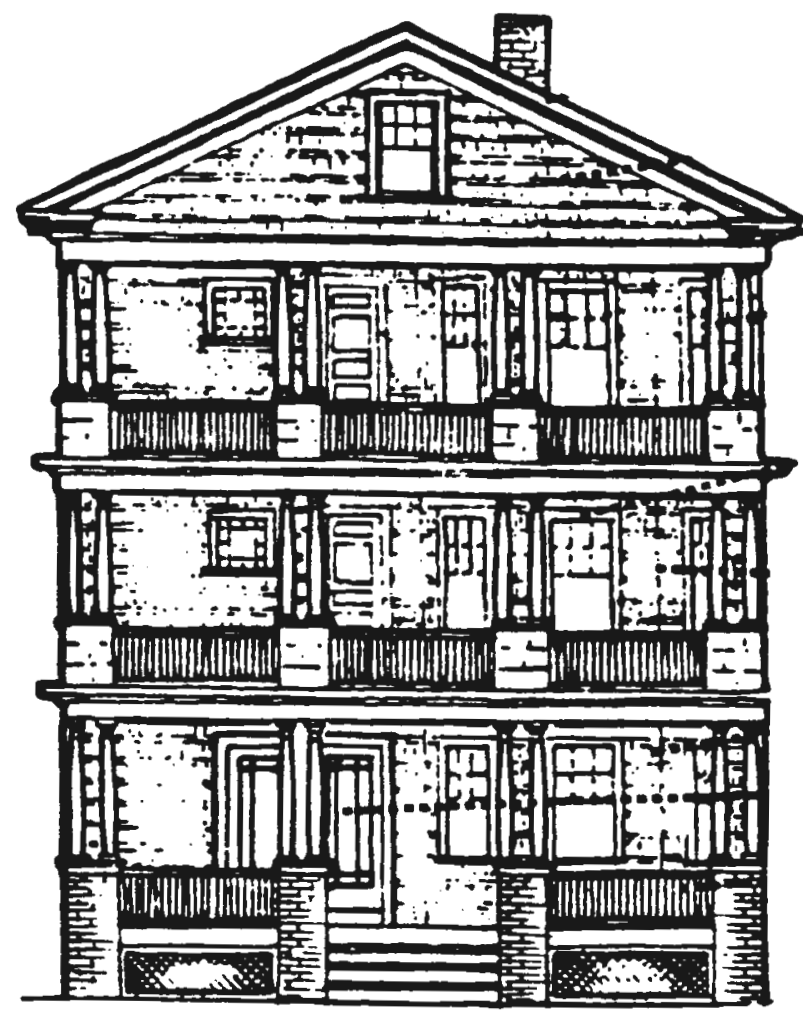

The three-story building, with one apartment on each floor and porches covering the front of the building, prolifereated in New England between 1890 and 1930 as the need for housing dramatically increased. While the outside appearance of the three decker followed the architectural fashions of the Queen Anne and later Colonial Revival style, its basic form underwent little change, for it is a building type rather than a particular style. Some of the three deckers built in the Smith Hill area on Jewett Street and Oakland Avenue represent a trend towards Greek and Roman classical detailing, with two and threestory column porches and facades. The classical detailing was later simplified and large classical columns were replaced by one-story double columns supporting front porches. Triple deckers had one-over-one light sash, two-over-one light sash or six-over-one light sash, and simple utilitarian doorways. Trim colors were lighter than the base color; green and red sash and doors contrasted with the body.

Source: Text and photo is from the smith Hill Archltectural
workbook. 
BUNGALOW 1910.1930

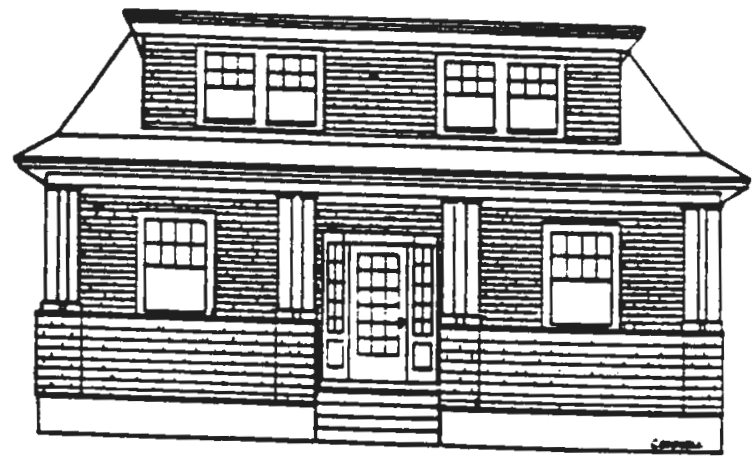

Bungalows are picturesque one-story houses with a low overhanging roof and broad porches. often combining "natural" materials or fieldstone, shingles, and stucco, they were usually left to weather unpainted or stained to darken the wood.

Bungalows, built throughout the country primarily from 1890 to 1920, were loosely described as any cottage like dwelling, informal in plan, elevation, and detall. They answered a widespread need for simpler residences brought on by economic setbacks of the $1890^{\prime} \mathrm{s}$. The Bungalow began in California, evolving from the craftsmen heritage, and quickly spread to other parts of the country where it was adapted to a multitude of different styles. Despite these variations, the Bungalow had certain basic characteristics. its lines were low and simple with wide projecting roofs. It had at most two stories, but usually one, large porches (verandas) and was made with materials that suggested a $k$ ind of coziness.

The Bungalow style was so popular after 1905 that it became the first style to be built in quantity by the contractor-builder. By 1910, throughout all of California and most other parts of the country, street after street was lined with differently styled bungalows.

Source: Text and photo is from The Block Island Historic District Commission Guidelines for Building in the Historic District. 
APPENDIX 5: AGENCY SURVEY FORM 


\section{HISTORIC DISTRICT COMISSION HANDBOOK SURVEY}

1. Name or Organization:

2. Address :

3. Phone \#:

4. Name of Executive Director:

5. Founding date of organization:

6. Please indicate the goals, purpose or mission statement of your agency:

7. Please indicate the total number of persons working for your agency:

8. Please indicate your total number of volunteer workers:

9. Please list and describe programs sponsored or administered by your agency relating to the preservation, repair and enhancement of architecturally and or historically signiflcant bulldings: 
10. Please attach coples of brochures, pamphlets, and /or newsletters that describe these programs.

11. Please indicate the total number of persons that sought help from your agency in 1991:

12. Please indicate the total number of persons that recelved help Erom your agency in 1991:

13. May we contact you at a later date for additional information, if needed?

14. How do you percelve the Providence Historic District Commission? How would you change or improve the Commission?

15. Do you think that preservation activities in the city of Providence can be improved? If so, how would you improve them?

16. Attached is a list of organizations which recelved a copy of this survey. Would you please review this list, and inform us if we have missed any agency that you feel has had or will have a significant impact upon historic preservation in the city, particularly with respect to the city's local historic districts?

Also include the name of the executive director and the malling address for these agencles. 
1. Cholce: Cholce Housing Opportunity Information Center

2. The Elmwood Foundation for Architectural and Historical Preservation.

3. The Elmwood Nelghborhood Housing Services

4. The Providence Preservation society

5. The Providence Preservation Revolving Fund

6. Rhode Island Historic Preservation Commission

7. Stop Wasting Abandoned Property (S.W.A.P.)

8. The Providence Foundation

9. The Smith H1ll Neighborhood Association

10. West Broadway Homeowners Assoclation 
BIBIIOGRAPHY

166 


\section{BIBLIOGRAPEY}

Arkansas Historic Preservation Program 1986. The Procedural Handbook for Local Historic District Commissions, state of Arkansas : Arkansas.

Block Island Historic District Commission, 1987. Guidelines For Building in the Historic District, Town of Block Island:Rhode Island.

Boston University Preservation Studies Colloquium, 1987 . South Providence and Elmwood Conservation Strategies, boston University: Massachusetts.

Bowsher, Alice Meriwether, 1983. Design Review in Historic Districts, National Trust for Historic Preservation: District of Columbia.

Buckhurst, Fish, Hutton and Katz Inc.1991. A Plan For Preservation, City of Providence:Rhode Island.

City Council Committee on Ordinances, 1991. The Proposed North Elmwood Historic District Public Hearing Transcript,

Allied Court Reporters:Rhode Island.

City of Providence 1987. Certified Local Government Report Annual Report, City of Providence:Rhode Island.

City of Providence 1988. Certified Local Government Report Annual Report, City of Providence:Rhode Island.

City of Providence 1989. Certified Local Government Report Annual Report, City of Providence:Rhode Island.

City of Providence 1990. Certified Local Government Report Annual Report, City of Providence:Rhode Island.

City of Providence, 1991. Providence 2000: The Comprehensive Plan, City of Providence:Rhode Island.

City of Providence, 1981. The Smith Hill Architectural Workbook, City of Providence:Rhode Island.

City of Providence, 1991. Zoning Ordinance, City of Providence:Rhode Island.

Duerksen, Christopher J., 1983. A Handbook on Historic Preservation Law, The National Center for Preservation Law:District of Columbia.

Keune, Russell V., 1974. A Guide to Delineating the Edges of 
Historic Districts, National Trust for Historic Preservation:District of Columbia.

New Bedford Historical Commission. Guidelines for the Bedford Landing-Waterfront Historic District, Bedford Historical Commission:Massachusetts.

Providence City Plan Commission, 1967. College Hill: A Demonstration Study of Historic Area Renewal, City of Providence: Rhode Island.

Providence Preservation Society 1982. The Armory District:Harmonious Streetscapes, PPS:Rhode Island.

Providence Preservation Society 1983. Broadway: A Victorian Boulevard, PPS:Rhode Island.

Providence Preservation Society 1983. Elmwood:A Victorian Neighborhood, PRS:Rhode Island.

Reynolds, Judith, 1982. Historic Properties: Preservation and the Valuation process American Institute of Real Estate Appraisers:Illinois.

State of Rhode Island, Rhode Island Historical Preservation Commission, 1986. Providence: A Citywide Survey of Historical Resources Statewide Historical Preservation Report, $p-p-7$, RIHPC:Rhode Island.

State of Rhode Island, Rhode Island Historical Preservation Commission, National Register of Historic Places Inventory Nomination Form for the CBD, RIPHC:Rhode Island.

State of Rhode Island, Rhode Island Historical Preservation Commission, - National Reqister of Historic Places Inventory Nomination Form for the Armory-Broadway District RIPHC: Rhode Island.

State of Rhode Island, Rhode Island Historical Preservation Commission, - National Register of Historic Places Inventory Nomination Form for the Elmwood District RIPHC:Rhode Island.

State of Rhode Island, Rhode Island Historical Preservation Commission, - National Reqister of Historic Places Inventory Nomination Form for the stimson Avenue District RIPHC:Rhode Island.

Special Committee on Historic Preservation, United States Conference of Mayors, 1964. With Heritage So Rich, National Trust for Historic Preservation:District of Columbia. 
State of Ohio, 1981. Opportunities for Bringing People Back Downtown, State of Ohio:Ohio.

The Providence Historic District Commission 1992. Standards and Guidelines for the Armory, Broadway, College Hill, South Elmwood and Stimson Avenue Historic Districts, City of Providence: Rhode Island.

The Providence Historic District Commission 1992. Rules and Requlations, City of Providence:Rhode Island.

The Uptown Oxford Historic and Architectural Preservation Commission, 1989. The Historic and Architectural Preservation Commission:Design quidelines Uptown Oxford Historic District, City of oxford:Ohio.

Ziegler, Arthur P., 1974. Historic Preservation in Inner City Areas: A Manual of Practice, Ober Park Associates:Pennsylvania.

Personal Interviews

Kathryn J. Cavanaugh, Assistant City Planner for Preservation. 1992. Personal Interviews. Providence, Rhode Island. JanuaryApril.

Karen Jessup, Chairperson Providence Historic District Commission 1992. Personal Interviews. Providence, Rhode Island. April 6.

Patricia Nolan, Member of Providence Historic District Commission and City Council Representative 1992. Personal Interviews. Providence, Rhode Island. April 11.

Arnold Robinson, Assistant Director Providence Preservation Society, 1992. Personal Interviews. Providence, Rhode Island. February.

Ken Schadegge, The Elmwood Foundation for Architectural and Historical Preservation, 1992. Personal Interview. Providence, Rhode Island.

Clark Schoettle, The Providence Preservation Society Revolving Fund, Inc., 1992. Personal Interview. Providence, Rhode Island.

Mary Turkel, Preservation Planner, The providence Historic District Commission, 1992. Personal Interview. Providence, Rhode Island. 